\title{
COVID-19 PANDEMIC: RISK ASSESSMENT AND THE LACK OF BASIC PREVENTIVE MEASURES AFTER THREE MONTHS OF RE-OPENING
}

\author{
Emine ATASOYLU1 ${ }^{*}$, Işll Nurdan IŞIK² \\ ${ }^{1}$ Eastern Mediterranean University, Faculty of Engineering, Department of Industrial Engineering, North Cyprus \\ ORCID No: http://orcid.org/0000-0003-0828-328X \\ 2 Eastern Mediterranean University, Faculty of Engineering, Department of Industrial Engineering, North Cyprus \\ ORCID No: http://orcid.org/0000-0001-8750-6319
}

\section{Keywords}

Covid-19

SARS CoV-2

Risk assessment

Preventive measures

Ergonomics

\begin{abstract}
COVID-19 was announced to be a pandemic by the World Health Organization in March 2020. A lockdown in most countries throughout the world took place to break the chain of its spread. In late May of the same year re-opening started with new regulations to protect people from this new SARS-CoV-2 hazard. The goal of this study was to evaluate the degree to which COVID related occupational preventive measures were being taken in North Cyprus (NC) at the time of the COVID-19 Pandemic. A checklist was prepared and applied to different industries in NC to identify the observable measures taken. A risk assessment (RA) was conducted in a private hospital using the online interactive risk assessment (OiRA) tool of OSHA-EU. Mask usage and alcohol-based disinfectants at only the main entrances (54.55\%) were the most important measures taken. The RA conducted in a hospital setting where there was a lot of people traffic, mostly patients, entering and exiting, showed that the hospital was not well prepared for the new SARS-CoV-2 occupational risk factor. Poor workplace management was identified. Even the most important, basic general measures to reduce physical contact and therefore the risk of infection had not been adopted.
\end{abstract}

\section{COVID-19 PANDEMİĞí: RİSK DEĞERLENDİRMESİ VE ÜÇ AYLIK YENIDEN AÇILMADAN SONRA TEMEL ÖNLEYICII TEDBİRLERİN OLMAMASI}

\begin{tabular}{l} 
Anahtar Kelimeler \\
\hline Covid-19 \\
SARS CoV-2 \\
Risk değerlendirmesi \\
Önleyici Tedbirler \\
Ergonomi
\end{tabular}

\begin{abstract}
Öz
COVID-19, Mart 2020'de Dünya Sağlık Örgütü tarafından bir salgın olarak ilan edildi. Yayılma zincirini kırmak için dünyadaki çoğu ülkede bir kapanma gerçeklești. Aynı yılın mayıs ayı sonlarında, insanları SARS-CoV-2 tehlikesinden korumak için yeni düzenlemelerle yeniden açılış başladı. Bu çalışmanın amacı, COVID-19 Pandemisi sırasında Kuzey Kıbrıs'ta COVID ile ilgili mesleki önleyici tedbirlerin ne ölçüde alındığını değerlendirmektir. Alınan gözlemlenebilir önlemleri belirlemek için Kuzey Kıbrıs'taki farklı endüstrilere bir kontrol listesi hazırlanmış ve uygulanmıştır. OSHAEU'nun çevrimiçi etkileşimli risk değerlendirme (OiRA) aracı kullanılarak özel bir hastanede bir risk değerlendirmesi (RD) gerçekleștirildi. Sadece ana girişlerde maske kullanımı ve alkol bazlı dezenfektanlar $(\% 54,55)$ alınan en önemli tedbirlerdi. Insan trafiğinin yoğun olduğu bir hastane ortamında (çoğunlukla hasta) yürütülen RD, hastanenin yeni SARS-CoV-2 mesleki risk faktörü için iyi hazırlanmadığını gösterdi. İsyeri yönetiminin iyi olmadığı, fiziksel teması ve dolayısıla enfeksiyon riskini azaltmak için en önemli, temel genel önlemlerin bile benimsenmediği görülmüștür.
\end{abstract}

\begin{tabular}{llll}
\hline Araştırma Makalesi & \multicolumn{3}{l}{ Research Article } \\
Başvuru Tarihi & $: 05.04 .2021$ & Submission Date & $: 05.04 .2021$ \\
Kabul Tarihi & $: 10.08 .2021$ & Accepted Date & $: 10.08 .2021$ \\
\hline
\end{tabular}




\section{Introduction}

A new strain of coronavirus, a disease causing virus from the same family of Severe Acute Respiratory Syndrome (SARS) was first seen in the Wuhan City of China in December 2019 (Abed Alah et al., 2020) and was later named as SARS CoV-2. The virus unexpectedly and rapidly spread to other countries causing very serious illness. The coronavirus disease: COVID-19, caused by the SARS CoV-2 virus, was announced as a pandemic by the World Health Organization (WHO) on March 11, 2020 (WHO, $2020 \mathrm{~b})$. The name of the disease, COVID-19, was announced by the WHO on the $11^{\text {th }}$ of February 2020 (WHO, 2020a) where CO stands for corona, VI for virus and $\mathrm{D}$ for disease.

The virus is transmitted by respiratory droplets of an infected person which can take place as simple as by talking to that person at a close distance or touching a contaminated surface. The spread of CoV-2 SARS is similar to the spread of other viruses which is by exposure to respiratory droplets generated through talking, coughing and sneezing.

There was no specific treatment for COVID-19 or vaccine to prevent infection. Research and clinical trials are ongoing. Given the rapid spread of the virus worldwide most countries went into total lockdown to prevent its spread by breaking the chain. Subsequently, with the lifting of restrictions most businesses started re-opening in late May or June 2020.

Various preventive measures were continuously announced by reputable organizations worldwide such as the WHO, Centers for Disease Control (CDC) in the U.S., US Occupational Safety and Health Administration (OSHA), National Institute for Occupational Safety and Health (NIOSH), and the European Agency for Occupational Safety and Health (EU-OSHA).

The government policy makers followed the developments and recommendations and tried to make quick decisions about the mandatory local regulations to prevent the spread. These new rules and regulations became more important after businesses re-opened in an attempt to normalize life, as government officials encouraged adapting to the "new normal" or "learning to live with the deadly COVID-19."

These were difficult times for every human being but especially for the health workers and the people defined as being at higher risk of exposure to the virus. The CDC regularly updated the list of people at increased risk based on the most up to date research and evidence and specified "older adults" and "people with severe medical conditions" as the most at risk group (CDC, 2020). The risk increases as people age, and those with underlying medical conditions and advancing age the risk of not being able to recover from COVID also increases.

The North Cyprus Government Council of Ministers decided on sector wise specific regulations (North Cyprus, 2020b) as part of OSH practices with the aim of protecting the public following the re-opening phase. The new rules were announced as mandatory OSH practices for complying with employer obligations stated in NC OSH law 35/2008 under article 6, and were described as "precautions to be taken against corona virus in the workplace." The labor office announced the general precautions with the statement "current emergency plans and RA documents should be revised taking the COVID-19 outbreak into consideration"(North Cyprus, 2020a). This reminded every company of the periodic need for RAs and the need to be prepared to review these documents with government officials whenever necessary.

The general precautions document included rules to follow on hygiene practices including disinfecting the work place, and hand washing, on the maximum number of customers/people allowed to enter the workplace at any given time, record keeping of information on all who entered the workplace (such as name-surname, phone number, time of the day etc.), measuring body temperature at entrance, providing air circulation, usage of proper personal protective equipment (PPE), social distancing, and having flexible work schedules for those employees in the risk group such as those with chronic heart disease, hypertension, high blood sugar, and those over the age of 65 . All of these rules published and posted under the ministry web site were set to protect people at work as well as the general public. This is also the general aim of all OSH laws, rules and regulations.

Complying with rules and taking proper timely precautions are very important for controlling the spread of the disease (Bruinen de Bruin et al., 2020), keeping the transmissibility-Ro at the recommended level (below 1), reducing mortality and not overwhelming the healthcare system (Petersen and Gökengin, 2020).

The objective of this study was to evaluate the degree to which COVID related occupational preventive measures were being taken in NC during the COVID19 Pandemic.

\section{Materials and Methods}

This study is an observational field study using a cross sectional study design. Additionally, a RA was performed at one of the observed sites using a validated tool. 
In the first part of this study a checklist was prepared (Appendix) for observing preventive measures taken by different industries in Famagusta after 3 months of re-opening following the covid-19 lockdown in North Cyprus. The sites visited were selected to be representative and included a: bank, book and stationary store, construction firm main office, electronics retail store, florist, government office, hardware store, private hospital, private university, small neighborhood market and a supermarket. Each workplace was observed daily for eleven days starting from the 25th of August 2020 (3 months after the lockdown ended). The collected data was analysed using basic descriptive statistics with Microsoft Excel software.

In the second part of this study the OiRA tool (European Agency for Safety and Health at Work, 2020) developed by the European Agency for Safety and Health at Work (OSHA-EU) was used to conduct a RA considering the new hazard SARS-CoV-2 virus in a private hospital setting. With this tool, the status of occupational preventive measures was evaluated, and the missing essential components for proper protection from the virus identified. A conversation with a medical doctor from the leadership team confirmed the absence of a COVID-19 coordinator and an emergency communication plan. The COVID19 package of this web-based tool includes the following 9 categories.

1. General organizational measures and procedures: including measures such as having a coordinator for COVID-19, providing information flow about measures to staff, and having an emergency response plan.

2. Workplace management: taking measures to avoid physical contact with and between workers, organizing one way pedestrian flow wherever possible, rearranging common areas and cleaning facilities, measures to reduce the risk of infection in reception areas, toilets, and providing a sufficient number of waste bins with lids.

3. Encouraging and enabling hygienic behavior: making sure staff understand the importance of proper hand hygiene and use of masks, providing appropriate facilities for hand hygiene, encouraging staff to stay at home and isolate themselves if they feel any symptoms of illness.

4. Commuting to work and local errands or travel: encouraging staff to not use public transport, to use their own car, to not travel in the same car with others, to wear a mask and plan the physical distancing whenever it is necessary to travel with others.
5. Teleworking: Encouraging staff to do work from a distance by providing online solutions and ergonomic recommendations, having an approach to communicate with staff working online, and caring for their psychosocial needs.

6. Externals on site: revising the involvement of external service providers in the company and applying procedures, taking preventive measures, and giving special attention by frequently cleaning the areas they use in order to reduce the risk of infection due to these services.

7. Reopening premises after business closure: Not applicable to our study site since the hospital was not closed during general lockdown.

8. Company holding meetings or events with externals: measures needed to be taken when meetings take place with externals including arranging distance, informing participants about the rules and gathering contact information.

9. Business trips: Employees at higher risk shouldn't be sent on business trips, necessary measures should be provided for those who are traveling and if the trip is to a location where COVID-19 cases are increasing, employers should require employees to not come to work and selfisolate for 14 days.

10. and space for any other applicable field added by the user based on the workplace and country regulations.

Under each category, questions, in the form of checklists, are included to evaluate the current situation and identify any missing measures. Space is provided for the user to include additional measures. The reaserchers visited the hospital everyday until all questions were answered and no new hazardous conditions were identified. In order to observe different situations random times of the day were selected on different days and observations were made within a three hour time period. The collected data were entered into the online tool. The report generated by the tool specified various hazardous situations with their corresponding risk level (rated as High, Medium or Low), the measures which need to be taken, space for specifying those in the company responsible for taking action, the recommended start and end date for these actions, the status (either as planned, in process or implemented), and other comments if necessary. In this study the only fields included were the category of hazards, current situation, risk level of each hazard as generated by OiRA, and the recommended 
measures which are the measures that have to be taken to reduce the risk of being infected from SARSCoV-2. The responsible person in the workplace and the time-frame for the preventive measure to be put in place is not included since the study aim is to identify the extend to which the necessary measures are being taken, and not the implementation of the measures. Immediate corrective action is necessary for risks rated as high followed by medium and low risk levels. The RA was completed in 19 days in September 2020.

Permission was granted by employers or employer representatives prior to including the workplace in the study. An ethics board review was not deemed necessary in the absence of human subjects.

\section{Results}

Table 1 shows mask usage in various sectors, monitoring the first 10 customers or employees seen entering the premises. In general, mask usage was good after it was deemed a requirement. It was observed that mask usage among customers was better than that of employees. On average $86.4 \%$ of customers were wearing masks, and $75.50 \%$ of these were noted to be wearing their masks properly. In comparison, on average $77.80 \%$ of employees were noted to be using masks, and only $61.20 \%$ of these were wearing their masks properly. Improper mask usage was defined as not covering both nose and mouth. The checklist results of observable measures are included in Table 2. The results of the hospital RA conducted with the OiRA tool is summarized in Table 3.

\section{Discussion}

Companies in North Cyprus are not applying most of the basic measures considered by reputable organizations to be effective for preventing infection with SARS CoV-2. This finding was expected, since companies are not used to conducting RAs due to the lack of government enforcement of OSH laws (Atasoylu and Ișik, 2017). The observational component of this study shows that companies are far from protecting the safety and health of employees or the general public.

Mask usage was the main precaution taken after 3 months of workplace re-opening which was likely due to recent government enforcement of mask usage. The absence of a culture of safety (Gökçe et al., 2020) and lack of RAs contributed to other precautions not being in place. The results show that employees, customers or other members of the public entering workplaces are in general wearing masks, however not all were wearing their masks properly. Mask usage was proper in $61.20 \%$ of employees and $75.5 \%$ of the customers/public. Among the study sites, the Bank and Government Office were the only places that considered the total allowable number of people to enter based on the size (square meters) of the workplace. They paid attention to maintaining a distance of 2 meters between customers and work stations. Based on our observations, there was no planned safe distance maintained for people waiting outside to enter the workplace. Those waiting stood very close to each other and most were not wearing masks properly. Masks were observed on the chins of those waiting or only covering the mouth, leaving the nose uncovered. No signs or floor markings were noted to guide or remind them that they should be at least two meters away from each other while waiting to enter. The application of protective measures within but not outside the workplace studied seemed to be more for the protection of staff instead of the public. Body temperature measurements were being taken at the entrance of $27.27 \%$ of workplaces. Most measurements of these devices were inaccurate due to not being calibrated and/or not being suitable for day long measurements. The attempt at making these measurements appeared to be a formality to meet a requirement rather than attention being paid to its accuracy or proper use to inform preventive measures. The new government regulations include record keeping of the people entering the premises including their contact details, but only $18 \%$ of the companies studied were doing so. Among these, only one took information of every individual entering, while the others only took the name, surname, and contact details of only $50 \%$ of those entering. This makes it impossible to do contact tracing and follow all those that potentially could be infected if any cases arose. It appeared that record keeping too was being done to show compliance with regulations in case there was a government inspection. Very simple and low-cost measures like providing a plastic shield at the information and cashier's desks, social distancing floor markings, and one-way pedestrian flow were not considered. A very small number of companies (plastic shield: $18.18 \%$, floor markings: $18.18 \%$ and one way pedestrian flow: $0 \%$ ) were taking these measures.

The measures included in the checklist of the first part of this study while easy to apply, low cost and with high potential impact leading to effective protection, were not in place. Future studies can include investigating the reasons behind not taking effective preventive measures such as those included in the checklist and identifying why measures were not taken unless enforced by the government. Mask usage increased after the government announced the institution of fines if masks were not worn. After this government enforcement, workplaces started asking people to wear a mask at entry. Overall, disinfectant availability before entering the premises was noted 
to be $54.5 \%$. There were no hand sanitizers or alcohol-based hand disinfectants at common touch points except at the hospital. The common problem observed here was that some of these dispensers were empty and refills were not timely. People who reached out to disinfect their hands were unable to. In the hospital one dispenser was empty and another two were press type dispensers without a sensor which required contact with the dispenser and could potentially contaminate the hands. Generally, there were waste containers for the staff at their work areas but none for other general use. Of the workplaces studied, proper distance between workstations were only organized in the banks.

The RA conducted in the private hospital using the OiRA tool revealed that the measures taken are insufficient to protect the staff, patients and others from COVID-19 respiratory disease caused by the SARS-CoV-2 virus. It was identified that the hospital did not make any changes in their usual way of practice other than increasing mask usage. The world is still learning about the new virus and how it spreads, however, it is well known that it mainly spreads from person to person by respiratory droplets that can also be spread by asymptomatic people. The RA conducted revealed 11 highest risk and 9 medium risk situations in the hospital, where the most problematic ones were found to arise from not enforcing the proper physical distance between people and continuing with their usual, prepandemic, way of practice.

This study is the first of its kind, revealing the lack of proper COVID-19 preventive measures in workplaces. Additionally, the importance of having an OSH management system is highlighted, which brings with it regular RAs and emergency preparedness. Globally, the presence of an unexpected, potentially lethal virus raised the need for unusual prevention measures. Simple preventive measures not only reduces the risk of SARS CoV-2 infection but also reduces other infections such as influenza (Galvin et al., 2020; Soo et al., 2020). The health sector, being the most at risk industry for potential exposure must not only take basic preventive measures but go one step further by adopting specific protocols for each medical field of activity. One limitation of the RA part of this study is not being able to include observations of COVID-19 preventive measures during medical procedures. Future studies can focus on specialty specific measures that might need to be taken such as a study conducted in Italy focusing on dental practice (Izzetti et al., 2020). In this study additional measures were recommended at the time of the pandemic such as limiting treatments to those that cannot be postponed, pre-visit data collection to determine patients potentially exposed to SARS CoV-2, and after treatment management. Another limitation is that the data collected at this private hospital may not be representative of all hospitals in NC. Additionally, the hospital in this study was a private hospital that may have more resources compared to public hospitals. The lack of preventive measures may be worse in places with less resources.

Other studies have shown that increasing the public knowledge regarding preventive measures contributes to increased preventive behaviors (Shafiq et al., 2021). Likewise, increasing the knowledge of healthcare workers on the protection level of PPE can increase their use, and their adherence to other preventive measures (Srivastav et al., 2021; Zenbaba et al., 2021). A relationship was found between the belief in science and an increase in mask usage among the general public (Stosic et al., 2021). The general public, as well as workplace employees are more likely to use proper PPE and request preventive measures if scientific evidence for their use is being shared, and there is transparency about the current status of workplace infections or injuries. Another situation which drives the compliance to preventive measures is fear (Kabasakal et al., 2021; Velikonja et al., 2020). Normally health workers knowing the consequences of non-protection comply with preventive measures. Having very low numbers of COVID-19 cases in NC at the time of this study, or not seeing COVID-19 patients in this hospital (as the patients with COVID19 symptoms were directed to the new government pandemic center) may have contributed to not taking additional preventive measures. Nonetheless, the many potential reasons for non-adherence to preventive measures remains a gap in the literature and can be the focus of future investigation. 
Tablo 1. Sectors vs. Mask Usage

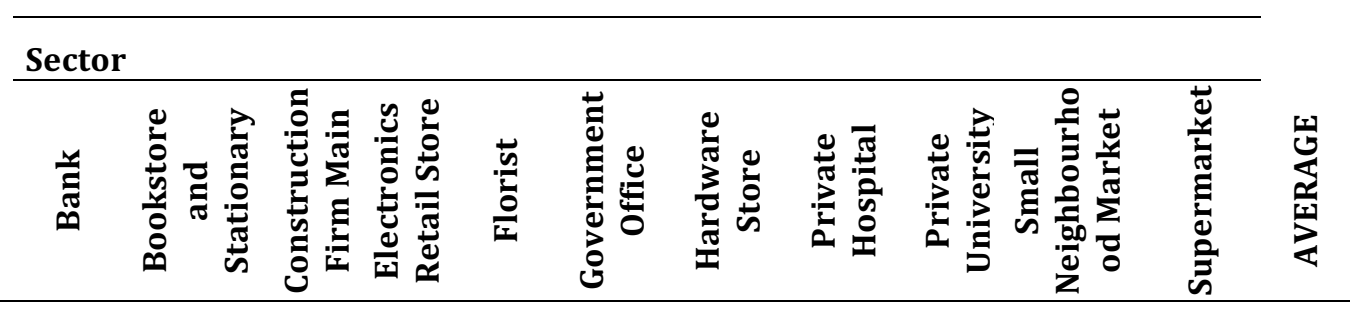

Out of 10

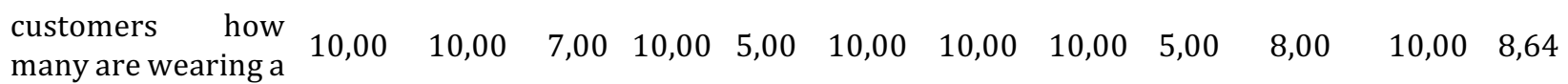
mask?

Out of 10

$\begin{array}{lrlllllllllll}\text { customers how } & 9,00 & 8,00 & 7,00 & 10,00 & 5,00 & 7,00 & 10,00 & 7,00 & 5,00 & 5,00 & 10,00 & 7,55\end{array}$ many are wearing a

mask properly?

Out of 10 $\begin{array}{lllllllllllll}\text { employees how } & 8,00 & 10,00 & 7,00 & 10,00 & 3,30 & 10,00 & 10,00 & 6,00 & 8,00 & 3,30 & 10,00 & 7,78\end{array}$ many are wearing a mask?

Out of 10

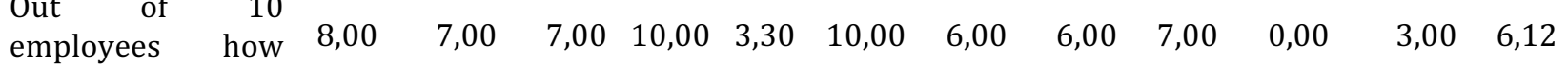
many are wearing a mask properly? 
Table 1. Checklist of Observable Measures

Questions

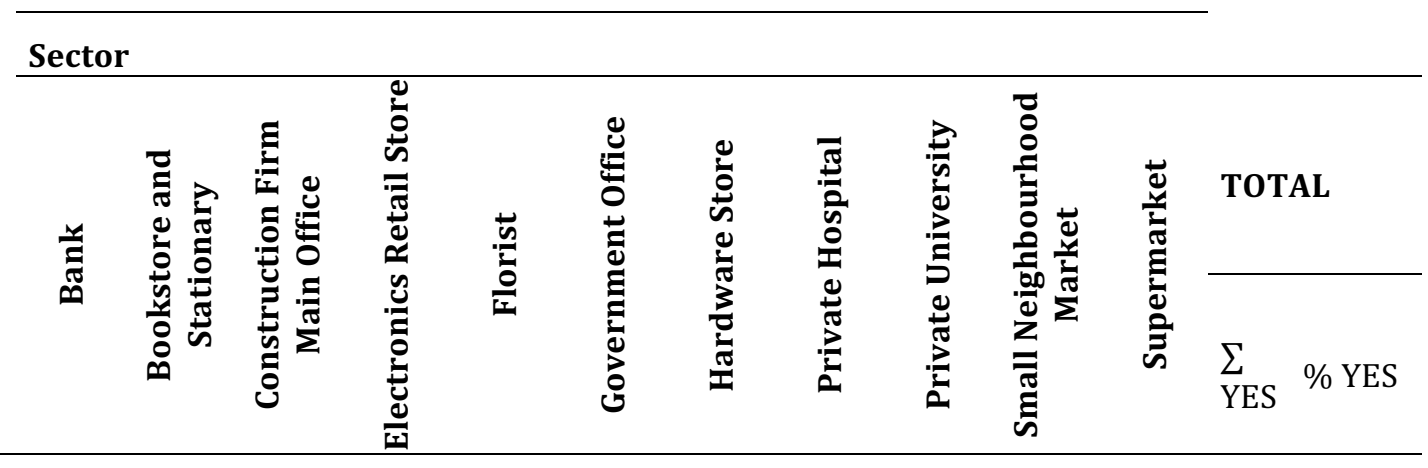

Is there a proper

signage about the rules (COVID-19 measures) at the entrance of the premises?

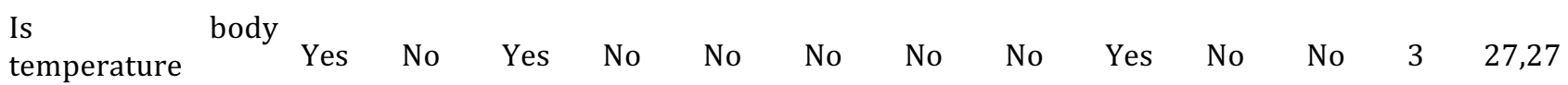
measured at the entrance?

Are they keeping a record of the No No Yes No No No Yes No No No No $2 \quad 18,18$ people entering the workplace?

Are there reminders about COVID-19 No No No No No No No No $\begin{array}{lllllllll}\text { Ne } & \text { No } & \text { No } & 1 & 9,09\end{array}$ measures (proper signage) at key points throughout the premises?

Are the employees wearing masks? Yes Yes Yes Yes Yes Yes Yes Yes Yes No Yes 10 90,91 (answer based on what you see in general)

$\begin{array}{llllllllllllll}\text { Are the employers } & \text { Yes } & \text { Yes } & \text { No } & \text { Yes } & \text { No } & \text { Yes } & \text { Yes } & \text { Yes } & \text { Yes } & \text { No } & \text { Yes } & 8 & 72,73\end{array}$ wearing masks? (In general)

$\begin{array}{llllllllllllll}\begin{array}{l}\text { Are the } \\ \text { customers/visitors }\end{array} & \text { Yes } & \text { Yes } & \text { Yes } & \text { Yes } & \text { Yes } & \text { Yes } & \text { Yes } & \text { Yes } & \text { Yes } & \text { Yes } & \text { Yes } & 11 & 100,00\end{array}$ wearing masks? (In general) 
Are there protective devices installed at reception/cashier areas to prevent infection with COVID-19 due to droplets (plastic shields)?

Is there social distancing signage on the floors to define the distance between the customers?

$\begin{array}{llllllllll}\text { No No No } & \text { Nes No No No No }\end{array}$

Do the premises follow government regulations about the number of customers allowed to enter according to its meter square? Is pedestrian flow

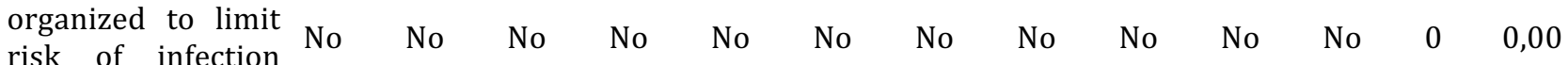
(one-way)?

Are there proper No No No Yes No No No Pes No No No 2 18,18 facilities for hand disinfection?

$\begin{array}{llllllllll}\text { Yes No No No No } & \text { Nes No No No } & \text { No } & \text { No } & 2 & 18,18\end{array}$

Are there alcoholbased hand rub/ disinfection facilities before entering the premises? Yes Yes No Yes No No Yes No $\begin{array}{lllllll} & \text { Yes } & \text { No } & \text { Yes } & 6 & 54,55\end{array}$

Are there alcoholbased hand rub/ disinfection $\mathrm{No}$ facilities at common touch points?

$\begin{array}{lllllllllll}\text { Are there any waste No No No No No No No } & \text { No } & \text { Yes } & \text { No } & \text { No } & 1 & 9,09\end{array}$ container in sufficient places? 


\begin{tabular}{|c|c|c|c|c|c|c|c|c|c|c|c|c|c|}
\hline $\begin{array}{l}\text { Do } \quad \text { waste } \\
\text { containers have a } \\
\text { lid? }\end{array}$ & - & - & - & - & - & - & - & Yes & No & No & No & 1 & 9,09 \\
\hline 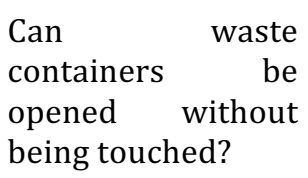 & - & - & - & - & - & - & - & Yes & - & No & No & 1 & 9,09 \\
\hline $\begin{array}{l}\text { Is the workplace } \\
\text { organized to } \\
\text { maintain proper } \\
\text { distance between } \\
\text { employee } \\
\text { workstations/work } \\
\text { areas? }\end{array}$ & Yes & No & No & No & No & No & No & No & No & No & No & 1 & 9,09 \\
\hline$\sum$ YES & 7 & 5 & 4 & 8 & 2 & 4 & 5 & 7 & 8 & 2 & 7 & & \\
\hline$\%$ YES & 38,89 & 27,78 & 22,22 & 44,44 & 11,11 & 22,22 & 27,78 & 38,89 & 44,44 & 11,11 & 38,89 & & \\
\hline
\end{tabular}

Table 3. Results of Private Hospital Risk Assessment Using OiRA Tool

\begin{tabular}{|c|c|c|c|}
\hline Category & Current Situation & $\begin{array}{l}\text { Risk } \\
\text { Level }\end{array}$ & Measure \\
\hline $\begin{array}{l}\text { General } \\
\text { measures: } \\
\text { organization } \\
\text { and } \\
\text { procedures }\end{array}$ & $\begin{array}{l}\text { Staff is not well } \\
\text { informed about all } \\
\text { COVID-19 measures. }\end{array}$ & High & $\begin{array}{l}\text { Proper guidance for staff should be provided. Staff } \\
\text { should be aware of their responsibilities and whenever } \\
\text { necessary should provide information to externals } \\
\text { (patients and others) before they attend the workplace. }\end{array}$ \\
\hline $\begin{array}{l}\text { General } \\
\text { measures: } \\
\text { organization } \\
\text { and } \\
\text { procedures }\end{array}$ & $\begin{array}{l}\text { No specific emergency } \\
\text { communication } \\
\text { procedure is in place. }\end{array}$ & High & $\begin{array}{l}\text { A communication procedure should be established, and } \\
\text { staff should be fully informed about the reasons for the } \\
\text { gathering of personal contact data and that this } \\
\text { information will only be used in emergency situations. } \\
\text { Private data protection rules should be followed. A } \\
\text { room or area at the hospital should be allocated to } \\
\text { safely isolate a person with symptoms, such as a higher } \\
\text { temperature, dry cough, sore throat or headache. } \\
\text { A plan should be in place to safely transfer the person } \\
\text { from the hospital to their home or if necessary another } \\
\text { health care facility. }\end{array}$ \\
\hline
\end{tabular}




$\begin{array}{ll}\text { General } & \text { There are no clear } \\ \text { measures: } & \text { procedures on how to High } \\ \text { organization } & \text { follow up if a staff } \\ \text { and } & \text { member falls sick with } \\ \text { procedures } & \text { COVID-19. }\end{array}$

$\begin{array}{ll} & \begin{array}{l}\text { Specific organizational } \\ \text { measures to reduce } \\ \text { Workplace }\end{array} \\ \text { physical contact are } \\ \text { not adapted } \\ \text { throughout the } \\ \text { hospital. }\end{array}$

High

Physical measures are not considered to

Workplace management

Workplace management

Workplace management

\section{reduce the risk of}

infection in

workspaces and at workstations.

Internal meetings and briefings sometimes do not enable keeping High a safe distance from others.

\section{Cleaning of the} premises is conducted as usual.
In case of a suspected case the national authorities' guidelines should be followed about who to contact. Government procedures and approaches should be adapted to the response plan. Normally, the COVID-19 coordinator in the workplace will be informed about which actions to take and how to identify people who have been in contact with the person having symptoms and will be advised on any actions or precautions that should be taken. Additional PPE for cleaning, such as disposable gloves and an apron, and appropriate PPE to protect the cleaner's eyes, mouth and nose should be available.

Physical distance between employees should be increased. Meetings and briefings as much as possible should be avoided. Alternative communication channels, such as preparing written briefings, using online meeting possibilities should be used and if meeting is necessary it should be limited to as few people as possible. Working procedures/tasks should be organized. Shift changes should be planned so that the employees are not entering and leaving the company at the same time. A suitable schedule should be prepared.

Barriers can be especially made or improvised using items such as plastic sheeting especially when it's not possible to maintain a two meters distance between employees. Where possible, individual work areas should be assigned to each employee. Proper distance to be taken from workstations can be shown with floor markings. The common spaces and jointly used equipment should be cleaned at the end of each shift. Whenever possible, sharing of equipment used by a worker should be minimized, desks or workstations should be moved to achieve physical distancing.

Arrange proper cleaning and ventilation. Try to guarantee a safe distance between participants. The size of the meeting room should be considered, and clear information should be placed on the door about maximum number of people allowed inside to keep appropriate distance.

Detailed cleaning should be planned to be done outside core working hours or at least by avoiding busy periods in the hospital for better compliance with physical distancing measures. Sufficient time should be given for cleaning in between different shifts/meetings etc. A thorough and proper (based on COVID-19 measures) cleaning procedure should be applied. This includes identifying common high-touch surfaces, such as door handles, tables, chairs, handrails, kitchen and bathroom surfaces, taps, toilets, light switches and touch screens. Existing cleaning procedures can be applied at outdoor areas.

Recommendations may change, depending on new research knowledge, therefore consult national or local 
The company holds meetings or events with externals
The company holds meetings or events with externals
There is not a specific preparedness plan for High each meeting.

There is not a specific plan on which actions to take if someone at the meeting starts showing symptoms of COVID-19. authorities for advice for cleaning needs in your sectoral activities. Clean and well-organized workstations ensure better hygiene and better access for cleaning staff. Staff should be informed about the requirements to keep their workstations clean and well organized.

Seats should be arranged to keep the advised distance and a one-way pedestrian flow should be planned (if possible).

Visual hygienic rules such as hand hygiene and coughing and sneezing etiquette should be posted. Ventilation possibilities should be checked and arranged to have air flow. Everyone, all organizers, participants, caterers and visitors at the event should provide contact details such as mobile telephone number, email and address where they are staying, and that this is important to be able to reach them in the case of an emergency. Participants should be informed that the contact details will only be shared with local public health authorities if any participant becomes ill with a suspected infectious disease. Participants in advance should be told that if they have COVID19-like symptoms or feel unwell, they should not attend.

This response plan should include at least the following:

- Know what to do if a meeting participant, staff member or service provider shows COVID-19-like symptoms at the meeting. - Identify a room or area where someone who is feeling unwell or has symptoms can be safely isolated. Consider aspects such as hygiene and ventilation for such an area. Provide a lidded bin lined with a plastic High bag and tissues for the identified area. - Get instructions on which steps to take from the public health authority. National authorities will have procedures in place and will assist you with contacting people who have been in contact with the patient and provide advice on any other actions or precautions that should be taken. Make sure that all participants are informed about your arrangements and procedures in case a person starts showing symptoms of COVID-19 at your meeting. Get instructions on which steps to take from the public health authority. 
The company

holds

meetings or

events with externals
Meetings with external participants does not always consider all preventive measures.
The company

holds

meetings or events with externals
General

measures:

organization

and

procedures
Not all external

meetings have a proper follow-up plan.
High

Provide information or a briefing, preferably both orally and in writing, on COVID-19 and the measures that organizers are taking to make the event safe for participants.

- Encourage regular hand-washing and use of an alcohol rub by all participants at the meeting or event. - Encourage participants to cover their face with the crook of their elbow or a tissue if they cough or sneeze. Supply tissues and closed bins for tissue disposal. - Inform and insist on maintaining the rules for safe distance at the meeting. Lead by example. - Provide contact details or a health hotline number that participants can call for advice and information. If anyone starts to feel unwell, follow your preparedness plan. Open windows and doors whenever possible to make sure that the venue is well ventilated. Place various bottles of hand sanitizer around the venue, especially in high traffic areas and areas close to common high-touch points.

This will help public health authorities with contact tracing of those who may have been exposed to COVID19 if one or more participants become ill shortly after the event. If someone at the meeting or event was isolated as a suspected COVID-19 case, the organizer should let all participants know about the positive case, while respecting privacy as much as possible. Participants should be advised to monitor themselves for symptoms for 14 days. If they start to feel unwell, they should stay at home and contact the relevant public health authority. Inform participants to contact you should they develop COVID-19-like symptoms in the week following the meeting.

Doubts and concerns can cause a lot of trouble. Clear communication to all staff, not only about measures but also about the company situation, prevent staff from speculating. Make sure that important communication on the situation is always consistent, easily understood and reaches all staff at the same time.

- When things do not occur as planned, inform employees why. - Be prepared to justify and reveal information when having to provide information that might be difficult to understand or accept for workers. - Understand the urgency or importance of a message when selecting a communication method. An urgent message is perhaps not suitable to only be displayed on a noticeboard or the intranet. - Use the right medium; important matters might be better done face-to-face as opposed to via email. However, consider the respective guidelines on physical distancing here as well. This could range from managers asking workers more often how they are, facilitating exchanges or buddying between colleagues and changes in work organization and work tasks, to an 
employee assistance program or coaching service, as well as offering contact with an OSH service.

General organization and procedures

There is no specific strategy on how to deal with a high rate of absence.

The pedestrian flow

Workplace has not been management reconsidered to reduce the risk of infection. measures:

Medium

Check the training needs and organize the respective trainings. Consider cross-training workers to perform essential functions so the workplace can operate even if key workers are absent.

Non-essential elements should be removed from the workplace to allow essential elements to be re arranged to have as much distance between them as possible. Clear rules about movement such as sign posting, and proper information provision should be provided. Barriers should be placed if in areas where physical distancing is difficult, floor markings should be introduced, and a one-way system should be used where a two-way system prevents physical distancing. Clear directions of movement should be defined and well communicated with signs and floor markings.

A procedure should be followed allowing just one person entering the reception area at a time. Physical barriers such as clear plastic sneeze guards should be installed. To reduce physical contact written and visual information will be useful especially for informing patients and other non-staff people on procedures and measures in place regarding COVID-19 at your workplace.

Visual signs and other necessary information should be placed outside at entry points. Floor markings should be placed both outside and inside the premises and people should be reminded to follow the rules.

Use of operable windows should be recommended to staff for increasing air exchange. This should be done

Workplace management

No special considerations have been given to the ventilation system regarding COVID-19.

The hygienic use of masks has not been considered for the non-hospitalized and enabling hygienic behaviour patients and others (non-staff). This is only available at staff areas.

Commuting to work and

In some cases, staff local errands or travel travel together in one car for work reasons.
Medium much more than normally, even when this causes some thermal discomfort. If possible, the air ventilation system should be adjusted to not circulate the air inside the hospital.

There should be sufficient closed bins available Medium throughout the hospital for non-staff to be able to dispose of used face masks as soon as possible after use.

Individual travel should be recommended. If not possible, the employer should ask them to limit the number of people traveling together to two. The passenger should sit at the opposite side of the car in Medium the back seat to ensure a maximum distance between them and the driver. Place visual reminders in the car. These include not only hand hygiene and a coughing and sneezing etiquette but also information about keeping physical distance in the car. 
The arrangements of

Externals on deliveries received by site the hospital have not changed because of the COVID-19 outbreak.

No specific measures have been considered to reduce the risk of infection caused by

Medium patients.
Clear instructions should be communicated to the delivery service before the delivery arrives. A clear procedure should be set up for receiving deliveries including: not allowing hand-to-hand acceptance. Post and packages should be left on, for example, a counter or table and if possible, should not be handled immediately. Hands should be washed after handling packages and touching surfaces where packages have been placed. Hygiene facilities should be given to the delivery person if needed.

Waiting rooms should be organized so that patients waiting outside have a sufficiently large distance from each other. Rules should be communicated to them and made sure they are followed. Make individual appointments with patients and leave sufficient time in between appointments to clean any contact points. Plastic shields and other measures to protect your staff and/or patients from each other should be considered and installed where possible.

\section{Conflict of Interest}

No conflict of interest was declared by the authors. 


\section{References}

Abed Alah, M., Abdeen, S., \& Kehyayan, V. (2020). The first few cases and fatalities of Corona Virus Disease 2019 (COVID-19) in the Eastern Mediterranean Region of the World Health Organization: A rapid review. In Journal of Infection and Public Health. https://doi.org/10.1016/j.jiph.2020.06.009

Atasoylu, Emine; Ișık, I. N. (2017). Occupational safety and health in North Cyprus : Evaluation of risk assessment. 94, 17-25. https://doi.org/10.1016/j.ssci.2016.12.020

Bruinen de Bruin, Y., Lequarre, A. S., McCourt, J., Clevestig, P., Pigazzani, F., Zare Jeddi, M., Colosio, C., \& Goulart, M. (2020). Initial impacts of global risk mitigation measures taken during the combatting of the COVID-19 pandemic. Safety Science. https://doi.org/10.1016/j.ssci.2020.104773

CDC. (2020). CDC updates, expands list of people at risk of severe COVID-19 illness. https://www.cdc.gov/media/releases/2020/ p0625-update-expands-covid-19.html

European Agency for Safety and Health at Work. (2020). What is OiRA? https://oiraproject.eu/en/what-oira

Galvin, C. J., Li, Y. C. (Jack), Malwade, S., \& Syed-Abdul, S. (2020). COVID-19 preventive measures showing an unintended decline in infectious diseases in Taiwan. International Journal of Infectious Diseases, 98, 18-20. https://doi.org/10.1016/J.IJID.2020.06.062

Gökçe, A., Üniversitesi, G., \& Kaynakları Yönetimi Bölümü, İ. (2020). İş Sağlığı ve Güvenliği Açısından İş Güvenliği Kültürünün Önemi Üzerine Bir Odak Grup Çalıșması. Ergonomics, 3(2), 82-95. https://doi.org/10.33439/ergonomi.749138

Izzetti, R., Nisi, M., Gabriele, M., \& Graziani, F. (2020). COVID-19 Transmission in Dental Practice: Brief Review of Preventive Measures in Italy. In Journal of Dental Research (Vol. 99, Issue 9). https://doi.org/10.1177/0022034520920580

Kabasakal, E., Özpulat, F., Ayşegül Akca, · \& Özcebe, • L Hilal. (2021). COVID-19 fear and compliance in preventive measures precautions in workers during the COVID-19 pandemic. International Archives of Occupational and Environmental Health, 94, 1239-1247. https://doi.org/10.1007/s00420-021-01682-
2

North Cyprus, L. O. (2020a). ISSYERLERINDE KORONAVIRÜSE (COVID-19) KARŞI ALINMASI GEREKEN GENEL ÖNLEMLER. http://calisma.gov.ct.tr/Portals/39/Isyerlerin de genel covid onlemleri 30_04_2020 $\% 281 \% 29 . p d f$

North Cyprus, L. O. (2020b). KKTC Çalışma Dairesi. http://calisma.gov.ct.tr/

Petersen, E., \& Gökengin, D. (2020). Sars-cov-2 epidemiology and control, different scenarios for Turkey. In Turkish Journal of Medical Sciences. https://doi.org/10.3906/sag-2003260

Shafiq, M., Elharake, J. A., Malik, A. A., McFadden, S. A. M., Aguolu, O. G., \& Omer, S. B. (2021). COVID19 Sources of Information, Knowledge, and Preventive Behaviors among the US Adult Population. Journal of Public Health Management and Practice, 27(3). https://doi.org/10.1097/PHH.000000000000 1348

Soo, R. J. J., Chiew, C. J., Ma, S., Pung, R., \& Lee, V. (2020). Decreased Influenza Incidence under COVID-19 Control Measures, Singapore. Emerging Infectious Diseases, 26(8), 1933. https://doi.org/10.3201/EID2608.201229

Srivastav, A. K., Saini, V., Kukkar, V., Rathore, M. S., Khadayat, S., \& Samuel, A. J. (2021). Safeguarding from COVID-19: educating healthcare workers about the available protective equipment. In Journal of Public Health (Germany). https://doi.org/10.1007/s10389-021-015300

Stosic, M. D., Helwig, S., \& Ruben, M. A. (2021). Greater belief in science predicts maskwearing behavior during COVID-19. Personality and Individual Differences, 176. https://doi.org/10.1016/j.paid.2021.110769

Velikonja, N. K., Erjavec, K., Verdenik, I., Hussein, M., \& Velikonja, V. G. (2020). Association between preventive behaviour and anxiety at the start of the COVID-19 pandemic in Slovenia. Zdravstveno Varstvo, 60(1), 17-24. https://doi.org/10.2478/sjph-2021-0004

WHO. (2020a). Naming the coronavirus disease (COVID-19) and the virus that causes it. https://www.who.int/emergencies/diseases/ 
novel-coronavirus-2019/technicalguidance/naming-the-coronavirus-disease(covid-2019)-and-the-virus-that-causes-it

WHO. (2020b). WHO Director-General's opening remarks at the media briefing on COVID-19 - 11 March 2020. https://www.who.int/directorgeneral/speeches/detail/who-directorgeneral-s-opening-remarks-at-the-mediabriefing-on-covid-19---11-march-2020

Zenbaba, D., Sahiledengle, B., Takele, A., Tekalegn, Y., Yassin, A., Tura, B., Abdulkadir, A., Tesa, E., Tasew, A., Ganfure, G., Fikadu, G., Seyoum, K.,
Abduku, M., Assefa, T., Morka, G., Kemal, M., Gemechu, A., Bekele, K., Tessema, A., ... Esmael, A. (2021). Compliance towards infection prevention measures among health professionals in public hospitals, southeast Ethiopia: a cross-sectional study with implications of COVID-19 prevention. Tropical Medicine and Health, 49(1). https://doi.org/10.1186/s41182-021-00318$\mathrm{y}$ 


\section{Appendix}

Checklist of preventive measures after three months of re-opening following the COVID-19 lockdown in North Cyprus

(Preventive measure observations in different industries)

Sector:

Answer the following questions by counting the first 10 people you see in each category:

Out of 10 customers how many are wearing a mask?

Out of 10 customers how many are wearing a mask properly?

Out of 10 employees how many are wearing a mask?

Out of 10 employees how many are wearing a mask properly?

\begin{tabular}{|c|c|c|}
\hline Checklist of measures to reduce COVID-19 Risk Factors & Yes & No \\
\hline $\begin{array}{l}\text { 1. Is there a proper signage about the rules (COVID-19 measures) at the } \\
\text { entrance of the premises? }\end{array}$ & & \\
\hline 2. Is body temperature measured at the entrance? & & \\
\hline 3. Are they keeping a record of the people entering the workplace? & & \\
\hline $\begin{array}{l}\text { 4. Are there reminders about COVID-19 measures (proper signage) at } \\
\text { key points throughout the premises? }\end{array}$ & & \\
\hline $\begin{array}{l}\text { 5. Are the employees wearing masks? (answer based on what you see } \\
\text { in general) }\end{array}$ & & \\
\hline 6. Are the employers wearing masks? (In general) & & \\
\hline 7. Are the customers/visitors wearing masks? (In general) & & \\
\hline $\begin{array}{l}\text { 8. Are there protective devices installed at reception/cashier areas to } \\
\text { prevent infection with COVID-19 due to droplets (plastic shields)? }\end{array}$ & & \\
\hline $\begin{array}{l}\text { 9. Is there social distancing signage on the floors to define the distance } \\
\text { between the customers? }\end{array}$ & & \\
\hline $\begin{array}{l}\text { 10. Do the premises follow government regulations about the number of } \\
\text { customers allowed to enter according to its meter square? }\end{array}$ & & \\
\hline 11. Is pedestrian flow organized to limit risk of infection (one-way)? & & \\
\hline 12. Are there proper facilities for hand disinfection? & & \\
\hline $\begin{array}{l}\text { 13. Are there alcohol-based hand rub/ disinfection facilities before } \\
\text { entering the premises? }\end{array}$ & & \\
\hline $\begin{array}{l}\text { 14. Are there alcohol-based hand rub/ disinfection facilities at common } \\
\text { touch points? }\end{array}$ & & \\
\hline 15. Are there any waste container in sufficient places? & & \\
\hline 16. Do waste containers have a lid? & & \\
\hline 17. Can waste containers be opened without being touched? & & \\
\hline $\begin{array}{l}\text { 18. Is the workplace organized to maintain proper distance between } \\
\text { employee workstations/work areas? }\end{array}$ & & \\
\hline
\end{tabular}




\title{
INSŞAAT IŞ KAZALARININ ŞIDDETINII ETKILEYEN FAKTÖRLERIN MEVSIMSEL FARKLILIKLARA GÖRE DEĞERLENDİRILMESI
}

\author{
Tufan ÖZTÜRK ${ }^{*}$ Hasan Alpay HEPERKAN² \\ 1 İstanbul Esenyurt Üniversitesi, İşletme ve Yönetim Bilimleri Fakültesi, Havacılık Yönetimi Bölümü \\ ORCID No: http://orcid.org/0000-0003-2685-4824 \\ 2 İstanbul Aydın Üniversitesi, Mühendislik Fakültesi, Makine Mühendisliği Bölümü \\ ORCID No: http://orcid.org/0000-0001-6838-6067
}

\begin{abstract}
Anahtar Kelimeler Öz
İș sağlığı ve iş güvenliği $\quad$ Işs kazası şiddetini etkileyen faktörlerin belirlenmesi hakkında literatürde birçok çalıșmaya

Íş kazaları

Kaza şiddeti

Ergonomi rastlanmıştır. Ancak çok az sayıdaki çalışmada iklimsel faktörlerin, iş kaza şiddeti üzerine etkisinin araştırıldığı görülmüştür. Bu çalışmada genel faktörlere ek olarak iklimsel faktörlerden ısl, nem, rüzgâr, yağış ve hava basıncının inşaat iş kazası şiddeti üzerine etkileri araştırılmıştır. Inşaat iş kazası sonrası kazazedelerin iyileşmesi için gereken tedavi süresi dikkate alınarak, iş kaza şiddeti değişkeni hafif, orta ve ağır olmak üzere üç gruba ayrılmıştır. Bu üç grup tüm faktörlerin ortalamaları bakımından karşılaștırılarak istatistiksel analizler yapılmıştır. Bu analizlerde ANOVA ve Kruskal-Wallis $H$ Testi kullanılmıştır. Analiz sonuçlarına göre inşaat faaliyetlerindeki; kış aylarında kazazedenin genel iş deneyimi arttıkça kaza şiddetinin azaldığı, kış aylarında günlük hava basıncı arttıkça kaza şiddetinin arttığı, yaz aylarında rüzgâr hızı arttıkça kaza şiddetinin azaldığı, kış aylarında rüzgâr hızı arttıkça kaza şiddetinin de arttığı sonuçlarına ulaşılmıştır. Dolayıslyla inşaat faaliyetlerindeki risk değerlendirmelerinde, bu faktörlerin göz önünde bulundurulmasının iş kaza şiddetinin azaltılmasına etki edeceği değerlendirilmektedir. İş sağlı̆̆ı ve güvenliği profesyonellerine, akademisyenlere ve bazı kamu kuruluşlarına tavsiyelerde bulunulmuştur.
\end{abstract}

\section{ASSESSMENT OF THE FACTORS AFFECTING THE SEVERITY OF OCCUPATIONAL ACCIDENTS IN CONSTRUCTION ACCORDING TO SEASONAL DIFFERENCES}

\begin{tabular}{l}
\hline Keywords \\
\hline Occupational health and \\
safety \\
Occupational accidents \\
Accident Severity \\
Ergonomics
\end{tabular}

Ergonomics

\begin{abstract}
There are many studies in the literature on determining the factors affecting the severity of occupational accidents. However, it is observed that very few studies examine the effect of climatic factors on the severity of occupational accidents. In addition to general factors, this study examines the effects of climatic factors such as heat, humidity, wind, precipitation and air pressure on the severity of occupational accidents in construction sites. Taking into consideration the treatment period required for recovery of the victims after occupational construction accidents, the variable of the severity of the occupational accident is divided into three groups as mild, moderate and severe. Statistical analyses have been performed by comparing these three groups in terms of mean values of all factors. ANOVA and Kruskal-Wallis H Test have been used in these analyses. According to the analysis results, it has been concluded for the construction industry that in the winter months the accident severity decreases as the overall work experience of the accident victim increases; the accident severity increases as the daily air pressure increases; and the accident severity increases as the wind speed increases. In addition, it has been determined that the accident severity decreases as the wind speed increases in the summer months. Consequently, it is predicted that taking these factors into consideration in the assessment of risks in construction operations will affect the reduction of the severity of occupational accidents. Several recommendations have been made to occupational health and safety professionals, academics and some public institutions intended.
\end{abstract}

\begin{tabular}{llll}
\hline Araştırma Makalesi & \multicolumn{3}{l}{ Research Article } \\
Başvuru Tarihi & $: 08.05 .2021$ & Submission Date & $: 08.05 .2021$ \\
Kabul Tarihi & $: 13.08 .2021$ & Accepted Date & $: 13.08 .2021$ \\
\hline
\end{tabular}

\footnotetext{
${ }^{*}$ Sorumlu yazar e-posta: tufanozturk@esenyurt.edu.tr Bu çalışma, İstanbul Aydın Üniversitesi Fen Bilimleri Enstitüsü İş Sağlı̆̆ı ve Güvenliği Anabilim Dalında hazırlanan, sorumlu yazarın doktora tezinden üretilmiştir.
} 


\section{Giriş}

Endüstrideki faaliyetler genellikle proses ve/veya proje bazlı olarak sürdürülmektedir. Proses bazlı üretimlerin yapıldığı sektörlerde insan, işin yapılma yöntemi, makina, malzeme, çevre gibi iş kazalarını etkilediği kabul edilen faktörler az sayıda ve nadiren değișime uğramaktadır. Bu nedenle, işletmedeki aynı işlerin, aynı yerde, aynı zamanda, aynı yöntemle, aynı kişiler, tarafından yapılması mümkün hale gelmektedir. Böylece iş planlarının, risk değerlendirmelerinin, alınan önlemlerin güncel kalması ve sürdürülebilirliği sağlanabilmektedir. Proje bazlı üretimlerin yapıldığı inşaat gibi sektörlerde ise insan, işin yapılma yöntemi, makina, malzeme, çevre gibi faktörler üretimin her bir aşamasında sıklıkla farklılaşmaktadır (Lingard ve Rowlinson, 2005). Bu nedenle proje bazlı sektörlerde oluşturulan iş planlarının, risk değerlendirmelerinin, alınan önlemlerin güncel bir şekilde sürdürülebilirliğinin sağlanması zorlaşmaktadır. İnşaat sektöründeki faaliyetler de diğer sektörlerin birçoğundan farklı olarak proje bazlı olarak yürütülmektedir (Gürcanlı, 2013; Baradan vd., 2016).

Tüm dünyada olduğu gibi Türkiye'de de ölümlü iş kazaları en fazla inşaat sektöründe meydana gelmektedir (Yardım vd., 2007; Gambatese vd., 2007; SGK 2019). Türkiye'deki iş kazalarına ait son yılların istatistik verileri incelendiğinde; iş kazası sonrası yaşamını kaybedenlerin yaklaşık \%35'inin inşaat çalışanı olduğu görülmektedir (SGK, 2018; SGK, 2019).

İş kazalarının devlet, işveren, çalışan ile yakınları üzerinde maddi ve manevi birçok olumsuz etkisi bulunmaktadır. Devlet, vatandaşının canını koruyamamış olmakta prestij kaybı yaşamakta ve milli gücünü de bir ölçüde kaybetmektedir. Gelişmekte olan bazı ülkelerde meydana gelen iş kazaları nedeniyle ortaya çıkan doğrudan ve dolaylı maliyetlerin (Gayri Safi Yurt içi Hasıla) GSYİH'nın \%10'una denk geldiği belirtilmektedir. Benzer şekilde işverenin de maddi ve manevi kayıpları oluşmaktadır (Stewart, 2009; Koç ve Akbıyık, 2011; Öztürk ve Caner, 2021). İş kazalarının sonucundan en fazla etkilenen taraf elbette kaza geçiren çalışan yani kazazedenin kendisidir. İş kazası sonrasında kazazede; eski sağlığına kavuşuncaya kadar önceki kapasitesinde çalışamayarak, bazen de çalışma yeteneğini kısmen veya tamamen kaybederek maddi zararlar görmektedir. Ayrıca kazazede iş kazasında acı yaşamakta, engelli kalmakta veya yaşamını kaybetmektedir. Kazazedenin yakınları da maddi ve manevi olarak, bu süreçten olumsuz şekilde etkilenmektedir (Koç ve Akbıyık, 2011; Öztürk, 2019) Ölümlü iş kazaları sonrasında toplumun sosyal yapısı da bir ölçüde değişmektedir. Örneğin: Eşler ölmekte, aile bütünlükleri dağılmakta, çocuklar anne ve babasız kalmaktadır. İnsanların rahat konutlarda yaşayabilmeleri için zor koşullarda çalışan, inşaat işçilerimizin ve ailelerinin korunması öncelikle insani ve vicdani bir vazife olmalıdır. Bu nedenle öncelikle inșaat sektöründe meydana gelen iş kazalarının önlenmesi ve ortaya çıkan iş kazalarının şiddetlerinin azaltılması oldukça önemlidir (Öztürk, vd., 2021; Öztürk ve Caner, 2021).

İş kazalarının önlenmesine yönelik sayısız çalışmalar yapılmıştır. Bunların bir kısmını da istatistiksel çalışmalar oluşturmaktadır. $\mathrm{Bu}$ çalışmaların bir kısmında bir ülke veya sektörde meydana gelen iş kazaları betimlenmiştir (Müngen, 1993; Aksöyek, 2002; Huang, 2003; Çolak vd., 2004; Im vd., 2009; Bilir, 2015; Karadağ, 2017). Bir kısım çalışmada, çalışan grupların iş kazaları bakımından farkları incelenmiștir (Karagüven, 1997; Ahmad vd., 2016; Choi vd., 2019). Bir kısım çalıșmada ise iș kazalarını etkileyen faktörler ve bu faktörlerin iş kazaları ile olan ilişkileri araştırılmıştır (Parsons vd., 1986; Sawacha vd., 1999; Gambatese ve Hinze, 1999; Abdelhamid ve Everett, 2000; Gillen vd., 2002; Aksorn ve Hadikusumo, 2008; Sa vd., 2009; Im vd., 2009; Engin vd., 2009; Koyun, 2013; Alizadeh vd., 2015; Alomari ve Gambatese, 2015; Fass vd., 2017; Ali vd., 2019; Caner vd., 2020). Diğer bir kısım çalıșmada ise iș kazalarını etkileyen faktörlerin belirlenmesi sonrası iş kazası tahmin modelleri oluşturulmaya çalışılmıştır (Fang vd., 2006; Çakan, 2012; Kazan, 2013; Akboğa, 2014; Nordlöf vd., 2017; Akboğa ve Baradan, 2019; Öztürk, 2019; Öztürk vd., 2021).

Öncekilerden farklı olarak az da olsa bazı çalışmalarda iklim faktörlerinin, iș kazası ve kaza şiddeti üzerindeki etkileri araştırılmıştır (Dumrak vd., 2013). İklim faktörlerinden biri olan Isının, çalışan sağlık ve güvenliği üzerindeki etkisinin araştırıldığı bir çalışmada, düşük ısı seviyesinin koruyucu etki gösterdiği yüksek ısı seviyesinin meslek hastalıkları ve yaralanmaları artırdığı sonucuna varılmıștır (Varghese vd., 2019). İnşaat faaliyetlerindeki iş kazalarının araştırıldığı bir çalışmada, yüksek çevre sıcaklığı ile iş kazası sonrası yaralanma durumu arasında pozitif bir ilişki belirlenmiștir (Ricco vd., 2018). Benzer bașka bir çalışmada, literatürdeki eksikliğine de dikkat çekilerek ortam ısısı ile inşaat kazaları arasındaki ilişki incelenmiştir. Söz konusu bu çalışmada açık havada yapılan faaliyetler nedeniyle isı durumunun kaza şiddetini etkilediği belirtilmiștir (Rameezdeen ve Elmualim, 2017). Kısıtlı sayıdaki bu çalışmalarda, iklimsel faktör olarak sadece çevre sıcaklığının kullanıldığı ve analizlerde mevsimsel ayrımların yapılmadığı görülmüştür.

İnşaat faaliyetlerindeki işçi devinim hızı mevsimden mevsime değişiklik göstermektedir. İlkbahar, yaz ve sonbaharın ilk döneminde mevsimsel şartların dış ortamda çalışmaya uygun hale gelmesi ile inşaat 
sektöründeki istihdam oranı artmaktadır. Özellikle eğitim ve öğretim kurumlarının tatil olduğu dönemler ile yaz mevsiminde bu sektördeki öğrenci ve genç çalışan sayısı artmaktadır. Buna karşılık kış dönemindeki istihdam ise genellikle daha tecrübeli ve sürekli çalışan kadrodan oluşmaktadır. $\mathrm{Bu}$ nedenle inşaat faaliyetlerindeki istihdamın niteliğinin de mevsimlere göre farklılık gösterdiği söylenebilir. Ayrıca iklimsel faktörlerin de çalışan üzerindeki etkileri mevsimden mevsime değişebilmektedir. $\mathrm{Bu}$ nedenle kazazede ile işyeri özelliklerinin ve iklimsel faktörlerin inşaat iş kazası ve kaza şiddeti üzerine etkilerinin araștırıldığ çalıșmalarda, mevsimsel farklılıkların göz önünde bulundurulması büyük önem taşımaktadır (Dumrak vd., 2013; Varghese vd., 2019; Ricco vd., 2018; Rameezdeen ve Elmualim, 2017).

Çalışmada kazazede ve işyeri özelliklerine ek olarak hava sıcaklığı, ortam nemi, toplam yağış miktarı, hava basıncı ile rüzgâr hızı iklimsel faktörleri de kullanılmıştır.

\section{Araştırmanın Hipotezleri}

Çalışmanın hipotezleri aşağıda sıralanmıştır.

$\mathrm{H}_{1}$ : Kazazedenin yaşı ile kaza şiddeti arasında istatistiksel bakımdan anlamlı bir ilișki vardır.

$\mathrm{H}_{2}$ : Kazazedenin iş deneyimi ile kaza şiddeti arasında istatistiksel bakımdan anlamlı bir ilişki vardır.

$\mathrm{H}_{3}$ :Kazazedenin son işyerindeki deneyimi ile kaza şiddeti arasında istatistiksel bakımdan anlamlı bir ilişki vardır.

$\mathrm{H}_{4}$ :İşyerindeki çalışan sayısı ile kaza şiddeti arasında istatistiksel bakımdan anlamlı bir ilişki vardır.

$\mathrm{H}_{5}$ :Günlük ortalama hava sıcaklığı ile kaza şiddeti arasında istatistiksel bakımdan anlamlı bir ilişki vardir.

$\mathrm{H}_{6}$ :Günlük ortalama nem miktarı ile kaza şiddeti arasında istatistiksel bakımdan anlamlı bir ilişki vardir.

$\mathrm{H}_{7}$ :Günlük toplam yağış miktarı ile kaza şiddeti arasında istatistiksel bakımdan anlamlı bir ilişki vardir.

$\mathrm{H}_{8}$ :Günlük ortalama hava basıncı ile kaza şiddeti arasında istatistiksel bakımdan anlamlı bir ilișki vardir.

$\mathrm{H}_{9}$ :Günlük ortalama rüzgâr hızı ile kaza şiddeti arasında istatistiksel bakımdan anlamlı bir ilişki vardır.

\section{3. Çalışmanın Uygulandığı Alan ve Verilerin Elde Edilmesi}

$\mathrm{Bu}$ çalışmada İstanbul Küçükçekmece Sosyal Güvenlik Merkezi sorumluluğundaki inşaat firmalarının Avcılar, Bağcılar, Bakırköy, Başakşehir, Büyükçekmece, Çatalca, Fatih, Kadıköy, Kartal, Sarıyer, Silivri, Şişli ve Tuzla bölgelerindeki faaliyetlerinde ortaya çıkan iş kazaları incelenmiştir.

2015, 2016 ve 2017 yıllarına ait kazazede ve çalışma ortamı verileri, Sosyal Güvenlik Kurumu (SGK) tarafinca oluşturulmuş İş Kazası Bildirim Formlarından elde edilmiştir. İş kazasının meydana geldiği zamana ait veriler (güne ait hava sıcaklığı, ortam nemi, toplam yağıș miktarı, hava basıncı ve rüzgâr hızı bilgileri) İstanbul Meteoroloji Müdürlüğünden elde edilmiştir.

\section{4. Çalışmanın Kısıtları}

İstanbul Aydın Üniversitesi ile SGK yazışmaları neticesinde İstanbul SGK İl Müdürlüğü, Küçükçekmece SGK İlçe Müdürlüğü sorumluluğu bölgesindeki inşaat iş kazalarına ait verilere ulaşım sağlanabilmiştir. Ayrıca incelenen bazı iş kaza formlarının işverenler tarafından tam olarak doldurulmadığı da görülmüştür. Eksik veya hatalı bilgi içerdiği kabul edilen veriler çalışma dışı bırakılmış ve sadece 185 İş Kazası Bildirim Formundaki veri değerlendirmeye alınmıştır.

\section{Materyal ve Yöntem}

Kaza şiddeti değişkeni, kazazedenin kazadan etkilenme durumuna göre üç kategorili yapıya dönüştürülmüştür. Bu kapsamda; iş kazası sonrası yaralanma meydana gelmeyen veya en fazla 2 gün dahil tedavi gerektiren iş kazaları hafif şiddetli olarak, iş kazası sonrası 3 gün ve 9 gün arasında tedavi gerektiren iş kazaları orta şiddetli olarak, iş kazası sonrası 10 gün ve daha fazla tedavi gerektiren iş kazaları ile uzuv ve yaşam kaybı meydana gelen iş kazaları ağır şiddetli olarak tanımlanmıştır. Bu kategorilerin belirlenmesinde; işyeri hekiminin en fazla 2 gün, sağlık kuruluşu tek hekiminin en fazla 10 gün istirahat verme yetkileri göz önünde bulundurulmuştur (SSIY,, 2010). İş kazalarının şiddetini etkileyen değişkenlerin belirlenmesi amacıyla bu üç kategori, her bir mevsim için faktörlerin ortalamaları bakımından karşılaştırılmıștır. Bu karşılaştırmaların yapılmasına ANOVA veya Kruskal-Wallis H Testi uygulanmıştır.

\section{1. ANOVA}

ANOVA üç ve daha fazla grubun ortalamaları bakımından karşılaştırılmasında kullanılan parametrik bir yöntemdir. $\mathrm{Bu}$ yöntemin kullanılabilmesi için araştırmadaki veri setinin parametrik analizler için gerekli olan varsayımları 
sağlaması gerekmektedir (Pallant, 2017).

\section{2. Kruskal-Wallis H Testi}

Kruskal-Wallis H Testi üç ve daha fazla grubun ortalamaları bakımından karşılaştırılmasında kullanılan non-parametrik bir yöntemdir. Veri setinin parametrik analizler için gerekli varsayımları karşılayamadığında ANOVA yerine tercih edilmektedir (Pallant, 2017).

\section{3. Levene Testi}

Levene Testi verilere ait varyansların homojenlik şartının kontrolü için kullanılmaktadır. Levene Testi sonucuna göre $p>0,05$ olduğu durumda veri setinin homojenlik şartını sağladığı kabul edilmektedir (Pallant, 2017).

\section{4. Post Hoc Analizi}

ANOVA gruplar arasında istatistiksel bakımdan anlamlı bir fark olduğunu ortaya koyarken, hangi gruplar arasında istatistiksel bakımdan anlamlı fark olduğunun anlaşılmasında Post Hoc analizlerinin kullanılması gerekmektedir. Post Hoc analizi kapsamında da varyansların homojen olduğu durumlarda Tukey, varyansların homojen olmadığı durumlarda ise Games Howell sıklıkla tercih edilen yöntemlerdir (Pallant, 2017).

\section{5. Analiz Varsayımları}

İstatistikte analizler en temelde parametrik ve nonparametrik olmak üzere iki kısıma ayrılmaktadırlar. Non-Parametrik analizler daha güçsüz sonuçlar verirken parametrik analizler daha güçlü sonuçlar vermektedir. $\mathrm{Bu}$ nedenle öncelikle parametrik analizlere yönelmek analiz sonuçlarının güvenilirliği bakımından önemlidir. Parametrik analizlerin varsayımları non-parametrik analizlere göre oldukça fazladır. Bu nedenle analizlere başlamadan önce verilerin bu varsayımları karşılayıp karşılamadığı kontrol edilmelidir. Veriler bu varsayımları sağlıyor ise parametrik analizlere başvurulmalıdır. Veriler bu varsayımları sağlayamıorsa non-parametrik analizleri uygulamak gerekmektedir.

Parametrik analizlerin en temel varsayımları şu şekilde sıralanabilir: Öncelikle araştırmanın en az 30 denekten oluşması, verilerin sayısal ve ölçüm verisi olması, bu verilerin normal dağılması ve varyansların homojen olması gerekmektedir (Sayıcı ve Öztürk, 2020).

$\mathrm{Bu}$ araştırmada seçilecek doğru yönteme karar vermek için öncelikle tüm ölçüm verilerinin betimsel özellikleri incelenmiștir. Bu incelemeler sonunda veri setindeki kazazede yaşı, kazazedenin genel iş deneyimi, işyeri çalışan sayısı, günlük ortalama sıcaklık, günlük ortalama nem, günlük ortalama hava basıncı, günlük ortalama rüzgâr hızı değişkenlerinin parametrik testler için uygun olduğu değerlendirilmiştir. Diğer taraftan kazazedenin son işyerindeki deneyimi ve günlük toplam yağış değişkenlerinin non-parametrik testler için daha uygun olacağı değerlendirilmiştir. $\mathrm{Bu}$ nedenle çalışmada, parametrik olan ANOVA ve nonparametrik olan Kruskal-Wallis $\mathrm{H}$ Testi kullanılmasına karar verilmiştir.

\section{Bulgular}

\subsection{Betimsel Analizler}

Elde edilen bilgiler, kategorik verilerin oransal dağılımları, sürekli verilerin ise ortalama, standart sapma ve çarpıklık değerleri incelenmiştir. Sürekli verilerin normal dağılım gösterip göstermediği, varyansların homojen olup olmadığı araştırılmıştır. $\mathrm{Bu}$ bilgilerden elde edilenlerle parametrik test varsayımlarının sağlanıp sağlanmadığı da incelenmiştir.

Kazazedelerin, mevsimlere göre sayısal ve oransal olarak dağılımı Tablo 1'de verilmiştir.

Tablo 1. Kazazedelerin Mevsimlere Göre Dağılımı

\begin{tabular}{lcc}
\hline Kaza Mevsimi & $\begin{array}{c}\text { Kazazede } \\
\text { Sayısı }\end{array}$ & Yüzde (\%) \\
\hline İlkbahar & 60 & 32,43 \\
Yaz & 41 & 22,16 \\
Sonbahar & 42 & 22,70 \\
Kış & 42 & 22,70 \\
\hline Toplam & 185 & 100,00 \\
\hline
\end{tabular}

Tablo 1 incelendiğinde ilkbahar mevsimindeki kazazede sayısının diğer üç mevsime göre daha fazla olduğu görülmektedir. Bu bilgiden, ilkbaharın iş kazalarını artırdığı gibi bir algıya kapılmamak gerekmektedir. Çünkü inşaat sektöründeki istihdamın da ilkbaharda arttığı ve mevsimden mevsime farklılık gösterdiği bilinmektedir.

$\mathrm{Bu}$ araştırmanın ölçüm verileri olan kazazede yaşı, kazazedenin genel iş deneyimi, kazazedenin son işyerindeki iş deneyimi, işyerinde çalışan sayısı, günlük ortalama sıcaklık, günlük ortalama nem, günlük toplam yağış, günlük ortalama hava basıncı ve günlük ortalama rüzgâr hızı değerlerinin betimsel istatistiki bilgileri Tablo 2'de verilmiştir. 
Tablo 2. Ölçüm Verilerine Ait Betimsel İstatistiki Bilgiler

\begin{tabular}{|c|c|c|c|c|c|c|c|c|c|}
\hline Özellikler & 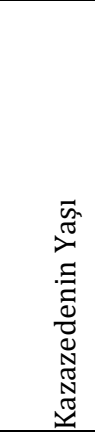 & 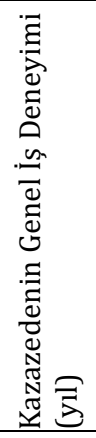 & 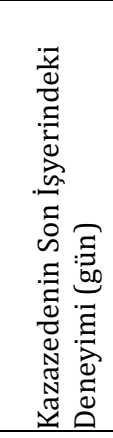 & 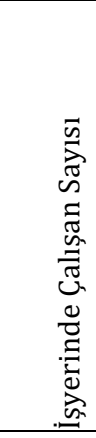 & 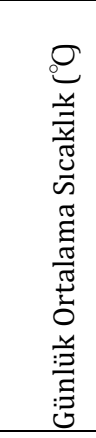 & 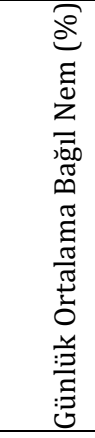 & 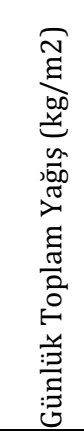 & 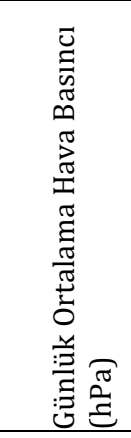 & 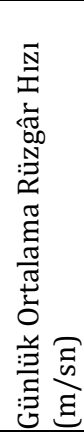 \\
\hline Kazazede Sayısı & 185 & 185 & 185 & 172 & 185 & 185 & 185 & 185 & 185 \\
\hline Aritmetik Ortalama & 33,24 & 13,26 & 84,85 & 86,53 & 14,90 & 75,86 & 2,15 & 1012,00 & 2,63 \\
\hline Standart Sapma & 11,02 & 10,19 & 111,80 & 69,09 & 6,97 & 10,10 & 6,58 & 6,52 & 0,99 \\
\hline Çarpıklık & 0,63 & 0,80 & 2,81 & 1,05 & 0,12 & $-0,07$ & 6,76 & $-0,03$ & 0,56 \\
\hline
\end{tabular}

Tablo 2 incelendiğinde kazazedenin son işyerindeki deneyimi ve işyerinde çalışan sayısı verilerinin çarpıklık katsayısının -1 ve +1 aralığı dışında kaldığı görülmektedir. $\mathrm{Bu}$ nedenle bu iki değișkene ait verilerin normal dağılmadığı kabul edilmiștir. Diğer değişkenlere ait verilerin çarpıklık katsayılarının -1 ve +1 aralığında kaldığı ve bu nedenle de normal dağıldığı kabul edilmiştir (Pallant, 2017). Materyal ve Yöntem Bölümü'nde de belirtildiği gibi, araştırmadaki analizler her mevsim için ayrı ayrı yapılmıștır. Bu nedenle araştırmadaki tüm ölçüm verilerinin betimsel özellikleri her bir mevsim için ayrı ayrı hesaplanarak Tablo 3'te verilmiştir.

Tablo 3. Mevsimlere Ayrılmış Ölçüm Verilerine Ait Betimsel İstatistiki Bilgiler

\begin{tabular}{|c|c|c|c|c|c|c|c|c|c|c|}
\hline $\begin{array}{c}\text { Kaza } \\
\text { Mevsimi }\end{array}$ & Özellikler & 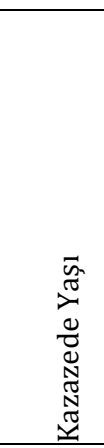 & 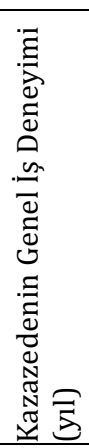 & 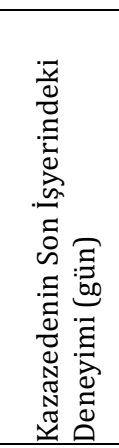 & 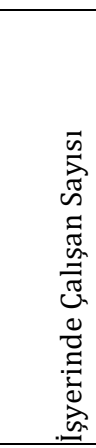 & 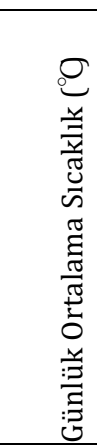 & 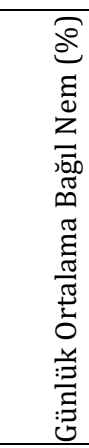 & 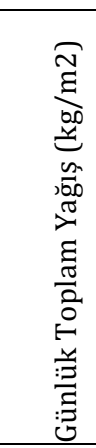 & 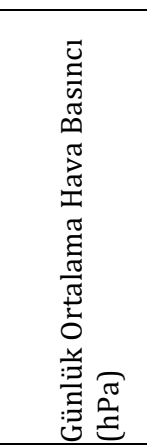 & 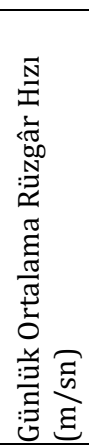 \\
\hline \multirow{4}{*}{ İlkbahar } & Kazazede Sayısı & 60 & 60 & 60 & 56 & 60 & 60 & 60 & 60 & 60 \\
\hline & Aritmetik Ortalama & 34,22 & 14,38 & 79,80 & 84,82 & 12,79 & 72,78 & 0,98 & 1011,67 & 2,33 \\
\hline & Standart Sapma & 11,68 & 11,18 & 92,27 & 59,08 & 4,16 & 10,95 & 2,96 & 6,34 & 1,02 \\
\hline & Çarpıklık & 0,57 & 0,72 & 2,60 & 0,49 & $-0,24$ & $-0,22$ & 4,23 & $-0,50$ & 1,42 \\
\hline \multirow{4}{*}{ Yaz } & Kazazede Sayısı & 41 & 41 & 41 & 41 & 41 & 41 & 41 & 41 & 41 \\
\hline & Aritmetik Ortalama & 33,73 & 12,97 & 86,15 & 90,54 & 24,22 & 72,60 & 0,50 & 1008,77 & 2,73 \\
\hline & Standart Sapma & 10,61 & 8,53 & 106,83 & 75,82 & 2,43 & 8,48 & 2,11 & 3,40 & 0,90 \\
\hline & Çarpıklık & 0,60 & 0,71 & 3,47 & 0,97 & $-0,12$ & 0,02 & 5,38 & $-0,22$ & 0,08 \\
\hline \multirow{4}{*}{ Sonbahar } & Kazazede Sayısı & 42 & 42 & 42 & 39 & 42 & 42 & 42 & 42 & 42 \\
\hline & Aritmetik Ortalama & 31,10 & 12,04 & 67,57 & 75,26 & 16,49 & 78,27 & 3,53 & 1013,62 & 2,83 \\
\hline & Standart Sapma & 10,08 & 9,57 & 99,91 & 79,88 & 4,60 & 9,13 & 11,04 & 5,47 & 0,96 \\
\hline & Çarpıklık & 0,67 & 1,09 & 2,54 & 1,64 & 0,15 & 0,55 & 5,60 & 0,27 & 0,21 \\
\hline \multirow{4}{*}{ Kış } & Kazazede Sayısı & 42 & 42 & 42 & 36 & 42 & 42 & 42 & 42 & 42 \\
\hline & Aritmetik Ortalama & 33,52 & 13,19 & 108,10 & 96,86 & 7,28 & 81,03 & 4,05 & 1015,76 & 2,77 \\
\hline & Standart Sapma & 11,42 & 10,97 & 147,56 & 63,73 & 3,32 & 8,60 & 6,73 & 8,03 & 0,98 \\
\hline & Çarpıklık & 0,68 & 0,67 & 2,41 & 1,04 & 0,13 & 0,21 & 1,67 & $-0,80$ & 0,33 \\
\hline
\end{tabular}


Tablo 3 incelenerek verilerin normal dağılıp dağılmadığı sorgulanmış ve uygun yönteme karar verilmiştir. Bu kapsamda, her mevsimdeki kazazede yaşı, günlük ortalama sıcaklık, günlük ortalama nem, günlük ortalama hava basıncı verileri ile ANOVA uygulanmıştır. Her mevsimdeki kazazedenin son işyerindeki deneyimi, günlük toplam yağış verileri ile Kruskal-Wallis H Testi uygulanmıştır. Sonbahar mevsimindeki kazazedenin genel iş deneyimi verisi ile Kruskal-Wallis H Testi, ilkbahar, yaz ve kış mevsimlerindeki verileri ile ANOVA uygulanmıştır. Sonbahar ve kış mevsimindeki işyerinde çalışan sayısı verisi ile Kruskal-Wallis H Testi, ilkbahar, yaz mevsimlerindeki verileri ile ANOVA uygulanmıştır. İlkbahar mevsimindeki günlük ortalama rüzgâr hızı verisi ile Kruskal-Wallis H Testi, diğer üç mevsimdeki verileri ile ANOVA uygulanmıştır. ANOVA uygulanacak verilerin varyanslarının homojenlik testleri de Levene Testi ile yapılmış ve sonuçları Tablo 4'te verilmiştir.

Tablo 4. Varyansların Homojenlik Testi

\begin{tabular}{|c|c|c|c|c|}
\hline $\begin{array}{c}\text { Kaza } \\
\text { Mevsimi }\end{array}$ & Değişkenler & Levene İstatistik & $\begin{array}{l}\text { Serbestlik } \\
\text { Derecesi }\end{array}$ & $\begin{array}{l}\text { Anlamlılık } \\
\text { (p) }\end{array}$ \\
\hline \multirow{7}{*}{ İlkbahar } & Kazazede Yaşı & 1,05 & 57 & 0,36 \\
\hline & Kazazedenin Genel İş Deneyimi (yıl) & 1,47 & 57 & 0,24 \\
\hline & İşyerinde Çalışan Sayısı & 4,77 & 53 & 0,01 \\
\hline & Günlük Ortalama Sıcaklık $\left({ }^{\circ} \mathrm{O}\right.$ & 2,59 & 57 & 0,08 \\
\hline & Günlük Ortalama Nem (\%) & 2,91 & 57 & 0,06 \\
\hline & Günlük Ortalama Hava Basıncı (hPa) & 1,32 & 57 & 0,28 \\
\hline & Günlük Ortalama Rüzgâr Hızı (m/sn) & 3,09 & 57 & 0,05 \\
\hline \multirow{7}{*}{ Yaz } & Kazazede Yaş & 0,63 & 38 & 0,54 \\
\hline & Kazazedenin Genel İș Deneyimi (yıl) & 0,53 & 38 & 0,59 \\
\hline & İşyerinde Çalışan Sayısı & 1,12 & 38 & 0,34 \\
\hline & Günlük Ortalama Sıcaklık $\left({ }^{\circ} \mathrm{O}\right.$ & 0,65 & 38 & 0,53 \\
\hline & Günlük Ortalama Nem (\%) & 1,52 & 38 & 0,23 \\
\hline & Günlük Ortalama Hava Basıncı (hPa) & 3,58 & 38 & 0,04 \\
\hline & Günlük Ortalama Rüzgâr Hızı & 2,48 & 38 & 0,10 \\
\hline \multirow{7}{*}{ Sonbahar } & Kazazede Yaş & 0,74 & 39 & 0,48 \\
\hline & Kazazedenin Genel İş Deneyimi (yıl) & 0,52 & 39 & 0,60 \\
\hline & İşyerinde Çalışan Sayısı & 4,82 & 36 & 0,01 \\
\hline & Günlük Ortalama Sıcaklık $\left({ }^{\circ} \mathrm{O}\right.$ & 0,53 & 39 & 0,59 \\
\hline & Günlük Ortalama Nem (\%) & 1,09 & 39 & 0,35 \\
\hline & Günlük Ortalama Hava Basıncı (hPa) & 0,61 & 39 & 0,55 \\
\hline & Günlük Ortalama Rüzgâr Hızı (m/sn) & 0,61 & 39 & 0,55 \\
\hline \multirow{7}{*}{ Kış } & Kazazede Yaş & 3,09 & 39 & 0,06 \\
\hline & Kazazedenin Genel İș Deneyimi (yıl) & 4,98 & 39 & 0,01 \\
\hline & İşyerinde Çalışan Sayısı & 0,68 & 33 & 0,51 \\
\hline & Günlük Ortalama Sıcaklık $\left({ }^{\circ} \mathrm{O}\right.$ & 1,12 & 39 & 0,34 \\
\hline & Günlük Ortalama Nem (\%) & 2,42 & 39 & 0,10 \\
\hline & Günlük Ortalama Hava Basıncı (hPa) & 1,85 & 39 & 0,17 \\
\hline & Günlük Ortalama Rüzgâr Hızı (m/sn) & 0,56 & 39 & 0,57 \\
\hline
\end{tabular}

Tablo 4 incelendiğinde anlamlılık (p) değeri 0,05'ten büyük olan değişkenlerin varyanslarındaki değişimin homojen olduğu, anlamlılık (p) değeri 0,05'ten küçük olan değişkenlerin varyanslarındaki değişimin homojen olmadığı anlaşılmaktadır. Varyansları homojen olan değişkenlerin ANOVA kapsamında bulunan Post Hoc analizinde Tukey 
yöntemi kullanılmıştır. Varyansları homojen olmayan değişkenlerin ANOVA kapsamında ise Games Howell yöntemi kullanılmıştır.
Hafif, orta ve ağır şiddetli kaza geçiren kazazede grupları arasında, kazazedelerin yaşları bakımından istatistiksel olarak anlamlı farkın sorgulandığı ANOVA çıktısı Tablo 5'te verilmiştir.

\subsection{ANOVA Uygulaması}

Tablo 5. Kaza Şiddeti Gruplarının Kazazede Yaşı Ortalamaları Bakımından Karşılaştırıldığı ANOVA

\begin{tabular}{|c|c|c|c|c|c|c|}
\hline $\begin{array}{c}\text { Kaza } \\
\text { Mevsimi }\end{array}$ & Gruplar & $\begin{array}{l}\text { Kareler } \\
\text { Toplamı }\end{array}$ & $\begin{array}{c}\text { Serbestlik } \\
\text { Derecesi }\end{array}$ & $\begin{array}{c}\text { Kareler } \\
\text { Ortalaması }\end{array}$ & $\mathrm{F}$ & $\begin{array}{c}\text { Anlamlılık } \\
\text { (p) }\end{array}$ \\
\hline \multirow{3}{*}{ İlkbahar } & Gruplar arası & 465,02 & 2 & 232,51 & 1,75 & 0,18 \\
\hline & Gruplar içi & 7581,16 & 57 & 133,00 & & \\
\hline & Toplam & 8046,18 & 59 & & & \\
\hline \multirow{3}{*}{ Yaz } & Gruplar arası & 378,69 & 2 & 189,34 & 1,74 & 0,19 \\
\hline & Gruplar içi & 4127,36 & 38 & 108,61 & & \\
\hline & Toplam & 4506,05 & 40 & & & \\
\hline \multirow{3}{*}{ Sonbahar } & Gruplar arası & 148,85 & 2 & 74,43 & 0,72 & 0,49 \\
\hline & Gruplar içi & 4020,76 & 39 & 103,09 & & \\
\hline & Toplam & 4169,62 & 41 & & & \\
\hline \multirow{3}{*}{ Kış } & Gruplar arası & 595,49 & 2 & 297,75 & 2,45 & 0,10 \\
\hline & Gruplar içi & 4746,98 & 39 & 121,72 & & \\
\hline & Toplam & 5342,47 & 41 & & & \\
\hline
\end{tabular}

Tablo 5 incelendiğinde dört mevsim için de hafif, orta ve ağır şiddetli kaza geçiren kazazede grupları arasında, kazazedelerin yaşları bakımından istatistiksel olarak anlamlı farkın olmadığı anlaşılmaktadır $\mathrm{p}>0,05$. Diğer bir deyişle kazazede yaşlarındaki farklılığın, geçirilen kazanın şiddetini etkilemediği görülmektedir. Hafif, orta ve ağır şiddetli kaza geçiren kazazede grupları arasında, kazazedelerin genel iş deneyimi bakımından istatistiksel farkın sorgulandığı ANOVA çıktısı Tablo 6'da verilmiștir.

Tablo 6. Kaza Şiddeti Gruplarının Kazazede Genel İş Deneyimi (Yıl) Ortalamaları Bakımından Karşılaştırıldı̆̆ı ANOVA

\begin{tabular}{|c|c|c|c|c|c|c|}
\hline $\begin{array}{c}\text { Kaza } \\
\text { Mevsimi }\end{array}$ & Gruplar & $\begin{array}{l}\text { Kareler } \\
\text { Toplamı }\end{array}$ & $\begin{array}{c}\text { Serbestlik } \\
\text { Derecesi }\end{array}$ & $\begin{array}{c}\text { Kareler } \\
\text { Ortalaması }\end{array}$ & $\mathrm{F}$ & $\begin{array}{c}\text { Anlamlılık } \\
(p)\end{array}$ \\
\hline & Gruplar arası & 329,14 & 2 & 164,60 & 1,33 & 0,27 \\
\hline \multirow[t]{3}{*}{ İlkbahar } & Gruplar içi & 7044,62 & 57 & 123,60 & & \\
\hline & Toplam & 7373,75 & 59 & & & \\
\hline & Gruplar arası & 42,55 & 2 & 21,28 & 0,28 & 0,76 \\
\hline \multirow[t]{3}{*}{ Yaz } & Gruplar içi & 2868,88 & 38 & 75,50 & & \\
\hline & Toplam & 2911,43 & 40 & & & \\
\hline & Gruplar arası & 117,43 & 2 & 58,72 & 0,63 & 0,54 \\
\hline \multirow[t]{3}{*}{ Sonbahar } & Gruplar içi & 3637,15 & 39 & 93,26 & & \\
\hline & Toplam & 3754,58 & 41 & & & \\
\hline & Gruplar arası & 845,55 & 2 & 422,80 & 4,03 & 0,03 \\
\hline \multirow[t]{2}{*}{ Kış } & Gruplar içi & 4 087,71 & 39 & 104,80 & & \\
\hline & Toplam & 4933,27 & 41 & & & \\
\hline
\end{tabular}


Tablo 6 incelendiğinde sadece kış mevsimindeki hafif, orta ve ağır şiddetli kaza geçiren kazazede grupları arasında, Kazazedenin Genel İş Deneyimi bakımından istatistiksel olarak anlamlı bir farkın olduğu anlaşılmaktadır $F(2,39)=4,03, p<0,05$. Diğer bir deyişle kış aylarında kazazedenin genel iş deneyimindeki farklılığın geçirilen kazanın şiddetini etkilediği görülmektedir. Kış mevsiminde oluşan bu farkın hangi gruplar arasında meydana geldiği ve niteliğinin anlaşılabilmesi amacıyla Post Hoc (Games Howell) analizi yapılmıș ve test çıktısı Tablo 7'de verilmiştir.

Tablo 7. Kış Mevsimi İçin Kaza Şiddeti Gruplarının Kazazedelerin Genel İş Deneyimi (Yıl) Ortalamaları Bakımından Karşılaştırıldığı Post Hoc (Games Howell) Testi

\begin{tabular}{|c|c|c|c|c|c|c|}
\hline \multirow{2}{*}{\multicolumn{2}{|c|}{ Kaza Şiddeti }} & \multirow{2}{*}{$\begin{array}{c}\text { Ortalamalar } \\
\text { Farkı }\end{array}$} & \multirow{2}{*}{ Standart Hata } & \multirow{2}{*}{$\begin{array}{l}\text { Anlamlilık } \\
\text { (p) }\end{array}$} & \multicolumn{2}{|c|}{ 95\% Güven Sınır Aralığı } \\
\hline & & & & & Alt & Üst \\
\hline \multirow{2}{*}{ Hafif } & Orta & 9,75 & 3,08 & 0,01 & 2,21 & 17,29 \\
\hline & Ağır & 0,23 & 4,56 & 1,00 & $-12,30$ & 12,77 \\
\hline \multirow{2}{*}{ Orta } & Hafif & $-9,75$ & 3,08 & 0,01 & $-17,30$ & $-2,21$ \\
\hline & Ağır & $-9,52$ & 4,22 & 0,13 & $-21,80$ & 2,77 \\
\hline \multirow{2}{*}{ Ağır } & Hafif & $-0,23$ & 4,56 & 1,00 & $-12,80$ & 12,32 \\
\hline & Orta & 9,52 & 4,22 & 0,13 & $-2,77$ & 21,82 \\
\hline
\end{tabular}

Tablo 7 incelendiğinde kazazedenin genel iş deneyimi arttıkça daha hafif şiddette iş kazası geçirildiği anlaşılmaktadır. Hafif, orta ve ağır şiddetli kaza geçiren kazazede grupları arasında, işyerindeki çalışan sayısı bakımından istatistiksel farkın sorgulandığı ANOVA çıktısı Tablo 8'de verilmiştir.

Tablo 8. Kaza Şiddeti Gruplarının İşyeri Çalışan Sayısı Ortalamaları Bakımından Karşılaştırıldığı ANOVA

\begin{tabular}{|c|c|c|c|c|c|c|}
\hline $\begin{array}{c}\text { Kaza } \\
\text { Mevsimi }\end{array}$ & Gruplar & $\begin{array}{l}\text { Kareler } \\
\text { Toplamı }\end{array}$ & $\begin{array}{l}\text { Serbestlik } \\
\text { Derecesi }\end{array}$ & $\begin{array}{c}\text { Kareler } \\
\text { Ortalaması }\end{array}$ & $\mathrm{F}$ & $\begin{array}{c}\text { Anlamlılık } \\
\text { (p) }\end{array}$ \\
\hline \multirow{3}{*}{ İlkbahar } & Gruplar arası & 3430,53 & 2 & 1715,26 & 0,48 & 0,62 \\
\hline & Gruplar içi & 188563,69 & 53 & 3557,81 & & \\
\hline & Toplam & 191994,21 & 55 & & & \\
\hline \multirow{3}{*}{ Yaz } & Gruplar arası & 5263,94 & 2 & 2631,97 & 0,45 & 0,64 \\
\hline & Gruplar içi & 224704,25 & 38 & 5913,27 & & \\
\hline & Toplam & 229968,20 & 40 & & & \\
\hline \multirow{3}{*}{ Sonbahar } & Gruplar arası & 21166,16 & 2 & 10583,08 & 1,72 & 0,19 \\
\hline & Gruplar içi & 221313,28 & 36 & 6147,59 & & \\
\hline & Toplam & 242479,44 & 38 & & & \\
\hline \multirow{3}{*}{ Kış } & Gruplar arası & 3478,46 & 2 & 1739,23 & 0,41 & 0,66 \\
\hline & Gruplar içi & 138687,85 & 33 & 4202,66 & & \\
\hline & Toplam & 142166,31 & 35 & & & \\
\hline
\end{tabular}

Tablo 8 incelendiğinde dört mevsim için de hafif, orta ve ağır şiddetli kaza geçiren kazazede grupları arasında, işyerindeki çalışan sayısı bakımından istatistiksel olarak anlamlı farkın olmadığ anlaşılmaktadır $(p>0,05)$. Diğer bir deyişle işyeri çalışan sayısındaki farklılık geçirilen kazanın şiddetini etkilememektedir. Hafif, orta ve ağır şiddetli kaza geçiren kazazede grupları arasında, kazanın yaşandığı günlerdeki ortalama hava sıcaklığı bakımından istatistiksel olarak anlamlı farkın sorgulandığı ANOVA çıktısı Tablo 9'da verilmiştir. 
Tablo 9. Kaza Şiddeti Gruplarının Kazanın Yaşandığı Günlerdeki Ortalama Hava Sıcaklığı Ortalamaları Bakımından Karşılaştırıldığı ANOVA

\begin{tabular}{|c|c|c|c|c|c|c|}
\hline $\begin{array}{c}\text { Kaza } \\
\text { Mevsimi }\end{array}$ & Gruplar & $\begin{array}{l}\text { Kareler } \\
\text { Toplamı }\end{array}$ & $\begin{array}{c}\text { Serbestlik } \\
\text { Derecesi }\end{array}$ & $\begin{array}{l}\text { Kareler } \\
\text { Ortalaması }\end{array}$ & $\mathrm{F}$ & $\begin{array}{l}\text { Anlamlılık } \\
\text { (p) }\end{array}$ \\
\hline \multirow{3}{*}{ İlkbahar } & Gruplar arası & 88,65 & 2 & 44,33 & 2,70 & 0,08 \\
\hline & Gruplar içi & 934,59 & 57 & 16,40 & & \\
\hline & Toplam & 1023,24 & 59 & & & \\
\hline \multirow{3}{*}{ Yaz } & Gruplar arası & 8,23 & 2 & 4,12 & 0,68 & 0,51 \\
\hline & Gruplar içi & 228,42 & 38 & 6,01 & & \\
\hline & Toplam & 236,66 & 40 & & & \\
\hline \multirow{3}{*}{ Sonbahar } & Gruplar arası & 75,41 & 2 & 37,71 & 1,86 & 0,17 \\
\hline & Gruplar içi & 790,50 & 39 & 20,27 & & \\
\hline & Toplam & 865,92 & 41 & & & \\
\hline \multirow{3}{*}{ Kış } & Gruplar arası & 53,17 & 2 & 26,59 & 2,60 & 0,09 \\
\hline & Gruplar içi & 399,21 & 39 & 10,24 & & \\
\hline & Toplam & 452,38 & 41 & & & \\
\hline
\end{tabular}

Tablo 9 incelendiğinde dört mevsim için de hafif, orta ve ağır şiddetli kaza geçiren kazazede grupları arasında, kazanın yaşandığı günlerin ortalama hava sıcaklığı bakımından istatistiksel olarak anlamlı farkın olmadığı anlaşılmaktadır ( $p>0,05)$. Diğer bir deyişle günlük ortalama hava sıcaklığındaki farklılık geçirilen kazanın şiddetini etkilememektedir. Buna rağmen ilkbahar ve kış aylarında meydana gelen kazaların șiddetinin \%90 güven düzeyinde ortam sıcaklığından etkilendiği görülmektedir $(\mathrm{p}<0,10)$.

Hafif, orta ve ağır şiddetli kaza geçiren kazazede grupları arasında, kazanın yaşandığı günlerdeki ortalama nem miktarı bakımından istatistiksel olarak anlamlı farkın sorgulandığı ANOVA çıktısı Tablo 10'da verilmiştir.

Tablo 10. Kaza Şiddeti Gruplarının Kazanın Yaşandığı Günlerdeki Ortalama Nem Miktarı Ortalamaları Bakımından Karşılaştırıldı̆̆ı ANOVA

\begin{tabular}{|c|c|c|c|c|c|c|}
\hline $\begin{array}{c}\text { Kaza } \\
\text { Mevsimi }\end{array}$ & Gruplar & Kareler Toplamı & $\begin{array}{c}\text { Serbestlik } \\
\text { Derecesi }\end{array}$ & $\begin{array}{r}\text { Kareler } \\
\text { Ortalaması }\end{array}$ & $\mathrm{F}$ & $\begin{array}{l}\text { Anlamlılık } \\
\text { (p) }\end{array}$ \\
\hline \multirow{3}{*}{ İlkbahar } & Gruplar arası & 186,07 & 2 & 93,03 & 0,77 & 0,47 \\
\hline & Gruplar içi & 6884,12 & 57 & 120,77 & & \\
\hline & Toplam & 7070,19 & 59 & & & \\
\hline \multirow{3}{*}{ Yaz } & Gruplar arası & 13,57 & 2 & 6,78 & 0,09 & 0,91 \\
\hline & Gruplar içi & 2864,54 & 38 & 75,38 & & \\
\hline & Toplam & 2878,11 & 40 & & & \\
\hline \multirow{3}{*}{ Sonbahar } & Gruplar arası & 248,60 & 2 & 124,30 & 1,53 & 0,23 \\
\hline & Gruplar içi & 3170,46 & 39 & 81,29 & & \\
\hline & Toplam & 3419,07 & 41 & & & \\
\hline \multirow{3}{*}{ Kış } & Gruplar arası & 329,56 & 2 & 164,78 & 2,38 & 0,11 \\
\hline & Gruplar içi & 2700,96 & 39 & 69,26 & & \\
\hline & Toplam & 3030,53 & 41 & & & \\
\hline
\end{tabular}


Tablo 10 incelendiğinde dört mevsim için de hafif, orta ve ağır şiddetli kaza geçiren kazazede grupları arasında, kazanın yaşandığı günlerdeki ortalama nem miktarı bakımından istatistiksel olarak anlamlı farkın olmadığı anlaşılmaktadır ( $p>0,05)$. Diğer bir deyişle günlük ortalama nem miktarındaki farklılık geçirilen kazanın şiddetini etkilememektedir. Hafif, orta ve ağır şiddetli kaza geçiren kazazede grupları arasında, kazanın yaşandığı günlerdeki ortalama hava basınç değeri bakımından istatistiksel olarak anlamlı farkın sorgulandı̆̆ı ANOVA çıktısı Tablo 11'de verilmiştir.

Tablo 11. Kaza Şiddeti Gruplarının Kazanın Yaşandığı Günlerin Günlük Ortalama Hava Basıncı (hpa) Bakımından Karşılaştırıldığı ANOVA

\begin{tabular}{|c|c|c|c|c|c|c|}
\hline $\begin{array}{c}\text { Kaza } \\
\text { Mevsimi }\end{array}$ & Gruplar & $\begin{array}{l}\text { Kareler } \\
\text { Toplamı }\end{array}$ & $\begin{array}{l}\text { Serbestlik } \\
\text { Derecesi }\end{array}$ & $\begin{array}{c}\text { Kareler } \\
\text { Ortalaması }\end{array}$ & $\mathrm{F}$ & $\begin{array}{c}\text { Anlamlılık } \\
\text { (p) }\end{array}$ \\
\hline \multirow{3}{*}{ İlkbahar } & Gruplar arası & 56,83 & 2 & 28,41 & 0,70 & 0,50 \\
\hline & Gruplar içi & 2314,21 & 57 & 40,60 & & \\
\hline & Toplam & 2371,04 & 59 & & & \\
\hline \multirow{3}{*}{ Yaz } & Gruplar arası & 17,60 & 2 & 8,80 & 0,75 & 0,48 \\
\hline & Gruplar içi & 445,33 & 38 & 11,72 & & \\
\hline & Toplam & 462,93 & 40 & & & \\
\hline \multirow{3}{*}{ Sonbahar } & Gruplar arası & 137,82 & 2 & 68,91 & 2,47 & 0,10 \\
\hline & Gruplar içi & 1087,04 & 39 & 27,87 & & \\
\hline & Toplam & 1224,86 & 41 & & & \\
\hline \multirow{3}{*}{ Kış } & Gruplar arası & 489,76 & 2 & 244,88 & 4,43 & 0,02 \\
\hline & Gruplar içi & 2154,00 & 39 & 55,23 & & \\
\hline & Toplam & 2643,76 & 41 & & & \\
\hline
\end{tabular}

Tablo 11 incelendiğinde sadece kış mevsimindeki hafif, orta ve ağır şiddetli kaza geçiren kazazede grupları arasında, günlük ortalama hava basıncı bakımından istatistiksel olarak anlamlı farkın olduğu anlaşılmaktadır $F(2,39)=4,43, p<0,05$. Diğer bir deyişle kış aylarında günlük ortalama hava basıncındaki farklılık geçirilen kazanın şiddetini etkilemektedir. Kış mevsiminde oluşan bu istatistiksel olarak anlaml farkın hangi gruplar arasında meydana geldiği ve niteliğinin anlaşılabilmesi için Post Hoc (Tukey) analizi yapılmış ve test çıktısı Tablo 12'de verilmiştir.

\section{Tablo 12. Kış Mevsimi İçin Kaza Şiddeti Gruplarının Kış Mevsiminde Kaza Günü Günlük Hava Basıncı} Ortalamaları Bakımından Karşılaştırıldığı Post Hoc (Tukey) Testi

\begin{tabular}{|c|c|c|c|c|c|c|}
\hline \multirow{2}{*}{\multicolumn{2}{|c|}{ Kaza Şiddeti }} & \multirow{2}{*}{$\begin{array}{l}\text { Ortalamalar } \\
\text { Farkı }\end{array}$} & \multirow{2}{*}{ Standart Hata } & \multirow{2}{*}{ Anlamlılık (p) } & \multicolumn{2}{|c|}{$95 \%$ Güven Sınır Aralığı } \\
\hline & & & & & Alt & Üst \\
\hline \multirow{2}{*}{ Hafif } & Orta & $-0,27$ & 2,58 & 0,99 & $-6,55$ & 6,02 \\
\hline & Ağır & 9,66 & 3,41 & 0,02 & 1,36 & 17,96 \\
\hline \multirow{2}{*}{ Orta } & Hafif & 0,27 & 2,58 & 0,99 & $-6,02$ & 6,55 \\
\hline & Ağır & 9,92 & 3,67 & 0,03 & 0,99 & 18,86 \\
\hline \multirow{2}{*}{ A $\breve{g} ı r$} & Hafif & $-9,66$ & 3,41 & 0,02 & $-17,96$ & $-1,36$ \\
\hline & Orta & $-9,92$ & 3,67 & 0,03 & $-18,86$ & $-0,99$ \\
\hline
\end{tabular}

Tablo 12 incelendiğinde kıș mevsiminde kaza günü günlük hava basıncı arttıkça daha ağır şiddette iş kazası geçirildiği anlaşılmaktadır. Hafif, orta ve ağır şiddetli kaza geçiren kazazede grupları arasında, kazanın yaşandığı günlerdeki ortalama rüzgâr hızı bakımından istatistiksel olarak anlamlı farkın sorgulandığı ANOVA çıktısı Tablo 13'te verilmiştir. 
Tablo 13. Kaza Şiddeti Gruplarının Kazanın Yaşandığı Günlerdeki Günlük Ortalama Rüzgâr Hızı (m/sn) Bakımından Karşılaştırıldı̆̆ı ANOVA

\begin{tabular}{|c|c|c|c|c|c|c|}
\hline $\begin{array}{c}\text { Kaza } \\
\text { Mevsimi }\end{array}$ & Gruplar & $\begin{array}{l}\text { Kareler } \\
\text { Toplamı }\end{array}$ & $\begin{array}{c}\text { Serbestlik } \\
\text { Derecesi }\end{array}$ & $\begin{array}{c}\text { Kareler } \\
\text { Ortalaması }\end{array}$ & $\mathrm{F}$ & $\begin{array}{l}\text { Anlamlılık } \\
\text { (p) }\end{array}$ \\
\hline \multirow{3}{*}{ İlkbahar } & Gruplar arası & 3,16 & 2 & 1,58 & 1,54 & 0,22 \\
\hline & Gruplar içi & 58,34 & 57 & 1,02 & & \\
\hline & Toplam & 61,50 & 59 & & & \\
\hline \multirow{3}{*}{ Yaz } & Gruplar arası & 5,51 & 2 & 2,76 & 3,85 & 0,03 \\
\hline & Gruplar içi & 27,19 & 38 & 0,72 & & \\
\hline & Toplam & 32,70 & 40 & & & \\
\hline \multirow{3}{*}{ Sonbahar } & Gruplar arası & 3,57 & 2 & 1,79 & 2,01 & 0,15 \\
\hline & Gruplar içi & 34,60 & 39 & 0,89 & & \\
\hline & Toplam & 38,17 & 41 & & & \\
\hline \multirow{3}{*}{ Kış } & Gruplar arası & 6,30 & 2 & 3,15 & 3,68 & 0,03 \\
\hline & Gruplar içi & 33,42 & 39 & 0,86 & & \\
\hline & Toplam & 39,72 & 41 & & & \\
\hline
\end{tabular}

Tablo 13 incelendiğinde yaz ve kıș mevsimindeki hafif, orta ve ağır şiddetli kaza geçiren kazazede grupları arasında, günlük ortalama rüzgâr hızı bakımından istatistiksel olarak anlamlı farkın olduğu anlaşılmaktadır $F(2,38)=3,85$, $p<0,05, F(2,39)=3,68$, $\mathrm{p}<0,05$. Diğer bir deyişle yaz ve kış mevsimlerinde günlük ortalama rüzgâr hızındaki farklılık geçirilen kazanın şiddetini etkilemektedir. Yaz ve kış mevsimlerinde oluşan bu farkın hangi gruplar arasında meydana geldiği ve niteliğinin anlaşılabilmesi için Post Hoc (Tukey) analizi yapılmış ve test çıktısı Tablo 14'te verilmiştir.

Tablo 14. Yaz ve Kış Mevsimleri İçin Kaza Şiddeti Gruplarının Kaza Günü Günlük Ortalama Rüzgâr Hızındaki (m/sn) Ortalamaları Bakımından Karşılaştırması Post Hoc (Tukey)Testi

\begin{tabular}{|c|c|c|c|c|c|c|c|}
\hline \multirow{2}{*}{ Mevsim } & \multirow{2}{*}{\multicolumn{2}{|c|}{ Kaza Şiddeti }} & \multirow{2}{*}{$\begin{array}{l}\text { Ortalamalar } \\
\text { Farkl }\end{array}$} & \multirow{2}{*}{$\begin{array}{r}\text { Standart } \\
\text { Hata }\end{array}$} & \multirow{2}{*}{$\begin{array}{l}\text { Anlamlilık } \\
\text { (p) }\end{array}$} & \multicolumn{2}{|c|}{ 95\% Güven Sınır Aralığı } \\
\hline & & & & & & Alt & Üst \\
\hline \multirow{6}{*}{ Yaz } & \multirow{2}{*}{ Hafif } & Orta & 0,78 & 0,31 & 0,04 & 0,02 & 1,55 \\
\hline & & A $\breve{g}_{ı r}$ & $-0,28$ & 0,41 & 0,78 & $-1,28$ & 0,73 \\
\hline & \multirow{2}{*}{ Orta } & Hafif & $-0,78$ & 0,31 & 0,04 & $-1,55$ & $-0,02$ \\
\hline & & Ağır & $-1,06$ & 0,46 & 0,07 & $-2,19$ & 0,07 \\
\hline & \multirow{2}{*}{ Ağır } & Hafif & 0,28 & 0,41 & 0,78 & $-0,73$ & 1,28 \\
\hline & & Orta & 1,06 & 0,46 & 0,07 & $-0,07$ & 2,19 \\
\hline \multirow{6}{*}{ Kış } & \multirow{2}{*}{ Hafif } & Orta & 0,10 & 0,32 & 0,95 & $-0,68$ & 0,88 \\
\hline & & Ağır & $-1,06$ & 0,42 & 0,04 & $-2,10$ & $-0,03$ \\
\hline & \multirow{2}{*}{ Orta } & Hafif & $-0,10$ & 0,32 & 0,95 & $-0,88$ & 0,68 \\
\hline & & Ağgr & $-1,16$ & 0,46 & 0,04 & $-2,28$ & $-0,05$ \\
\hline & \multirow{2}{*}{ Ağır } & Hafif & 1,06 & 0,42 & 0,04 & 0,03 & 2,10 \\
\hline & & Orta & 1,16 & 0,46 & 0,04 & 0,05 & 2,28 \\
\hline
\end{tabular}

Tablo 14 incelendiğinde yaz mevsiminde rüzgâr hızındaki artışla birlikte iș kazasının şiddetinde azalma olduğu anlaşılmaktadır. Kış mevsiminde ise rüzgâr hızındaki artışla birlikte iş kazasının şiddetinde artma olduğu anlaşılmaktadır. 


\subsection{Kruskal-Wallis $H$ Testi Uygulaması}

Hafif, orta ve ağır şiddetli kaza geçiren kazazede grupları arasında, kazazedelerin son işyerindeki deneyimleri bakımından istatistiksel olarak anlamlı farkın sorgulandığı Kruskal-Wallis H Testi çıktısı Tablo 15'te verilmiştir.

Tablo 15. Kaza Şiddeti Gruplarının Son İşyerindeki Deneyimlerine Göre Karşılaş̧tırıldığı H Testi

\begin{tabular}{lc}
\hline & $\begin{array}{c}\text { Kazazedenin Son } \\
\text { İşyerindeki Deneyimi (gün) }\end{array}$ \\
\hline Ki-Kare & 1,74 \\
Serbestlik Derecesi & 2 \\
Anlamlılık (p) & 0,42 \\
\hline
\end{tabular}

Tablo 15 incelendiğinde hafif, orta ve ağır şiddetli kaza geçiren kazazede grupları arasında, kazazedelerin son işyerindeki deneyimleri ortalamaları bakımından istatistiksel olarak anlamlı farkın olmadığı anlaşılmaktadır ( $p>0,05)$.

Hafif, orta ve ağır şiddetli kaza geçiren kazazede grupları arasında kaza günleri toplam yağıș ortalamaları bakımından istatistiksel olarak anlamlı farkın sorgulandığı Kruskal-Wallis $\mathrm{H}$ testi çıkısı Tablo 16'da verilmiştir.

Tablo 16. Kaza Şiddeti Gruplarının Kaza Günleri Toplam Yağış Miktarına Göre Karşılaştırıldığı H Testi

Günlük Toplam Yağış (kg/m2)

\begin{tabular}{lc}
\hline Ki-Kare & 0,42 \\
Serbestlik Derecesi & 2 \\
Anlamllık (p) & 0,81 \\
\hline
\end{tabular}

Tablo 16 incelendiğinde hafif, orta ve ağır şiddetli kaza geçiren kazazede grupları arasında, kaza günleri toplam yağış ortalamaları bakımından istatistiksel olarak anlamlı farkın olmadığı anlaşılmaktadır $(\mathrm{p}>0,05)$.

\section{Sonuç ve Öneriler}

İstanbul Küçükçekmece Sosyal Güvenlik Merkezi sorumluluğundaki inşaat firmalarının 2015, 2016 ve 2017 yılı faaliyetlerinde meydana gelen iş kazalarından 185 tanesinin durumu kaza şiddeti bakımından istatistiksel anlamda incelenmiştir.

$\mathrm{Bu}$ bağlamda araştırmada kullanılan ANOVA ve Kruskal-Wallis $\mathrm{H}$ testi sonuçlarına göre inşaat faaliyetlerindeki iş kaza şiddetini etkileyen faktörler dört mevsim için ayrı ayrı değerlendirilmiştir. Böylece mevsimler bir kontrol değişkeni olarak kullanılmış ve kendi grubundaki her bir faktör üzerine eşit şekilde etki etmesi sağlanmıştır. Bu şekilde her bir faktörün farklı mevsimlerde ortaya çıan inşaat iş kazasının şiddeti üzerine etkisi sorgulanmıștır. Çalışmanın bu yönüyle literatürde bir ilk olduğu ve alanına yenilik getireceği değerlendirilmektedir.

Kazazedelere ait yaşın kaza şiddetini $\mathrm{p}<0,05$ düzeyinde etkilemediği bulgusuna ulaşılmıştır. $\mathrm{Bu}$ sonucun bazı araştırmacıların (Salminen, 2004; Arquillos vd., 2012; Cheng vd., 2012; Frickmann vd., 2012; Dumrak vd., 2013; Alizadeh vd., 2015) tarafından yapılan çalışmalar ile uyum içinde olmadığı görülmüştür. Ancak, analiz sonuçları $\mathrm{p}<0,10$ düzeyinde incelendiğinde ise literatürle uyumlu hale geldiği; yaşın kaza şiddetini kış aylarında etkilediği ve yaştaki artışla beraber kaza şiddetinin azaldığı görülmüştür.

Kış aylarında meydana gelen iş kazalarında kazazedenin genel iş deneyimi arttıkça kaza şiddetinin azaldığı bulgusuna ulaşılmıştır. Bu bulgunun literatürdeki bazı araștırmacılar (Akboğa ve Baradan, 2019; Dumrak vd., 2013) tarafindan mevsimsel ayrım yapılmaksızın iș kaza şiddeti ve çalışan deneyimi arasındaki ilişkinin araştırıldı ̆̆ çalışmalar ile uyum içinde olduğu görülmüştür.

Diğer mevsimlerde ise genel iş deneyimi ile iş kazası şiddeti arasında istatistiksel bakımdan anlamlı bir ilişki olmadığı tespit edilmiștir. Tüm mevsimlerde, kazazedelerin son işyerindeki deneyimlerinin kaza şiddetini etkilemediği bulgusuna ulaşılmıştır.

Tüm mevsimlerde, işyerindeki çalışan sayısının kaza şiddetini etkilemediği bulgusuna ulaşılmıştır. Bu sonucun bazı araştırmacıların (McVittie vd., 1997; Fabiano vd., 2004; Chi vd., 2005; Lopez vd., 2008; Sa vd., 2009; Cheng vd., 2010) çalışmaları ile uyum içinde olmadığı görülmüştür. $\mathrm{Bu}$ uyumsuzluğa; işyerindeki çalışan sayısı bakımından araştırmalardaki farklılığının veya diğer çalışmalarda mevsimsel farklılığa dikkat edilmemesinin neden olabileceği düşünülmektedir.

Tüm mevsimlerde kazanın yaşandığı günlerin ortalama hava sıcaklığının kaza şiddetini etkilemediği bulgusuna ulaşılmıştır. Analiz sonuçları $\mathrm{p}<0,10$ düzeyinde incelendiğinde ilkbahar aylarında ortam sıcaklığının kaza şiddetini etkilediği görülmüştür. Bu bakımdan ilkbahardaki ortalama sıcaklık artışının kaza şiddetini artırdığı belirlenmiştir. $\mathrm{Bu}$ seviyedeki sonuçların bazı araştırmacıların (Rameezdeen ve Elmualim, 2017; Ricco vd., 2018; Varghese vd., 2019) bulguları ile uyum içinde olduğu görülmüştür. 
Tüm mevsimlerde, kazanın yaşandığı gün ortalama nem miktarının kaza şiddetini etkilemediği bulgusuna ulaşılmıştır.

Kış aylarında meydana gelen iş kazalarında, günlük ortalama hava basıncı kazanın şiddetini etkilemektedir. Kaza günü günlük hava basıncı arttıkça daha ağır şiddette iş kazası geçirildiği anlaşılmaktadır.

Yaz ve kış mevsimlerinde meydana gelen iş kazalarında günlük ortalama rüzgâr hızının kaza şiddetini etkilediği bulgusuna ulaşılmıştır. Yaz mevsiminde rüzgâr hızındaki artışların iş kazası şiddetini azalttı̆̆l, kış mevsiminde ise rüzgâr hızındaki artışların iş kazası şiddetini arttırdığı bulgusuna ulaşılmıştır.

Tüm mevsimlerde, kaza günleri toplam yağıș ortalama miktarının kaza şiddetini etkilemediği bulgusuna ulaşılmıștır.

Geçmiş çalışmalarda; nem miktarı, günlük ortalama hava basıncl, günlük ortalama rüzgâr hızı ve günlük toplam yağış miktarı ile iş kazası şiddeti arasındaki ilişkilerin araştırıldığı bir çalışma bulunamadığı için bir sonuç karşılaştırması da yapılamamıştır.

İşyerlerindeki tehlikelerin belirlenmesi ve risklerin hesaplanmasında, çalışanların kişisel faktörlerine ek olarak mevsimsel ve iklimsel faktörlerin de göz önünde bulundurulmasının, oluşabilecek iş kazalarına ait şiddetin azaltılmasına katkı sağlayacağı değerlendirilmektedir. Bu kapsamda; genç ve tecrübesiz çalışanların tehlikesiz işlerde ve daha tecrübeli çalışanların gözetiminde çalıştırılmaları, ilkbaharın ilk döneminde havaların ısınmasıyla beraber çalışanlarda oluşabilecek rehavet ve tehlikeli davranışların önüne geçilmesi, kışın havaların soğuk ve rüzgârlı olduğu günlerde çalışmaların kapalı ve sıcak ortamlarda yürütülmesi tavsiye edilebilir.

İș kazaları ile ilgili yapılacak araştırmalarda diğer faktörlerle beraber iklim faktörlerini de kullanılması tavsiye edilebilir.

Son dönemdeki akademik çalışmalarda iş kazalarının şiddetini etkileyen faktörlerin belirlenmesi, iş kazası ve iş kazası şiddeti model çalışmalarına sıklıkla rastlanmaktadır. Bu türdeki akademik çalışmalarda kullanılan verilerin güncel, mikro ve yeterli sayıda olması analiz sonuçlarının güvenilirliği bakımından oldukça önemlidir. $\mathrm{Bu}$ nedenle verilerin araștırmacılarla paylaşılmasının gelecekte yapılacak çalışmaların niteliğini de artıracağı değerlendirilmektedir. Bu bağlamda bașta Türkiye İstatistik Kurumu olmak üzere Sosyal Güvenlik Kurumu'nun söz konusu verileri anonimleştirerek araştırmacılarla paylaşmaları önerilmektedir.

\section{Çıkar Çatışması}

Yazarlar tarafından herhangi bir çıkar çatışması beyan edilmemiştir.

\section{Kaynaklar}

Abdelhamid, T., Everett, (2000). Identifying Root Causes of Construction Accidents. Journal of Construction Engineering and Management, 126(1), 52-60.

Ahmad, S., Iraj, M., Abbas, M. ve Mahdi, A. (2016). Analysis of Occupational Accidents Induced Human Injuries: A Case Study in Construction Industries and Sites. Journal of Civil Engineering and Construction Technology, 7(1), 1-7.

Akboğa, Ö. (2014). İnşaat İş Kazalarında Lojistik Regresyon ile Kaza Şiddetinin Modellenmesi. Doktora Tezi, Ege Üniversitesi Fen Bilimleri Enstitüsü, İzmir, 180.

Akboğa, Ö., Baradan, S. (2019). Identifying Factors that Contribute to Severity of Construction Injuries using Logistic Regression Model. Teknik Dergi, 31(2), 9919-9940.

Aksorn, T., Hadikusumo, B. (2008). Critical Success Factors Influencing Safety Program Performance in Thai Construction Projects. Safety of Science, 46(4), 709-727.

Aksöyek, A. R. (2002). Türk İnşaat Sektöründe İş Kazalarının ve İş Güvenliği Sorununun İncelenmesi. Yüksek Lisans Tezi, İstanbul Teknik Üniversitesi Fen Bilimleri Enstitüsü, İstanbul, 166.

Ali, A., Amin, M., Husin, A. (2019). Key Success Factors for Safety Programs Implementation in Indonesian Construction Projects. International Journal of Civil Engineering and Technology (IJCIET), 10(2), 1385-1394.

Alizadeh, S. S., Mortazavi, S. B., Mehdi Sepehri, M. (2015). Assessment of Accident Severity in The Construction Industry Using The Bayesian Theorem. International Journal of Occupational Safety and Ergonomics, 21(4), 551-557.

Alomari, K., Gambatese, J. (2015). Ironworker Perspectives on Accident Causes and Improving Safety Planning. CIB W099. Belfast: Ulster University. 
Arquillos, A. L., Romero, J. C., Gibb, A. (2012) Analysis of Construction Accidents in Spain, 2003-2008. Journal of Safety Research, 43(5-6), 381-388.

Baradan, S., Akboğa, Ö., Çetinkaya, U., Usmen, M. A. (2016). Ege Bölgesindeki İnşaat İş Kazalarının Sıklık ve Çapraz Tablolama Analizleri. IMO Teknik Dergi, 27(1), 7345-7370.

Bilir, S. (2015). İnşaat Projelerinde Süresel Planlama ile Bütünleşik Aktivite Tabanlı İş Güvenliği Risk Değerlendirme Yöntemi. Doktora Tezi, İstanbul Teknik Üniversitesi Fen Bilimleri Enstitüsü, İstanbul, 182.

Caner, G., Eren, Ö., Oral, H. V., Heperkan, H. (2020). Yeni Bir Risk Değerlendirme Yöntemiyle Tersane İşletmelerinin Sinıflandırılması. Business \& Management Studies: An International Journal, 8, 232-254.

Cheng, C. W., Leu, S. S., Cheng, Y. M., Wu, T. C. (2012). Applying Data Mining Techniques to Explore Factors Contributing to Occupational Injuries in Taiwan's Construction Industry. Accident Analysis \& Prevention, 48, 214-222.

Cheng, C. W., Leu, S. S., Lin, C. C., Fan, C. (2010). Characteristic Analysis of Occupational Accidents at Small Construction Enterprises. Safety Science, 48(6), 698-707.

Chi, C. F., Chang, T. C., Ting, H. I. (2005). Accident Patterns and Prevention Measures for Fatal Occupational Falls in The Construction Industry. Applied Ergonomics, 36(4), 391-400.

Choi, S. D., Guo, L., Kim, J., Xiong, S. (2019). Comparison of Fatal Occupational Injuries in Construction Industry in The United States, South Korea, and China. International Journal of Industrial Ergonomics, 71, 64-74.

Çakan, H. (2012). Analysis and Modeling of Roofer and Steel Worker Fall Accidents. Doktora Tezi, Wayne State University, Michigan, 167.

Çolak, B., Etiler, N., Biçer, Ü. (2004). Fatal Occupational Injuries In The Construction Sector In Kocaeli, Turkey, 1990-2001. Industrial Health, 42(4), 424-430.

Dumrak, J., Mostafa, S., Kamardeen, L., Rameezdeen, R. (2013). Factors Associated With The Severity of Construction Accidents: The Case of South Australia. Construction Economics and Building 13(4), 32-49.

Engin, S., Öztürk, O., Öner, A. (2009). İnşaat İşlerinde Meydana Gelen İş Kazalarının Sebep ve Sonuçlarının İrdelenmesi: İş Sağlığı ve Güvenliği Sempozyumu.

Fabiano, B., Currò, F., Pastorino, R. (2004). A Study of The Relationship Between Occupational Injuries and Firm Size and Type in The Italian Industry. Safety Science, 42(7), 587-600.

Fang, D., Chen, Y., Wong, L. (2006). Safety Climate in Construction Industry: A Case Study in Hong Kong. Journal of Construction Engineering and Management, 132(6), 573.

Fass, S., Yousef, R., Liginlal, D., Vyas, P. (2017). Understanding Causes of Fall and Struck-By Incidents: What Differentiates Construction Safety in The Arabian Gulf Region? Applied ergonomics, 58, 515-526.

Frickmann, F., Wurm, B., Jeger, V., Lehmann, B., Zimmermann, H., Exadaktylos, A. K. (2012). 782 Consecutive Construction Work Accidents: Who İs At Risk? A 10-Year Analysis From A Swiss University Hospital Trauma Unit. Swiss Medical Weekly, 1-7.

Gambatese, J. A., Rajendran, S., Behm, M. G. (2007). Green Design \& Construction Understanding The Effects On Construction Worker Safety and Health. Professional Safety, 52(5).

Gambatese, J., Hinze, J. (1999). Addressing Construction Worker Safety in The Design Phase: Designing for Construction Worker Safety. Automation In Construction, 8(6), 643-649.

Gillen, M., Baltz, D., Gassel, M., Kirsch, L. and Vaccaro, D., (2002). Perceived Safety Climate, Job Demands, and Coworker Support Among Union and Nonunion Injured Construction Workers. Journal of Safety Research, 33(1), 33-51.

Gürcanlı, E. (2013). İnşaat Sektöründe Gerçekleșen Ölüm ve Yaralanmaların Analizi. TTB Mesleki Sağlık ve Güvenlik Dergisi, 13(48), 20-29.

Huang,. (2003). The Owner's Role in Construction Safety. Doktora Tezi, University of Florida. 
Im, H. J., Kwon, Y. J., Kim, S. G., Kim, Y. K., Ju, Y. S., Lee, H. P. (2009). The Characteristics of Fatal Occupational Injuries in Korea's Construction Industry, 1997-2004. Safety Science, 47(8), 11591162.

Karadağ, T. (2017). Bir İnşaat Firmasının Yaşanmış İş Kazalarının Oluş Şekli Açısından İncelenmesi ve Sebep Sonuç İlişkileri. Yüksek Lisans, Yeni Yüzyıl Üniversitesi Sağlık Bilimleri Enstitüsü, İstanbul, 95.

Kazan, E. E. (2013). Analysis of Fatal and Nonfatal Accidents Involving Earthmoving Equipment Operators And on-Foot Workers. Doktora Tezi, Wayne State University, Michigan, 176.

Koç, M., Akbıyık, N. (2011). Türkiye'de İş Kazalarının Maliyetleri ve Çözüm Önerileri. Akademik Yaklaşımlar Dergisi, 2(2), 129-175.

Koyun, M. (2013). Trakya Üniversitesi Sağlık Araştırma ve Uygulama Merkezi Acil Servisi'ne Yüksekten Düşme Nedeniyle Başvuran Hastaların Analizi. Uzmanlık Tezi, Trakya Üniversitesi, Tıp Fakültesi, Edirne, 90.

Lingard, H., Rowlinson, S. M. (2005). Occupational Health and Safety in Construction Project Management. Spon Press, London and New York.

López, M. AC., Ritzel, D. O., Fontaneda, I., Alcantara, O. JG. (2008). Construction Industry Accidents in Spain. Journal of Safety Research, 39(5), 497-507.

McVittie, D., Banikin, H., Brocklebank, W. (1997). The Effects of Firm Size on Injury Frequency in Construction. Safety Science, 27(1), 19-23.

Müngen, M. (1993). Türkiye'de İnşaat İş Kazalarının Analizi ve İş Güvenliğinin Sorunu. Doktora Tezi, Ístanbul Teknik Üniversitesi Fen Bilimleri Enstitüsü, İstanbul, 419.

Nordlöf, H., Wiitavaara, B., Högberg, H. and Westerling, R. (2017). A Cross-Sectional Study of Factors Influencing Occupational Health and Safety Management Practices in Companies. Safety Science, 95, 92-103.

Öztürk, T. (2019). İş Kazalarını Etkileyen Faktörlerin Çok Değişkenli İstatistiksel Yöntemlerle Değerlendirilmesi. Doktora Tezi, İstanbul Aydın Üniversitesi Fen Bilimleri Enstitüsü, İstanbul, 173.
Öztürk, T., Caner, G. (2021). Türkiye' de Tüm Sektörlere Ait 2018 Yılı İş Kazalarının ve Kaza Sonucu Yaşam Kaybının Kazazede Yaşı Bakımından Değerlendirilmesi. Avrupa Bilim ve Teknoloji Dergisi, 22, 410-415.

Öztürk, T., Eren, Ö., Oral, H. V. (2021) Türkiye'de İş Kazaları ve Makroekonomik Faktörlerin İlişkisi: Zaman Serisi Analizi. Academic Platform Journal of Engineering and Science, 9(1), 165-173.

Pallant, J. (2017). SPSS Survival Manual (SPSS Kullanma Klavuzu, SPSS ile Adım Adım Veri Analizi). Anı Yayıncılık, Ankara.

Parsons, T. J., Pizatella, T. J., Collins, J. W. (1986). Safety Analysis of High Risk Injury Categories Within The Roofing Industry. Professional Safety, 31(6), 13-17.

Rameezdeen, R., Elmualim, A. (2017). The Impact of Heat Waves on Occurrence and Severity of Construction Accidents. International Journal of Environmental Research and Public Health, 14(1), 70.

Riccò, M., Vezzosi, L., Balzarini, F., Odone, A., Signorelli, C. (2018). Air Temperatures and Occupational İnjuries in The Construction Industries: A Report From Northern Italy (20002013). Industrial Health. 58(2), 182-192.

Sa, J., Seo, D. C., Choi, S. D. (2009). Comparison of Risk Factors for Falls From Height Between Commercial And Residential Roofers. Journal of Safety Research, 40(1), 1-6.

Salminen, S. (2004). Have Young Workers More İnjuries Than Older Ones? An İnternational Literature Review. Journal of Safety Research, 35(5), 513-521.

Sawacha, E., Naoum, S., \& Fong, D. (1999). Factors Affecting Safety Performance on Construction Sites. International Journal of Project Management, 17(5), 309-315.

Sayıcı, F., Öztürk, T. (2020). Türkiye'de 2019'da Gösterime Girmiş Filmlerin Sosyal Gereklilik ve Sektör Ekonomisi Bakımından İncelenmesi. Business \& Management Studies: An International Journal, 8(5), 4413-4437. 
Sosyal Güvenlik Kurumu İş Kazası ve Meslek Hastalıkları İstatistikleri. (2018). Erişim adresi: http://www.sgk.gov.tr/wps/portal/sgk/tr/kuru msal/istatistik/sgk_istatistik_yilliklari. Erişim tarihi : 07 Mayıs 2021.

Sosyal Güvenlik Kurumu İş Kazası ve Meslek Hastalıkları İstatistikleri. (2019). Erişim adresi: http://www.sgk.gov.tr/wps/portal/sgk/tr/kuru

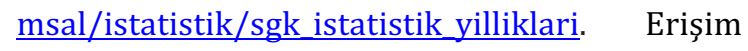
tarihi : 07 Mayıs 2021.

Sosyal Güvenlik Kurumu (2010). Sosyal Sigorta İşlemleri Yönetmeliği Ankara: Resmi Gazete (27579 sayılı)

Stewart, M. A. (2009). GRE Answers to the Real Essay Questions. Peterson's.

Karagüven, Ü., M. (1997), İş Kazaları ile Stres, Kaygı ve Öfke Kavramları Arasındaki İlişkinin İncelenmesi: 9 Türk ve 2 İngiliz Tekstil Fabrikasında Yapılan Bir Araștırma. Doktora Tezi, İstanbul Üniversitesi Sosyal Bilimler Enstitüsü, İstanbul, 224.

Varghese, B. M., Barnett, A. G., Hansen, A. L., Bi, P., Nairn, J., Rowett, S., Nitschke, M., Hanson-Easey, S., Heyworth, J. S., Sim, M. R., Pisaniello, D. L. (2019). Characterising the Impact of Heatwaves on Work-Related Injuries and Illnesses in Three Australian Cities Using a Standard Heatwave Definition- Excess Heat Factor (EHF). Journal of
Exposure Science \& Environmental Epidemiology, 29(6), 821-830.

Yardım, N., Çipil, Z., Vardar, C., Mollahaliloğlu, S. (2007). Türkiye İş Kazaları ve Meslek Hastalıkları: 2000-2005 Yılları Ölüm Hızları. Dicle Tıp Dergisi, 34(4), 264-271. 


\title{
ZEYTİN TARIMINDA ÇALIŞAN İŞÇİLERİN ÇALIŞMA DURUŞLARININ REBA YÖNTEMİ İLE ANALIZİ
}

\author{
Hüsre Gizem AKALP ${ }^{1 *}$, Uğur SAKLANGIÇ² , Sevil ÇIRAKOĞLU³
}

${ }^{1}$ Bursa Uludağ Üniversitesi, Teknik Bilimler MYO, Mülkiyet Koruma ve Güvenlik Bölümü ORCID No: http://orcid.org/0000-0001-7412-9112

2 Bursa Uludağ Üniversitesi, Teknik Bilimler MYO, Mülkiyet Koruma ve Güvenlik Bölümü ORCID No: http://orcid.org/0000-0003-3891-2948

3 Bursa Uludağ Üniversitesi, Teknik Bilimler MYO, Mülkiyet Koruma ve Güvenlik Bölümü ORCID No: http://orcid.org/0000-0001-6124-0954

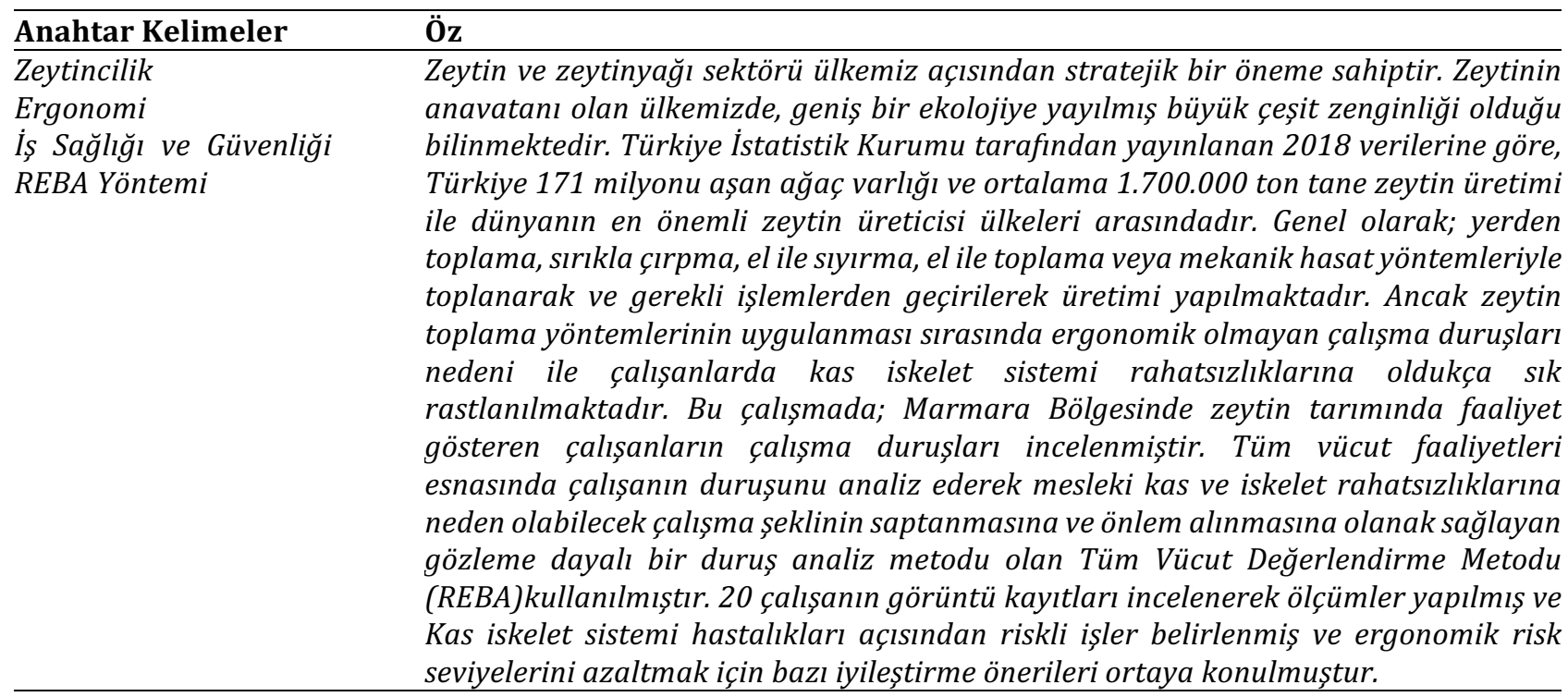

\section{ANALYSIS OF WORKING STOPS OF WORKERS WORKING IN OLIVE AGRICULTURE BY} REBA METHOD

\begin{tabular}{l} 
Keywords \\
\hline Olives \\
Ergonomics \\
Occupational Health \\
and Safety \\
REBA Method
\end{tabular}

Araștırma Makalesi

Başvuru Tarihi

Kabul Tarihi

\begin{abstract}
The olive and olive oil sector has a strategic importance for our country. In our country, which is the homeland of olives, it is known that there is a great variety of varieties spread over a wide ecology. According to 2018 data published by the Turkish Statistical Institute, Turkey is among the most important olive producing countries in the world, with over 171 million trees and an average olive production of 1,700,000 tons. Generally; It is produced by collecting from the ground, whisking with a pole, scraping by hand, collecting by hand or by mechanical harvesting methods and passing through the necessary processes. However, musculoskeletal disorders are quite common in workers due to non-ergonomic working postures during the application of olive picking methods. In this study; Working postures of employees operating in olive farming in the Marmara Region were examined. The Whole-Body Evaluation Method (REBA), an observation-based posture analysis method, was used to analyze the posture of the employee during all body activities, to determine the working style that may cause occupational musculoskeletal disorders and to take precautions. By examining the image records of 20 employees, measurements were made and risky jobs in terms of musculoskeletal diseases were determined and some improvement suggestions were put forward to reduce ergonomic risk levels.
\end{abstract}

$\begin{array}{lll} & \text { Research Article } & \\ : 02.07 .2021 & \text { Submission Date } & : 02.07 .2021 \\ 10.08 .2021 & \text { Accepted Date } & : 10.08 .2021\end{array}$




\section{Giriş}

Zeytin ve zeytinyağı yaklaşık 8000 yıl öncesinden bu yana dünyaya güzellik, sağlık ve lezzet pınarı olarak hizmet vermekte ve barışın sembolü olarak kabul edilmektedir. Zeytin ağacı, ağır büyüyen fakat uzun yaşayan, gövdesi çürümeye karşı çok dayanıklıdır. Zeytin ağacının meyvesi başlarda yeşil, daha sonra mor ve siyah renge dönüşür. Zeytin; su, protein, yağ, selüloz, fosfor, kükürt, kalsiyum, klor, demir, bakır, manganez A, $C$ ve $E$ vitaminlerinden meydana gelir. 100 gram zeytinde 224 kalori, 100 gr zeytinyağında 30 miligram E vitamini bulunmaktadır. Zeytin ağacı ortalama 700 ile 2000 yıla kadar yaşamaktadır. Killi, kireçli ve su geçirebilen topraklarda yetişmekte, engebeli ve yamaç, fakat llık rüzgârlı yerleri sevmektedir. Anavatanı Anadolu olan zeytin ağacı, Ege adalarından Yunanistan, İtalya, Fransa ve İspanya'ya kadar uzanmış ve buradan da Kuzey Afrika'ya geçmiştir. Dünya genelindeki zeytin yetiştiriciliğinin dağılımı incelendiğinde \% 90’lık bir kısmının Akdeniz havzası, geriye kalan kısmının ise Latin Amerika ülkelerinde yayıldığı gözlenmiştir (Sakar ve Ünver,2011:20).

Ülkemiz açısından da stratejik bir öneme sahip olan zeytin üretimi, Ege, Marmara ve Akdeniz bölgelerinin kıyı kesimlerinde yoğunlaşmaktadır.

Uluslararası Zeytin Konseyi verilerine göre zeytinyağı üretiminde 2018-2019 döneminde İspanya 1,6 milyon ton ile zeytinde olduğu gibi ilk sırada yer alırken onu 265 bin ton ile İtalya, 225 bin ton ile Yunanistan, 200 bin ton ile Fas ve 183 bin ton ile Türkiye izlemektedir. Dünya toplam zeytinyağı üretimi 3,1 milyon ton olarak gerçekleşirken İspanya yaklaşık \%51'ini tek başına yapmaktadır. Türkiye ise küresel zeytin üretiminin yaklaşı $\% 15,8$ 'sini gerçekleştirmektedir (Ekonomik Araştırmalar Şubesi, 2021).

Ülkemiz açısından bu kadar değerli olan bir ürünün üretilmesi aşamasında yer alan ürünün toplanması işlemi esnasında çalışanlarda uygun olmayan çalışma duruşları söz konusu olmaktadır. Ürünün toplanması aşaması iklim ve çalışma koşulları nedeniyle oldukça değişken bir ortamdır. Farklı sektörlerde teknolojik ilerlemeler kaydedilmesine rağmen, bu alanda iş yükü çok yüksek kalmaktadır.

Kas-iskelet sistemi bozuklukları, yüksek fiziksel iş yükleri nedeniyle zeytin toplama çalışanlarında yaygındır. İşin çoğu elle yapılması ve yoğun işgücü kullanımı gerektiren zeytin toplama işinde uygun olmayan çalışma duruşları, kas-iskelet sistemi rahatsızlıklarına neden olduğu gibi üretimin verimsizliğine de neden olmaktadır. $\mathrm{Bu}$ bozuklukların başlangıcıyla doğrudan ilişkili olarak not edilebilecek faktörler arasında tekrarlayan hareketler, zararlı duruşlar ve ağır yükler bulunmaktadır.

Kas iskelet sistemi rahatsızlıkları (KISR), özellikle endüstrileşmiş ülkelerde karşı karşıya kalınan yaygın sağlı sorunlarından biridir. KISR verimlilikte azalmaya, iş günü kayıplarına ve tazminat ödemelerinde artışa neden olmakla birlikte ülke ekonomilerini de olumsuz yönde etkilemektedir (Erciş ve ark., 2014).

Vücut eklemlerinin çalışma için en güvenli ve rahat duruş olan normal duruştan anlamlı düzeyde sapması, uygun olmayan çalışma duruşu olarak tanımlanmaktadır. Bu duruştan sapmalar, çalışanda yorgunluğa ve ağrıya neden olmanın yanı sıra çalışanı iş yapmaya ara vermek zorunda bırakmaktadır (Akay ve ark., 2003).

KİSR etiyolojisinde genel olarak çalışma ortamında karşılaşılan tekrarlayıcı hareketlerin sürekli yapılması, vücudun uygun olmayan pozisyonlarda uzun süre kalması ve titreşim maruziyeti ile ortaya çıkan birikimli travmaların etkisi söz konusudur (Bilir, 2011; Kaya ve Akalp, 2017). İşe bağlı KISR kişinin gösterdiği fiziksel çaba ile ilişkili olup, dünyanın her tarafında karşılaşılan yaygın sağlık problemlerinden biridir (İçağasıoğlu ve ark., 2015).

KİSR kaslarda, sinirlerde, tendonlarda, bağ dokularda, birleșme noktalarında ve disklerde meydana gelen yaralanma ve bozukluklar sonucu oluşan hastalıklardır (Akay ve ark., 2003). Bu hastalıklar eğilme, tutma, bükme ve uzanma gibi hareketler nedeniyle oluşmaktadır (Kahya, 2020). Bu hareketler günlük yaşam içerisinde süreklilik olmadan yapıldıklarında ciddi zararları olmamakla birlikte, iş yaşamında sürekli tekrar durumu söz konusu olduğunda, güç gerektirdiğinde ve hızlı yapıldığında oldukça zararlı hale gelmektedirler. KİSR, ayrıca, statik çalışma pozisyonları, sıcaklık derecesi düşük ortamlarda çalışma, aşırı iş yükü, titreşim, sıkışma, çalışma ortamının ergonomik prensiplere göre tasarlanmaması gibi risk faktörleri nedeniyle ortaya çıkmaktadır (Kaya, 2015; Özel ve Çetik, 2010).

Çalışma hayatında KİSR; bel, boyun ve üst ekstremite (el bileği, el, dirsek ve omuz) hastalıkları olarak sinıflandırılmaktadır. Bel ve sırt ağrıları, kas zorlanması ve incinmesi, boyun tutulması, boyun fitığı, bel fitığı, karpal tünel sendromu, gergin boyun sendromu ve kas kuvveti dengesizlikleri işten kaynaklanan başlıca kas iskelet sistemi rahatsızlıklarıdır. KİSR'da en sık tutulan bölgeler bel, boyun, eller, el bilekleri, 
dirsekler ve omuzlardır (Esen, Fı̆̆lalı, 2013'den aktaran Atıcı ve ark.; Kaya ve Özok, 2017).

KISR önleyebilmenin en önemli yolu bireylerin karşı karşıya kaldığı ergonomik tehlikelerin belirlenmesi ve bu kapsamda ergonomik risk değerlendirmelerinin yapılmasıdır. Ergonomik iyileştirmelerin ve düzenlemelerin nasıl yapılması gerektiği, ergonomik risk değerlendirmeleri sonucu belirlenmelidir. Literatür incelendiğinde, ergonomik riskleri değerlendirmek için birbirinden farklı özellikte pek çok yöntem bulunduğu görülmektedir. $\mathrm{Bu}$ yöntemler, çalışırken çalışanın duruşunu değerlendirmek ya da yaptığı işin unsurlarını ele almak üzere tasarlanmışlardır. Ergonomik riskler değerlendirilirken yapılan işe uygun yöntemlerin seçilmesi gerekmektedir.

$\mathrm{Bu}$ çalışma kapsamında, zeytin tarımında çalışanlara yönelik KİSR risk düzeylerinin Hızlı Tüm Vücudu Değerlendirme (Rapid Entire Body Assessment, REBA) yöntemi ile tespit edilmesi amaçlanmıştır. Gözleme dayalı yöntemlerden olan REBA, çalışma pozisyonlarıyla ilişkili risklerin ölçülmesinde ve çalışma duruşu esnasında çalışanın bütün vücudunun değerlendirilmesinde kullanılan yaygın bir araçtır.

Zeytin işletmelerinde çalışanların ergonomik risk değerlendirmeleri açısından ilgili literatür incelendiğinde, farklı yöntemlerle gerçekleştirilmiş bir iki çalışma haricinde REBA yönteminin uygulandığı bir çalışma ile karşılaşılmamıştır.

Bu kapsamda Marmara Bölgesinde zeytin hasadı yapan yirmi (20) çalışanın görüntü kayıtları incelenerek ölçümler yapılmış ve kas iskelet sistemi hastalıkları açısından yaptıkları riskli işler belirlenmiş, ergonomik risk seviyelerini azaltmak için bazı iyileştirme önerileri ortaya konulmuştur.

\section{Bilimsel Yazın Taraması}

Hignett ve McAtamney tarafından geliştirildikten sonra kullanışlılığı fark edilen REBA yöntemi ile yapılmıș birçok çalışma bulunmaktadır.

REBA yöntemini incelemek açısından literatür taraması yapıldığında birçok farklı sektörde ve uygulamada tercih edilen bir yöntem olduğu görülmektedir. Bu kapsamda REBA yöntemi kullanılarak yapılan bazı çalışmalara yer verilmiștir.

Sa ve arkadaşları 2006 yılında, diş hekimliği çalışmalarında duruş zorluklarının değerlendirilmesi amacı ile RULA (Rapid Upper Limb Assessment) ve REBA yöntemlerinin karşılaştırılmasını yapmışlardır. Paraiba Federal
Üniversitesinde diş hekimliği öğrencilerinin duruş zorluklarını iş pozisyonlarını araştırarak ve fotoğraflayarak, analiz etmişlerdir. Bu şekilde 39 durus pozisyonu analiz edilmiş ve sonuçlarda RULA yöntemi ile hesaplamalarında duruş skoru 5.5, REBA skoru ise 7,1 olarak değerlendirmişlerdir. Bulunan risk skoru değerlendirilmiş ve orta derecede riskler için küçük değişiklikler yapılmasına ihtiyaç duyulmuştur. Sonuç olarak diş hekimleri işlerinin büyük bir bölümünde vücutlarının üst kısmını hareket ettirdikleri için RULA yöntemi ile daha sağlıklı analizlere ulaşılacağı görüşüne varmışlardır (Sa ve ark., 2006).

2011 yilında Scott Rud tarafından, bir şirkette yüksekliği dikkate alarak kargo kutularının güncel kaldırma teknikleri ile ergonomik risk analizi REBA ve RULA yöntemleri ile gerçekleşmiştir. Yüksekte bulunan kargo kutuları ve bu kutuların uygunsuz kaldırılmaları nedeniyle gerçeklesen sakatlanma oranları sanayi ortalaması ile karşılaştırılmış ve daha yüksek olduğu görülmüştür. $\mathrm{Bu}$ araştırma sonucunda, kargo kutularının kaldırılmasından dolayı oluşan risk faktörlerinin azaltılması gerektiği ve çalışanları eğitmek için kullanılan kişisel koruyucu donanım ve idari kontrollerin belirlenmesi gerektiği ortaya çlkmıştır (Rud.,2011).

Tarım, ormancılık faaliyetlerinde REBA uygulamaları incelendiğinde, Das ve Gangopadhyay'in kas-iskelet bozukluklarını değerlendirmek için patates yetiştiricilerinde REBA'yı uyguladığı görülmektedir. Bu çalışmanın sonuçlarına göre, çalışanlarda en çok etkilenen vücut bölgelerinden birinin bel bölgesi olduğu belirlenmiştir (Das ve Gangopadhyay,2015).

Das ve arkadaşları benzer bir çalışmayı 10-16 yaş aralığındaki 120 patates yetiştiricisini inceleyerek REBA ve OWAS yöntemi ile gerçekleștirmiş ve aynı şekilde bel bölgesinin en çok etkilenen (\%98) bölge olduğunu belirlemişlerdir (Das ve ark., 2013).

Yöntem ayrıca Silver ve arkadaşları tarafından domates yetiştiriciliğinde çalışan göçmen tarım işçilerine yönelik uygulanmış, bel ve sırt bölgesinin en fazla etkilenen bölge olduğu belirlenmiștir (Silver ve ark., 2014).

Riemer ve arkadaşları tarafından da güneybatı İsrail'de bulunan iki çiftlikteki seralarda biber ve domatesin kafeslenme ve hasat aşamalarına çalışan işçilerde yöntemin uygulanması sonucu, domates yetiştiriciliği için el ile kaldırılan kutuların ağırlığının en fazla 12 kg olmasının tarımda manuel iş süreçlerinde karşı karşıya kalınan kas-iskelet yaralanmalarını azaltabileceği belirtilmiştir (Riemer ve ark., 2016). 
Deros ve arkadaşları tarafından da palmiye yağı üreticilerinde bu yöntemin kullanıldığı görülmektedir. Çalıșmanın sonuçlarına göre, çalışanların \%81,4'ü elle taşıma görevlerini gerçekleștirmek için sağlık ve güvenlik bilincine sahiptir ve doğru yöntemlerden haberdardır. Ancak \%87,1'i bel ağrısı ve \%94,3'ü sırt ağrısı yaşamaktadır (Deros ve ark., 2016).

$\mathrm{Bu}$ uygulamaların haricinde REBA yöntemi, Pal tarafından 2018 yılında pirinç yetiştiriciliğinde değerlendirilmiştir. Pirinç ekimi işinde çalışan kadın yetiștiricilerin postural stresini ve kasiskelet bozukluğu (MSD) prevalansını değerlendirmeyi amaçlayan çalışmada postural stres, OVAKO Çalışma Duruşları Analiz Sistemi (OWAS), Hızlı Tüm Vücut Değerlendirmesi (REBA), Hızlı Üst Ekstremite Değerlendirmesi (RULA) ve Hızlı Maruz Kalma Kontrol Listesi (QEC) yöntemleriyle ve ayrıca ağırlık merkezi ölçülerek değerlendirilip karşılaştırılmıştır (Pal,2018).

Ülkemizde Adana ve Mersin bölgesinde seracılık sektöründe çalışanların karşılaştığı ergonomik risklerin değerlendirilmesi amacı ile 08/09/2014 - 08/12/2014 tarihleri arasında iç ve diș mekân süs bitkisi yetiștiren sekiz seradan ve domates yetiştirilen iki seradan, 30/03/201503/04/2015 tarihleri arasinda da muz yetiştirilen yedi seradan toplanan verilerle 27 adet REBA analizi gerçekleştirilmiş ve çalışanların gerekli sağlık güvenlik bilincine sahip olmadıkları ve REBA skorları incelemelerinde önlem alınması gereken risk skorlarına sahip oldukları belirlenmiştir (Kır, 2015).

Enez ve Nalbantoğlu tarafından yapılan bir çalışmada, Ankara Orman Bölge Müdürlüğüne Bağlı Beypazarı Orman İşletme Müdürlüğü Beypazarı, Eğriova ve Kapaklı Orman ișletme Şefliklerinde 2013 yılı üretim faaliyetleri sırasında gerçekleştirilmiştir. Çalışan üretim postaları dikkate alınarak ormancılık faaliyeti gösteren 58 üretim çalışanı incelenerek kayıt altına alınmıştır. Sonuç olarak ormancılıkta üretim ișlerinin REBA "ya göre "orta" düzeyde olduğu değerlendirilmiştir (Enez ve Nalbantoğlu, 2015).

Tavşanlı Organize Sanayi Bölgesinde yer alan bir firmada, çalışanlarda zorlanmaya neden olan duruşların REBA yöntemi ile ergonomik analizini inceleyen Atıcı ve arkadaşları, işletmede gerçekleștirilen kablo demetleme konveyör hattında montaj işlemi açısından, ergonomik olmayan çalışma pozisyonu belirlemişlerdir. $\mathrm{Bu}$ çalışmada REBA skorunu 8 bulmuşlardır (Atıcı ve ark., 2015).
Denizli ilinde faaliyet gösteren büyük ölçekli bir firmanın üretim hattında çalışanların çalışma duruşlarının değerlendirilerek fiziksel iş yüklerinin belirlenmesi amacı ile uygulanan REBA yönteminde, işletme içerisinde 31 işin risk seviyesi orta ve daha yüksek bulunmuștur (Polat ve ark., 2017).

Aygün ve arkadaşları, tarafından narenciye hasadının ergonomik açıdan incelenmesi amacı ile yapılan bir çalışmada, özellikle ağaç dalları üzerinde yapılan kesme ve toplama işi ile narenciye dolu küfelerin sırtta taşınması, çalışanı en çok zorlayan işler olarak tespit edilmiştir (Aygün ve ark., 2018).

Erdemir ve Erdem, 2019 yılında, REBA yöntemi ile bir döküm atölyesindeki çalışma duruşlarının dijital insan modelleme tabanl ergonomik analizini yapmışlardır. REBA skoru 10 olarak oldukça yüksek seviyede bir sonuç vermiştir (Erdemir ve Erdem, 2020).

REBA ile ilgili bilimsel makaleleri ve bibliyografikleri inceleyen ve "Web of ScienceCore Colection" veri tabanının kullanıldığı Gutierrez ve arkadaşlarının yaptığı çalışmada REBA yönteminin kullanımı, bilgi, ülke, yıl ve dergi sektörleri açısından incelenmiştir. En çok imalat sektöründe (\%24.18) kullanılan yöntem, "Tarım, Ormancılık ve Balıkçılık" sektöründe $\% 21,98$ ve diğer faaliyetler kapsamında da $\% 19,78$ olarak belirlenmiștir (Gutierrez ve ark., 2020). Neredeyse her zaman diğer yöntemlerle birlikte kullanılabilen REBA, uygunsuz duruşları belirlemek açısından faydalı bir yöntemdir.

\section{Yöntem}

Bu çalışma, üniversite etik kurulunun 28.05.2021 tarih ve E-92662996-044-15435 sayılı onayı ile, Marmara Bölgesi, Bursa Gemlik ilçesinde zeytin hasadı yapan yirmi (20) çalışan ile gerçekleștirilmiştir. Çalışanların yaptıkları işler gözlenmiş, video kayıtları ve fotoğraflanmış görüntü kayıtları incelenerek REBA yöntemi ile ölçümler yapılmış ve kas iskelet sistemi hastalıkları açısından yaptıkları riskli işler belirlenmiştir. Beraberinde, ergonomik risk seviyelerini azaltmak için bazı iyileştirme önerileri ortaya konulmuştur. Yapılan çalışma ile ergonomik açıdan uygun olmayan çalışma pozisyonlarını belirlemek ve zeytin tarımında çalışanlar için ergonomik bir çalışma ortamı yaratmak amaçlanmıştır. Analiz yapılırken, zeytin toplama esnasındaki ortak işler göz önünde bulundurularak, tekrarlanmış duruş analizinden kaçınılmıştır. Çalışan öncelikle konu hakkında bilgilendirilerek ve normalde nasıl çalışıyor ise o şekilde çalıştığından emin olunarak araştırmacılar tarafından video kayıt ve fotoğraflamaları yapılmıştır. 20 çalışandan elde 
edilen skorlar araştırmacılar tarafından hazırlanan excel programında değerlendirilerek hesaplanmış ve sonuçlar tablo 2 de gösterilmiştir.

Hizmet sektörlerinde hatalı duruș pozisyonlarını belirleyebilmek amacı ile Hignett ve McAtamney (1998, 2000) tarafından geliştirilen REBA yöntemi özellikle elle yapılan taşıma, kaldırma işlemlerindeki riskleri hesaplamak için kullanışlı bir araçtır. Yöntem geliştirilirken ergonomist ve fizyoterapistlerden oluşan bir ekip tarafından 600'den fazla vücut duruşu örneği toplanarak kodlanmıştır. Ekibin amacı, statik ve dinamik duruşa bağlı yüklenme faktörleri ve yerçekimi destekli üst ekstremite pozisyonu kavramlarını birleştiren bir yöntem oluşturmaktır (Hignett ve McAtamney, 2000). REBA yöntemiyle hem dinamik hareketler hem de sabit durușlar analiz edilebilmektedir.

Bu yöntemde, analiz edilmek istenilen duruş veya hareketin neden olduğu toplam risk, sayısal olarak ifade edilebilir. Riski sayısal olarak ifade edebilmenin en büyük avantajı, analiz edilen duruştaki özel hareket ve duruşların ayrı ayrı meydana getirecekleri risk ve tehlikeli durumlarını belirtmektir. Belirtilen her bir hareket veya durus üst ve alt vücut için açllara ayrılarak toplam skor, boyun, gövde ve alt ve üst uzuvların pozisyonlarının kombinasyonu ile hesaplanır. Yönteme dahil edilen diğer faktörler ise kaldırılacak yükün kolaylık derecesi, yük üzerindeki kavrama şekli, hareketin ne sıklıkta yapıldığı, hareket sırasında vücudun sabit durması veya hareket ettiğinde aynı zamanda dönme, bükülme olup olmadığıdır (Kocabaş, 2009; Sue ve McAtamney, 2000).

Yöntem, çalışma duruşlarını sayısal olarak elde etmeyi sağlamaktadır. REBA yöntemi, bir çalışma duruşu esnasında boyunda, gövdede, üst kollarda, bacaklarda, alt kollarda ve bileklerde ortaya çıkan eklem bükme hareketi (fleksiyon) ve eklem germe hareketine (ekstansiyon) bağlı çalışanın maruz kaldığı yüklere karşılık olarak 1 ile 15 arasında değişen bir skor ile belirlenmektedir. Bu sayede analiz edilmek istenen duruş ve hareket sayısal olarak elde edilir. Bu yönteme göre, bir çalışma duruşunun REBA skoru belirlenirken öncelikle vücut kısımları, A ve B Grubu olmak üzere ikiye ayrılır. A grubunu oluşturan uzuvlar gövde, boyun ve bacaklardır. B grubu ise üst kollar, alt kollar ve bileklerden meydana gelmektedir. REBA yöntemine göre sağ ve sol uzuvlar aynı zaman için değerlendirilmektedir.

"REBA durus puanlama tablolarına göre; gövde, boyun ve bacaklar A gurubunu, üst kol, alt kol ve bilek B gurubunu oluşturur. A grubunda belirlenen bu değere yük/kavrama skoru eklenir.
Yük/kavrama tablosuna göre verilecek değer, <5 $\mathrm{kg}$ ise 0 puan, $5-10 \mathrm{~kg}$ arası ise 1 puan, $>10 \mathrm{~kg}$ ise 2 puan, ani veya hızl kuvvet artışı var ise +1 puan şeklindedir. $B$ grubunda belirlenen değere kavrama skoru eklenir. Kavrama skoru 0 ile 3 arasındadır. Bu değerler, iyi bir tutma ve orta derecede kavrama gücü var ise 0 puan, el tutuşu uygun fakat ideal değil veya vücudun başka bir bölgesi ile kavrama uygun ise 1 puan, el tutuşu uygun değil fakat mümkün ise 2 puan, zor ve güvenli olmayan tutuş var ve tutma kolu yok ise veya vücudun başka bir bölgesini kullanarak uygun olmayan tutus ise 3 puan şeklindedir" (Inyang, 2012: 79; Stanton ve ark., 2009).

Elde edilen A ve B skorlarının C tablosunda birleştirilmesi ile $\mathrm{C}$ skoru belirlenir. Belirlenen $\mathrm{C}$ skoruna aktivite skor değeri eklenerek REBA skoru elde edilir. Aktivite skor değeri, bir veya birden fazla vücut bölgesi sabit ise +1 puan, kısa aralıklarla tekrar edilen işler var ise (yürüme hariç) +1 puan, yapılan iş duruşta hızlı ve büyük değişiklilere neden oluyorsa veya sabit olmayan zeminde çalışılıyorsa +1 puan eklenmesi şeklinde hesaplanır (Sue ve McAtamney, 2000: 204). REBA duruşları için excel tablosu, Fotoğraf 1 de gösterilmektedir.

REBA'nın bir iş örneklemesine dayanması, çalışma sırasındaki postürlerin sergilenme sıklığının tespit edilmesinin sağlanması, zeytin işinde çalışanların kas iskelet sisteminin işle ilgili risk faktörlerinin zorlanma analizinde kullanılması, verilerin kolaylıkla gözlem yoluyla elde edilmesi ve kâğıt kalem kullanılarak analiz edilebilmesi, ayrıca uygulamanın kolay bir yöntem oluşu nedeni ile zeytin tarımında çalışanlar için kullanılabilirliğini göstermektedir.

\section{Fotoğraf 1. REBA Duruşları için Excel Tablosu}

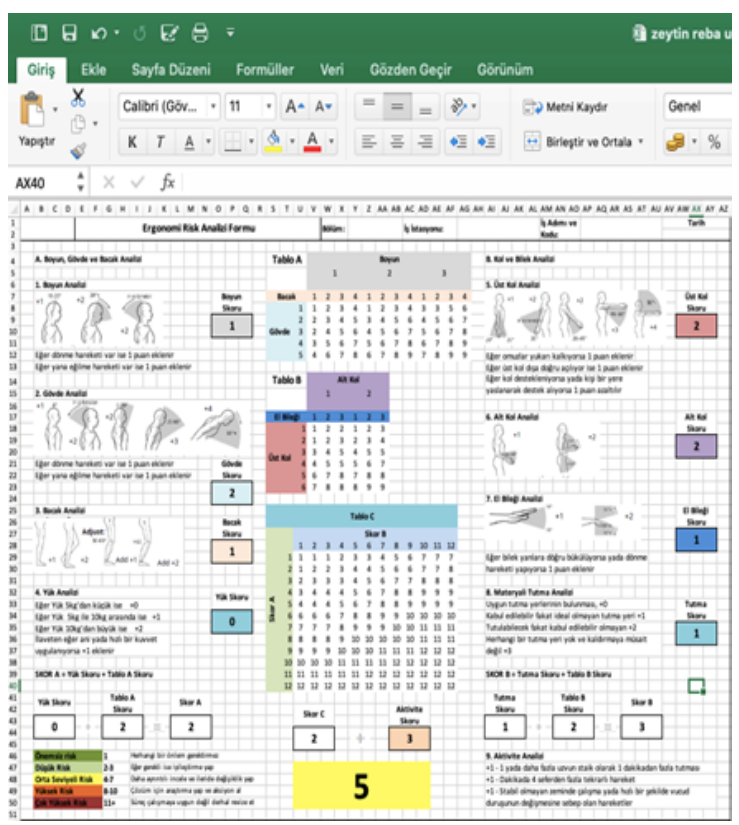



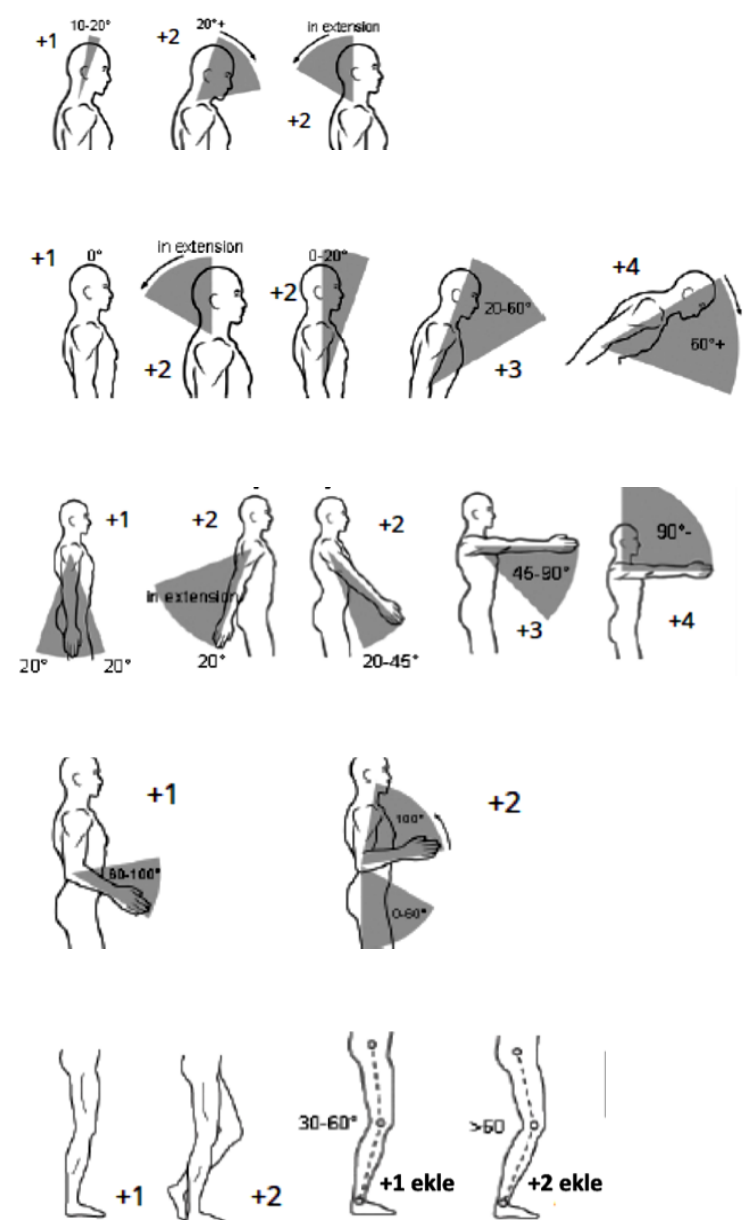

Şekil 1. REBA Yönteminde Kullanılan Kol, Bilek, Boyun Ve Gövdenin Duruş Pozisyonuna Ait Tanımlamaları (Aygün ve ark., 2018).

Sonuçta ortaya çıan REBA Skoru, Tablo 1'de verilen Risk Eylem Karar tablosundan kontrol edilerek, risk için alınacak önlemin aciliyet durumu belirlenir (Karwowski ve Marras, 1999: 8-7).

Tablo 1. Risk Eylem Karar Tablosu

\begin{tabular}{|c|c|c|c|}
\hline Derece & REBA Skoru & Risk Seviyesi & Önlem \\
\hline 0 & 1 & inmal Edilebilir & Gerekli Değil \\
\hline 1 & $2-3$ & Düşük & Gerekli olabilir \\
\hline 2 & $4-7$ & Orta & Gerekli \\
\hline 3 & $8-10$ & Yüksek & Kısa zaman içerisinde Gerekli \\
\hline 4 & $11-15$ & Çok Yüksek & Hemen Gerekli \\
\hline
\end{tabular}

\section{Bulgular}

Zeytin hasadının doğru zamanda ve doğru metot seçilerek yapılması hem zeytin ve zeytinyağının miktarını ve kalitesini belirlediği gibi hem de ağacın sağlı̆̆ını etkileyerek sonraki yıllardaki verimini de belirlemektedir. Zeytin toplama işlemi sofralık ve yağlık olarak iki farklı şekilde gerçekleşmektedir. Elle ve el tırmıkları ile yapılan zeytin toplama işinde zeytin kabuğunun zarar görmemesi ve etli kısmının da ezilmemesi gerekir. Toplama işleminde meydana gelebilecek olumsuz bir durum zeytinin piyasa değerini düşürür.

Ağaçtan elle veya tırmık yardımı ile toplanan zeytinler çuvallar içerisinde değil, zeytin naklinde kullanılacak plastik kasalarda taşınmaktadır. Fakat zeytin çalışanının ergonomik olmayan duruşlarda çalışması, kas iskelet sistemi rahatsızlıkları ve çalışan maliyeti yönünden de negatif etkiler oluşturmaktadır. Elle toplamada günlük toplanan miktar, çalışan başına 65 - 70 kg'a düşmektedir.

Marmara Bölgesi, Bursa Gemlik ilçesinde zeytin hasadı yapan yirmi (20) çalışan ile gerçekleştirilen bu çalışmada, zeytin hasadı yapan kişilerin fotoğraflarından bazıları örnek olması amacı ile aşağıda fotoğraf 2 ve 3 'de verilmiştir. Çalışanlar zeytin toplama işi esnasında uzanma, dönme ve eğilme hareketleri yapmaktadırlar. Özellikle ağaç dalları üzerinde yapılan kesme ve toplama işi çalışanların zorlanmalarına neden olmaktadır.

\section{Fotoğraf 2. Zeytin Toplama Çalıșanı Örnek Duruşlar-1}
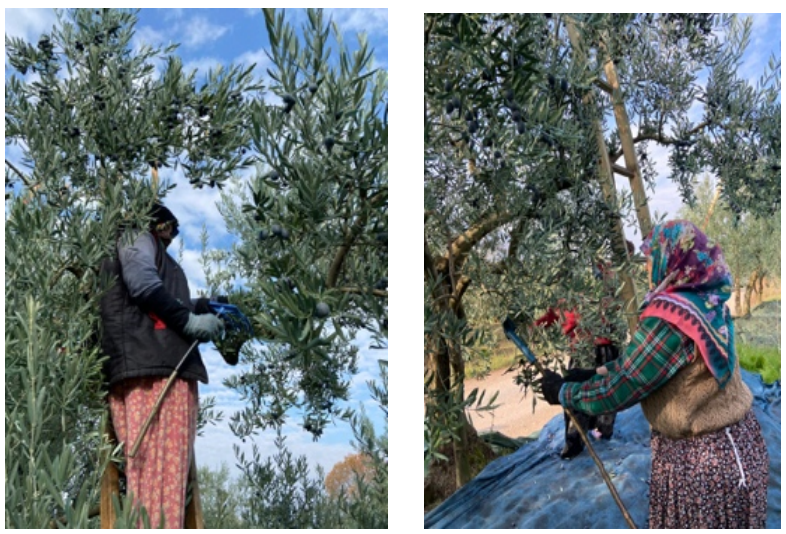

\section{Fotoğraf 3. Zeytin Toplama Çalışanı Örnek Duruşlar-2}
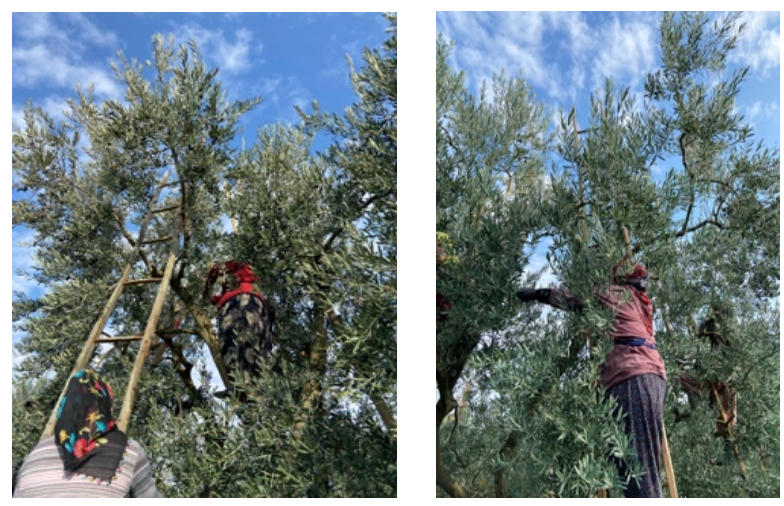

Tablo 2 de, gözlemlenen zeytin işçilerinin REBA skorları verilmektedir. 
Tablo 2. İşçilerin REBA Skorları

\begin{tabular}{|c|c|c|c|c|c|c|c|c|c|c|c|c|c|c|c|c|c|c|c|c|c|}
\hline \multirow[t]{2}{*}{ DURUŞLAR } & \multicolumn{21}{|c|}{ KișíLER } \\
\hline & 1 & 2 & 3 & 4 & 5 & 6 & 7 & & 8 & 9 & 10 & 11 & 12 & 13 & 14 & 15 & 16 & 17 & 18 & 19 & 20 \\
\hline Boyun & 2 & 3 & 3 & 3 & 3 & 1 & 3 & & 2 & 2 & 2 & 3 & 3 & 3 & 3 & 2 & 2 & 3 & 3 & 3 & 2 \\
\hline Bacak & 1 & 2 & 1 & 2 & 2 & 1 & 2 & & 1 & 1 & 1 & 1 & 2 & 2 & 2 & 1 & 1 & 2 & 2 & 1 & 1 \\
\hline Göyde & 2 & 3 & 4 & 3 & 3 & 2 & 3 & & 2 & 2 & 2 & 4 & 3 & 3 & 3 & 2 & 2 & 3 & 3 & 4 & 2 \\
\hline $\begin{array}{l}\text { Yük/ } \\
\text { Kuvvet }\end{array}$ & 0 & 0 & 0 & 0 & 0 & 0 & 0 & & 0 & 0 & 0 & 0 & 0 & 0 & 0 & 0 & 0 & 0 & 0 & 0 & 0 \\
\hline A SKORU & 3 & 6 & 6 & 6 & 6 & 2 & 6 & & 3 & 3 & 3 & 6 & 6 & 6 & 6 & 3 & 3 & 6 & 6 & 6 & 3 \\
\hline Alt Kol & 2 & 2 & 2 & 2 & 2 & 2 & 2 & & 2 & 2 & 2 & 2 & 2 & 2 & 2 & 2 & 2 & 2 & 2 & 2 & 2 \\
\hline Bilek & 2 & 2 & 2 & 2 & 2 & 1 & 2 & & 2 & $2:$ & 2 & 2 & 2 & 2 & 2 & 2 & 2 & 2 & 2 & 2 & 2 \\
\hline Ost Kol & 2 & 2 & 3 & 2 & 2 & 2 & 2 & & 2 & 2 & 2 & 3 & 2 & 2 & 2 & 2 & 2 & 2 & 2 & 3 & 2 \\
\hline Kavrama & 1 & 1 & 2 & 2 & 1 & 1 & 1 & & 1 & 1 & 1 & 2 & 1 & 2 & 2 & 1 & 1 & 1 & 1 & 2 & 1 \\
\hline B SKORU & 4 & 4 & 7 & 5 & 4 & 3 & 4 & & 4 . & 4 . & 4 & 7 & 4 & 5 & 5 & 4 & 4 & 4 & 4 & 7 & 4 \\
\hline CSKORU & 3 & 7 & 9 & 8 & 7 & 2 & 7 & & 3 & 3 & 3 & 9 & 7 & 8 & 8 & 3 & 3 & 7 & 7 & 9 & 3 \\
\hline $\begin{array}{l}\text { Aktivite } \\
\text { Skoru }\end{array}$ & 3 & 3 & 3 & 3 & 3 & 3 & 3 & & 3 & 3 & 3 & 3 & 3 & 3 & 3 & 3 & 3 & 3 & 3 & 3 & 3 \\
\hline $\begin{array}{l}\text { REBA } \\
\text { SKORU }\end{array}$ & 6 & 10 & 12 & 11 & 10 & 5 & & & 6 & 6 & 6 & 12 & 10 & 11 & 11 & 6 & 6 & 10 & 10 & 12 & 6 \\
\hline $\begin{array}{l}\text { RiSK } \\
\text { SEVIYESI }\end{array}$ & 0 & $\mathrm{Y}$ & ÇY & Cr & $\mathrm{Y}$ & 0 & r & & 0 & 0 & 0 & $C Y$ & $\mathrm{Y}$ & CY & ÇY & 0 & 0 & $\mathrm{Y}$ & $\mathrm{Y}$ & ç & 0 \\
\hline ONLEM & G & A & $\mathrm{H}$ & H & A & c & 19 & & G & G & G & H & A & H & H & G & G & A & A & H & G \\
\hline
\end{tabular}

Tablo 3. REBA Değer Ortalamaları

\begin{tabular}{|c|c|}
\hline & $\begin{array}{c}\text { REBA ANALi̇zi ORTALAMA } \\
\text { DEĞER }\end{array}$ \\
\hline Boyun & 2,9 \\
\hline Bacak & 1,45 \\
\hline Gövde & 2,75 \\
\hline Yük/kuvvet & 0 \\
\hline A skoru & 4,75 \\
\hline Alt kol & 2 \\
\hline Bilek & 1,95 \\
\hline Üst kol & 2,15 \\
\hline Kavrama & 1,3 \\
\hline B skoru & 4,55 \\
\hline C skoru & 5,8 \\
\hline Aktivite skoru & 3 \\
\hline Reba skoru & 8,8 \\
\hline Risk seviyesi & Yüksek \\
\hline Önlem & Acil önlem \\
\hline & \\
\hline & 4 \\
\hline
\end{tabular}

Tablo 3 incelendiğinde, A grubu parametreler içerisinde, boyun ve gövde parametresinin özellikle bazı duruşlarda yüksek değer aldığı dikkati çekmektedir. Yapılan gözlemlerde, çalışanların merdiven üzerinden eğilme burulma yani doğrudan belden hareket yapmalarının bu duruma sebep olduğu söylenilebilir.

B grubu parametrelerinin değerlendirilmesi ve gözlenmesi sonucu ise çalışanların budama makasları gibi antropometrik özellikleri yeterli olmayan ekipman kullanmasının bu parametreler üzerinde etken olduğu söylenebilir.

\section{Tartışma}

$\mathrm{Bu}$ çalışma çerçevesinde toplam 20 zeytin çalışanının zeytin toplama faaliyetleri gözlemlenerek kayıt altına alınmış ve çalışmalarına ait ergonomik değerlendirmelerde bulunulmuştur. Farklı koşullar altında gerçekleştirilen zeytin tarım işlerinde çalışanların çalışma duruşlarına yönelik durușlarının tüm vücut olarak değerlendirildiği postürleri sergileme sıklığı, iş örneklemesine dayanan REBA yöntemi kullanılarak değerlendirilmiștir. Bu yönteme göre zeytin tarım işçilerinin karşı karşıya kaldıkları risklerin "orta", "yüksek" ve "çok yüksek" düzeyde olduğu sonucuna ulaşılmıştır.

Araştırma sonuçlarına göre; özellikle ağaç dalları üzerinde yapılan kesme ve toplama işi, çalışanı en çok zorlayan işler olarak belirlenmiştir. Zeytin hasat ve sonrasında yapılan taşıma işi, çalışanların bedensel yükünü artırmaktadır. Bu tarz hasat ve taşıma işlemlerinin uzun dönemde kas iskelet sistemi rahatsızlıklarına yol açabileceği öngörülmektedir.

Genellikle taşınabilir merdivenler, bazı durumlarda da plastik kasaların üzerine çıkarak, düzgün olmayan zeminde çalışmak, plastik kasanın içe doğru kırılması, merdiven ile yapılacak çalışmalarda merdiven açısından alınması gereken önlemlerin alınmamış olması veya çalıșanın termal konfor şartlarının da etkisi ile baş dönmesi gibi sebeplerle geriye doğru düşmesi de yaralanma riski oluşturacağı için mutlaka dikkat edilmesi gereken konulardır.

Gerek yapılan gözlemler gerekse ölçümlerden elde edilen sonuçlar, zeytin tarım işlerinin ergonomik olmayan koşullarda gerçekleştiğini göstermektedir. İşin yapılışı esnasında çalışanların, eldiven haricinde herhangi bir KKD kullanmaması ve yağmur, soğuk vb. iklimsel olumsuz şartlara rağmen çalışmaya devam etmeleri de dikkate alınması gereken ergonomik riskler olarak değerlendirilmelidir.

REBA risk seviyesini düşürmek için, çalışanın antropometrik ölçülerine göre riskli bölgedeki zorlanmayı azaltacak alet, makineler tercih edilmeli, yapılan işe yönelik ve daha verimli çalışmayı sağlayacak şekilde iş ve metot etüdü çalışmaları yapılmalıdır.

REBA risk seviyesinin düşürülemediği durumlarda çalışan, fizik tedavi uzmanı tarafından belirli periyotlar içerisinde muayene edilmeli ve kas iskelet sistemini rahatlatıcı egzersizler yapılması teşvik edilmelidir. Uygun dinlenme aralarının verilmesi, çalışan rotasyonunun uygulamaya koyulması ve gün başında-sonunda germe gevşetme egzersizleri, kas 
iskelet sistemine yönelik riskleri azaltacak çok önemli iyileştirmeler olacaktır.

Diğer taraftan çalışanlara, uygun olmayan duruşların ve sonuçlarının neler olduğu verilen eğitimlerde anlatılmalı, gerekli ise eğitimler iş başlamadan önce tekrar hatırlatılmalıdır.

\section{Çıkar Çatışması}

Yazarlar tarafından herhangi bir çıkar çatışması beyan edilmemiştir.

\section{Kaynaklar}

Akay, D., Dağdeviren, M., Kurt, M. (2003). Çalışma Duruşlarının Ergonomik Analizi”. Gazi Üniversitesi Mühendislik Mimarlık Fakültesi Dergisi, 18(3): 73-84.

Atıcı, H., Gönen, D., Oral, A. (2015). Çalışanlarda Zorlanmaya Neden olan Duruşların Reba Yöntemi ile Ergonomik Analizi. Süleyman Demirel Üniversitesi Mühendislik Bilimleri ve Tasarım Dergisi 3(3):239-244, ÖS: Ergonomi2015, ISSN: 1308-6693

Aygün, İ., Çakmak, B., \& Alayunt, F. N. (2018). Narenciye Hasadının Ergonomik Açıdan İncelenmesi. Süleyman Demirel Üniversitesi Mühendislik Bilimleri ve Tasarım Dergisi, 6:312318.

Bilir, N. (2011). Meslek Hastalıkları Tanı, Tedavi Ve Korunma İlkeleri. Hacettepe Tıp Dergisi, 42(4): 142-157.

Das, B. Gangopadhyay, S. (2015). Prevalence Of Musculoskeletal Disorders And Physiological Stress Among Adult, Male Potato Cultivators Of West Bengal, India. Asia-Pac. J. Public Health, 27: 1669-1682.

Das, B., Ghosh, T., Gangopadhyay, S. (2013). Child Work in Agriculture In West Bengal, India: Assessment of Musculoskeletal Disorders And Occupational Health Problems. J. Occupation. Health, 55 (4): Erişim adresi: https://www.jstage.jst.go.jp/article/joh/advpub /0/advpub_12-0185-0A/_article/-char/ja/

Deros, B. M., Ali, M. H. Mohamad, D., Daruis, D.D.I. (2016). Ergonomic Risk Assessment On Oil Palm İndustry Workers. Iran. J. Public Health, 45, 44-51

Ekonomik Araştırmalar Şubesi (2021), Erişim Adresi: https://tim.org.tr/files/downloads/Ulke_Bilgi_N otlar\%C4\%B1/Zeytin\%20ve\%20Zeytinya $\%$ C $4 \%$ 9F\%C4\%B1\%20Hedef\%20Pazar $\% 20$ Bilgi $\% 20 \mathrm{~N}$ otu.pdf
Enez, K., Nalbantoğlu, S.S. (2015). Reba Yönteminin Ormancılık Faaliyetleri Açısından Değerlendirilmesi, Süleyman Demirel Üniversitesi Mühendislik Bilimleri ve Tasarım Dergisi 3(3), 127-131, ISSN: 1308-6693

Erdemir, F., Eldem C. (2020). Bir Döküm Atölyesindeki Çalışma Duruşlarının Dijital İnsan Modelleme Tabanlı REBA Yöntemi ile Ergonomik Analizi, Politeknik Dergisi, 23(2), 435-443

Eriş, H. Can, G.F., Fığlalı, N., (2014). Çalışma Duruşu Ve Kas-iskelet Sistemi Rahatsızlıkları. Erişim Adresi:

https://www.isgturkiye.com/konu/calismadurusu-ve-kas-iskelet-sistemi$\underline{\text { rahatsizliklari.1555/2014 }}$

Esen H., Fığlalı N. (2013). Çalışma Duruşu Analiz Yöntemleri Ve Çalışma Duruşunun Kas-İskelet Sistemi Rahatsızlıklarına Etkileri, SAÜ. Fen Bilimleri Dergisi. 17 (1),41-51.

Gutierrez-Hita, M., Galan-Gomez, M., Perez-Diaz, M., Ferre Callejon, J.A. (2020). An Overview of REBA Method Applications in the World. International Journal of Environmental Research and Public Health, Vol 17, Issue 8, 2635 Erişim Adresi: https://www.mdpi.com/1660-4601/17/8/2635

Hignett, S., McAtamney, L. (2000). Rapid Entire Body Assessment (REBA). Applied Ergonomics, 31, 201205.

İçağasıoğlu, A., Yumuşakhuylu, Y., Ketenci, A., Toraman, N.F., Maymak Karataş G., Kuru, Ö., Kirazlı, Y., Çapacı, K., Eriman, E. \& Haliloğlu, S. (2015). Burden Of Chronic Low Back Pain İn The Turkish Population. Turkish Journal of Physical Medicine and Rehabilitation, 61, 58-64

Kahya, E. (2020). Bir Metal Sanayi İşletmesinde Fiziksel Zorlanmaların Kas İskelet Sistemi Rahatsızlıklarına Etkisi, Endüstri Mühendisliği Dergisi, 31(2):148-158

Kaya, Ö. ve Akalp, G. (2017). İș Sağlığı ve Güvenliği Açısından Elle Taşıma İşlerinin Değerlendirilmesi (Tekstil ve Otomotiv Sektörü Örneği). "Ișs, Güç" Endüstri İlişkileri ve Insan Kaynakları Dergisi, 19 (2):75-90.ISSN: 2148-9874,

Kaya, Ö. (2015). Design of Work Place and Ergonomics in Garment Enterprises. Procedia Manufacturing 3, DOI: 10.1016/j.promfg.2015.07.921 Available online at www.sciencedirect.com p: 6437-6443.

Kaya, Ö. ve Özok, A. F. (2017). Tasarımda Antropometrinin Önemi. Süleyman Demirel Üniversitesi Mühendislik Bilimleri ve Tasarım Dergisi, Cilt 5, Özel Sayl, DOI: 10.21923/jesd.45182, e-ISSN: 1308-6693, s: 309316. 
Kır, İbrahim. (2015). Adana Ve Mersin Bölgesinde Seracılık Sektöründe Çalışanların Karşılaştığı Ergonomik Risklerin Değerlendirilmesi Çalışma ve Sosyal Güvenlik Bakanlığı \& Müdürlüğü, Erişim Adresi: https://ailevecalisma.gov.tr/media/1444/ibrahimki r.pdf

Inyang N., Al-Hussein, M, El-Rich, M, and Al-Jibouri S, (2012). Ergonomic Analysis and the Need for Its Integration for planning and assessing Management", 138:1370-1376.

Özel, E., Çetik, O., (2010). Mesleki Görevlerin Ergonomik Analizinde Kullanılan Araçlar ve Bir Uygulama Örneği. Dumlupınar üniversitesi Fen bilimleri Enstitüsü Dergisi, 22:41-56.

Pal, A. Dhara, P.C. (2018). Work Related Musculoskeletal Disorders and Postural Stress Of The Women Cultivators Engaged İn Uprooting Job Of Rice Cultivation. Indian J. Occup. Environ. Med. 2018, 22, 163-169. Erişim Adresi: https://www.ncbi.nlm.nih.gov/pmc/articles/PM C6309355/

Polat, O., Mutlu, Ö., Çakanel, H., Doğan, O., Özçetin E., Şen E., (2016). Bir Mobilya Fabrikasında Çalışan İşçilerin Çalışma Duruşlarının Reba Yöntemi İle Analizi. Mühendislik Bilimleri ve Tasarım Dergisi, 5,263-268, 2017 e-ISSN: 1308-6693

Riemer, R. Bechar, A. (2016). Investigation of Productivity Enhancement And Biomechanical Risks in Greenhouse Crops. Biosyst. Eng. 2016, 147, 39-50 Erişim Adresi: https://www.sciencedirect.com/science/article $\angle$ pii/S1537511015304475?casa_token=XX6zuT M8lHkAAAAA:P4enGBDxqNcHOvoEsgPoTc0mr7 sQGqy047QvnFWmbi1EdXFuzU1ixZM50JbERhf h9om70x8VSes

Rud, S. (2011). An Ergonomic Analysis Of Current Lifting Techniques in Height Restricted Cargo Bins At Company XYZ. The Graduate School University of Wisconsin-Stout.

Sa, F., Nascimento M.A., Melo A.C., Santos J.C. and Adissi P. J. (2006). Comparison of Methods Rula and Reba for Evaluation of Postural Stress in Odontological Services. 3rd International Conference on Production Research - Americas' Region.

Sakar E., Ünver H. (2011). Türkiye'de Zeytin Yetiştiriciliğinin Durumu Ve Ülkemizde Yapılan Bazı Seleksiyon Ve Adaptasyon Çalışmaları" HR.Ü.Z.F. Dergisi, 2011, 15(2): 19-25 J

Silver, K. Hoffman, K. Loury, S. Fethke, N.B. Liebman, A. Manz, N. Manock, S. Andino, A. Bradfield, M. Morrissette, D. (2014). Campus-community Partnership For Farmworkers' Health: Interventions For Tomato Workers İn
Tennessee. Prog. Community Health Partnersh. Res. Educ. Act. 8, 501-510. Erişim Adresi: https://muse.jhu.edu/article/575444/summary

Stanton N, Hedge A., Brookhuis K., Salas E., Hendrick $\mathrm{H}$, editors. "The Handbook Of Human Factors And Ergonomics Methods". Boca Raton, FL, USA: CRC Press

Waldemar K., William S. M. The Occupational Ergonomics Handbook. Fundamentals and Assessment Tools For Occupational Ergonomics". Second Edition:7-8. 


\title{
OTOMOTIV KULLANICILARINDA GÖRÜNTÜLEME YÖNTEMİ KULLANILARAK KONFOR AÇILARININ ARAŞTIRILMASI
}

\author{
Onur ÜLKER ${ }^{1 *}$, Mehmet Ali ALTIN², Mercan Haddad DERAFSHI ${ }^{3}$ \\ ${ }^{1}$ Eskişehir Teknik Üniversitesi, Mimarlık ve Tasarım Fakültesi, İç Mimarlık Bölümü \\ ORCID No: https://orcid.org/ 0000-0002-8108-6269 \\ 2 Eskişehir Teknik Üniversitesi, Mimarlık ve Tasarım Fakültesi, İç Mimarlık Bölümü Eskişehir \\ ORCID No: https://orcid.org/0000-0001-8992-7088 \\ 3 University of Tennessee at Martin, Department of Family and Consumer Sciences College of Agriculture \\ ORCID No: https://orcid.org/0000-0001-8887-2185
}

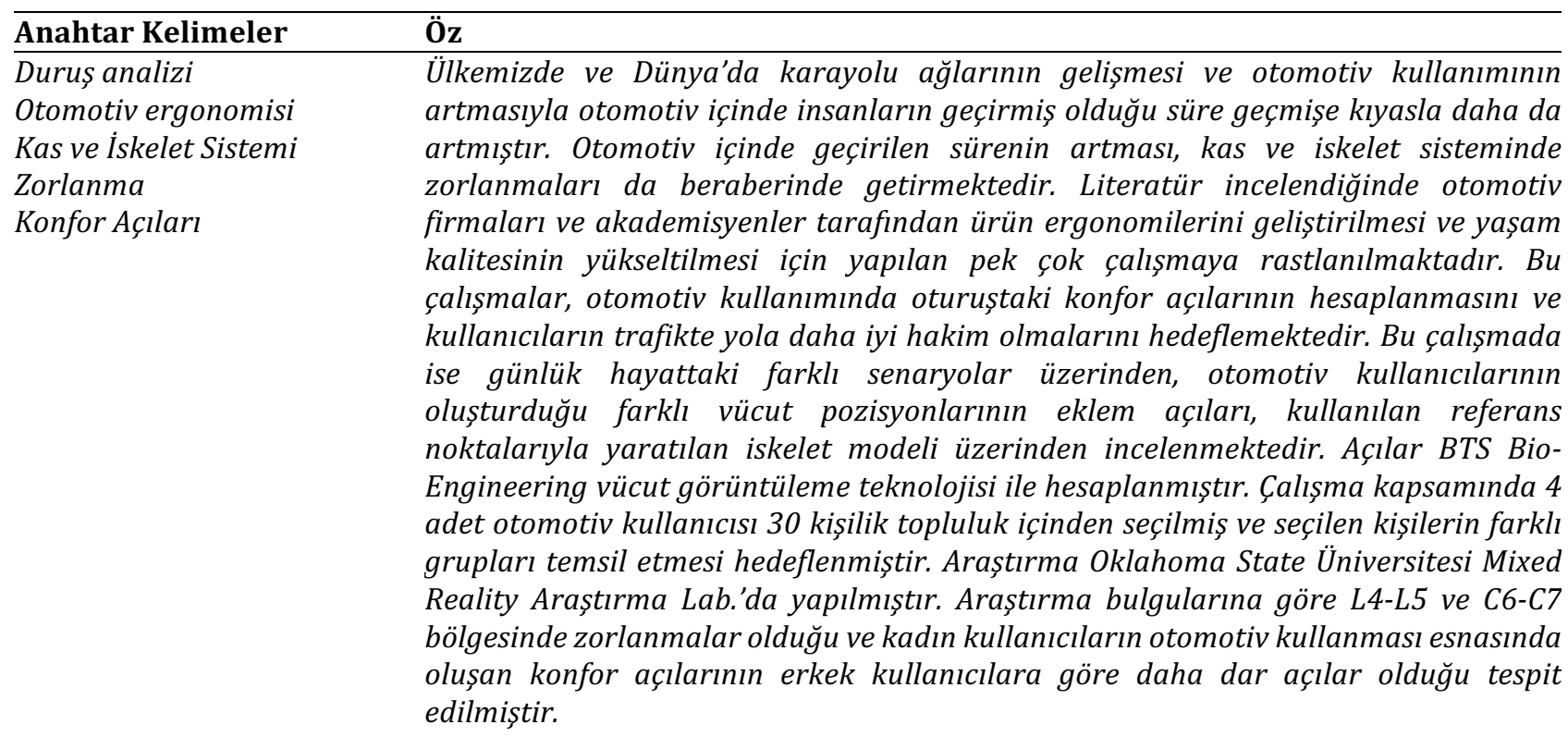

\section{INVESTIGATION OF COMFORT ANGLES BY USING} THE IMAGING METHOD

\begin{tabular}{ll}
\hline Keywords & Abstract \\
\hline Posture analysis & With the development of highway networks and the increase in automotive use in our \\
Car Ergonomics & country and in the world, the time spent in automotive vehicles has increased \\
Musculoskeletal System & compared to the past. Prolonged driving causes difficulties in the musculoskeletal \\
Stress & astem. Extensive literature conducted by automotive companies and academicians, \\
Comfort angles & assessed comfort angles in automotive use and addressed driver comfort in high traffic. \\
& In our study, different body angles were examined by creating a skeleton model. This \\
model represents automotive users who drive on a daily basis. Angles were calculated \\
by BTS Bio-Engineering software. Four participants were chosen from a group of 30 \\
drivers to represent diverse daily drivers. The study was conducted at the Mix Reality \\
Lab of Oklahoma State University. Research findings indicate that there are strains in \\
the lumbar spine (L4-L5), cervical spine (C6-C7), and that the comfort angles offemale \\
drivers are narrower than their male counterparts.
\end{tabular}

\begin{abstract}
Araştırma Makalesi
\end{abstract}
Başvuru Tarihi

Kabul Tarihi

\author{
Research Article \\ Submission Date \\ Accepted Date
}

\footnotetext{
*Sorumlu yazar e-posta: onurulker@eskisehir.edu.tr
} 


\section{Giriş}

Ergonomi bilimi insan-mekan ve insan-makine ilişkisinin en konforlu biçimde oluşturulmasını hedefler. Ergonomi biliminin temel amacı, insan makine ara kesitinde, insanları makinelere göre pozisyon almaktansa, makine tasarımının uygun hale getirilmesini sağlamaktır (Carayon and Smith 2000; Ulker, 2020).

Ergonomi bilimi imalat esnasında verilen işlerin çalışana göre planlanmasını hedefler böylelikle çalışanlarda oluşabilecek zorlanma ve stresin en az seviyeye indirilmesini sağlar. İşveren ve işçi sağlık harcamalarının da azalmasını sağlayarak ülke ekonomisine katkıda bulunur.

Otomotiv sektörü ile ilişkili iç mekan konfor çalışmalarının pek çoğu son atmış yılda yapılmıştır. $\mathrm{Bu}$ çalışmada ve literatürdeki araştırmalarda otomotiv kullanıcılarının kas ve iskelet sisteminde deformasyon ve zorlanmalar ile ilişkili sorunlara ve çözüm önerilerine değinilmiştir. Son yirmi yılda yapılan araştırmaların ise; otomotiv iç mekan tasarımı ve otomotiv koltukları ile ilişkili olduğu gözlemlenmektedir. İnsan anatomisine uygun olmayan koltuk tasarımları nedeniyle, uzun mesafe sürüşlerinde kas, iskelet ve endokrin sisteminde hasar oluştuğu gözlemlenmiştir (Zhang vd., 2000; Kaya ve Akalp, 2017; Straker ve Mekhora, 2000, Gowtham vd., 2020)

Bu çalışmada, daha önce yapılmış araștırmalardan farklı olarak, uzun süreli ve kısa süreli otomotiv kullanan kadın ve erkek sürücülerde konfor açılarının ve vücut duruşlarının dijital kameralar yardımı ile tespiti hedeflenmiştir.

Otomotiv kullanıcılarının duruşlarını incelemek için kızıl ötesi kameralar kullanılarak bilgisayar destekli görüntü yakalama analizi yapılmıştır.

Daha önce yapılmış olan çalışmalar incelendiğinde, görüntüleme tekniği kullanılarak otomotiv kullanıcılarının konfor açılarının araştırıldığı çalışmalarla karşılaşılmış ama cinsiyet ve yaş farkına göre ve farklı senaryolara göre araç içi duruşlarının incelendiği bir çalışma olmadığı gözlemlenmiştir. Literatüre katkı sağlamak amacıyla, farklı duruşlardaki konfor açıları araştırılmıştır.

Literatür incelendiğinde, araç iç mekan tasarımdaki en önemli 3 noktadan birisi olan koltuk tasarımı pek çok araştırmacının ilgisini çekmiştir (Zhang vd., 1996; Guenaelle 1995; Kamp 2002; Schmidt vd., 2014).

Otomotiv firmaları ve bağımsız araştırmacılar, konfor açılarına dayalı ergonomik oturma postürünü araştırmış ve belirli aralıkta konfor açıları önerilmiştir. Bu çalışmada da görüntüleme tekniği kullanılarak optimum açların bulunması hedeflenmiștir.

\section{Bilimsel Yazın Taraması}

Günümüzde, ticari kaygllar duyan otomotiv imalat firmaları, tasarladıkları araçlarda iç mekan tasarımlarını standart ölçüye sahip insan formuna göre planlamaktadır. Otomobillere ölçüsü ayarlanabilen koltuk, direksiyon gibi donanımlar yerleștirilmiş olsa bile, firmaların oluşturmuș olduğu bu aralık seviyeleri dünya üzerindeki bütün toplumlara hitap etmemektedir. İnsan ölçüleri farklı coğrafyalarda yaşayan toplumlara ve irklara göre farklılıklar göstermektedir. Alman ve Japon toplumunu örnek olarak gösterecek olursak, vücut ölçülerindeki ortalama farkı $30 \mathrm{~cm}$ gibi önemli büyüktedir (Eldem vd., 2019).

Otomotiv iç mekan tasarımı yapılırken, güvenli sürüş ve kullanıcı konforu öne çıkar. Doğru ölçülerde imal edilmemiş otomotivler kazaya neden olabilir. Sürücü koltuklarının yükseklik ayarları doğru olmalı, direksiyon simidi kullanıcıların dizine değmemeli, otomotiv kullanımı esnasında kullanıcıların göz mesafesi yolu tamamen tarayacak yükseklikte olmalıdır. Gaz, fren ve debriyaj pedallarının mesafesi iyi ayarlanmalı ve kullanıcıların antropometrik değerlerine uygun olmalıdır (Kaya ve Özok, 2017).

Otomotiv sektöründe çalışan firmalar, araç iç mekan ergonomisinin gelişimi ve sürüş konforunun artması için koltuk tasarımı ve araç kullanımı esnasındaki vücut duruşlarının araştırılmasına önem vermektedir (Gyi vd 1998; Guenaelle 1995; Andreoni vd., 1999). Otomotiv kullanımı esansında ve otomotiv tasarımındaki en önemli unsur kullanıcıların ve yolcuların vücut duruşudur (Gyi vd., 1998).

Araç iç konforu ve güvenliği ergonomik risk faktörlerine bağlıdır (Zhang vd., 1996). Otomotivler için iyi bir koltuk tasarlanmadığı durumda, bel ağrısı, sırt ağrısı ve boyun ağrısı kronikleşebilir ve kas iskelet sisteminde kalıcı problemlere yol açabilir (Grieco, 1998). Otomotiv koltuk tasarımı, konutlarda kullanılan koltuklara kıyasla daha kompleks ve zor kriterlere bağlıdır. Konutlarda kullanılan koltukla otomotivde kullanılan koltukların arasındaki en önemli fark ayakların pedallara basması gerekliliğidir. Araç kullanılırken sürekli gaz, debriyaj ve fren pedallarının kullanılmasından dolayı bel ve sırt kısmının mutlaka destekli olması gerekmektedir. Bel ve sırt kısımlarında yeterli destek olmadığ durumda vücut dengesi kaybolmakta sağ veya sol bölgelere fazla yük binmektedir.

Yük dağılımını dengelemek amacıyla koltuk tasarımında çeşitli eklentiler yapılmakta, koltuklara yapılan bu eklentiler sürücünün hareketlerini de kısıtlamaktadır. Hareketleri kısıtlanan sürücülerin belirli bir süre sonra sürüş güvenliği tehlikeye düşer. Otomotiv koltukları tasarlanırken sadece kullanıcıların nasıl rahat edeceği değil aynı zamanda kullanıcıların trafik içerisindeki görüș alanı ve araç 
içindeki kumanda yeteneğinin de kaybolmaması amaçlanmalıdır. (Chaffin ve Anderson 1991).

Araç kullanırken, lumbar bölgesinde deformasyonlar ve vücudun boyun ve sırt bölgelerinde ağrılar oluşmaktadır. Uzun yolculuklar sonunda sürekli gaz pedalına basmaktan bacak kaslarında kramplar ve kan dolaşımında bozulmalar yaşanmaktadır. Büyük şehirlerde dur-kalk yaparak ilerlenmesi durumunda omurilik disklerinde dejenerasyon oluşmaktadır. (Huang vd., 2004)

Literatür incelendiğinde, otomotiv sektöründe faaliyet gösteren Ar-Ge birimleri ve bağımsız araştırmacıların yaptığı 30'dan fazla yayınlanmış çalışmaya ulaşılmıştır. Çalışmaların pek çoğunda, sağlıklı vücut duruşunun araştırılmasında en doğru çalışma yönteminin eklemlerdeki açıların incelenmesi olduğu belirtilmiştir. Araç içi oturma duruşlarına dair ilk çalışma, 1940 yılında Lay ve Fisher tarafından yapılmıştır. Lay ve Fisher, çalışmasında 250 kişinin katılımıyla, kalça eklem açısının 104-107 derece arasında olması gerektiğini belirtmiştir. Konu hakkında en çarpıcı çalışma ise 1979 yılında Babbs tarafından yapılmış, bütün eklemlerin açılarının hesaplamaları ve ölçümleri yapılmıştır. Bu çalışma DIN 33408 standardına (1987) işı tutmuş ve optimum açılar standartlaşmıştır. Son yllarda ise dijital modelleme ile RAMSIS (1994) yazılımı oluşturulmuş, bilgisayar ortamında optimum açılar hesaplanmıştır (Lay ve Fisher 1940; DIN 33408; Seidl, 1997).

Graf vd., 1995 yılında, beş farklı günlük oturma eylemini incelemiş ve vücut duruşları hakkında araștırma yapmışlardır. Vücut duruşumuzun sağlıklı olması için eklemlerimiz vücudumuzun her hareketinde doğru pozisyonu alması gereklidir. Vücudumuz kas aktivitesi sırasında ligamentlerin (bağ) desteği ile stabil kalmak için, birçok kasın uyumlu çalışmasını sağlar. (Graf vd., 1995).

Andreoni vd., 2002 yılında otomotiv kullanımındaki vücut duruşlarının araştırılması ve kullanılan otomotiv koltuklarının üzerindeki basınç değerlerini ölçmek için metot analizi yapmışlardır. Araştırma kapsamında kullanılan görüntüleme yönteminde vücut üzerindeki 21 noktaya ve koltuk üzerinde 7 noktaya fosforlu işaretleyici toplar yerleştirilmiş, vücut üzerinde 14 farklı bölgenin açısı hesaplanmıştır. Leğen kemiği bölgesinin \%66, Lumbar bölgesinin \%27 ve sırt bölgesinin \%7 basınç uyguladığı iddia edilmiştir (Andreoni vd.,1999).

Zhou vd., 2017 yılında otomotiv kullanıcılarının rahatsız oldukları vücut açılarını araştırmışlardır. 2 farklı araç kokpit numunesini oluşturmuşlar, bu numunelerde, direksiyon açısı, koltuk açısı, pedalların yerleşimi ve açıları incelenmiş, ideal kullanım koşullarını önermişlerdir (Zhou vd., 2017). olan araç koltuğu tasarımı üzerinde çalışmalar yapmıştır. Çalışmalar BMW firmasıyla birlikte yürütülmüş, 21 katılımcı ile çalışılmış ve 3 farklı koltuk modeli tasarlanmıştır. Kullanıcıların otomotiv koltuğundan, rahatlık, şıklık, sportiflik ve kaza esnasında koruyucu olmasını beklediklerini ifade etmişlerdir (Kamp, 2012).

Vogt vd., 2005 yılında yaptıkları çalışmada, RAMSIS (Rechergestütztes Anthropometrisches Menschmodell zur Insassen-Simulation) yazılımının gelişim sürecini ve optimum açı değerlerini açıklamışlardır. RAMSIS yazılımı, Alman Ergonomi Enstitüsü ve Münih Teknik Üniversitesi tarafından geliștirilmiştir. RAMSIS yazılımının hedefi ergonomik araç iç tasarımı yapmaktır (Vogt vd., 2005). RAMSIS yazılımı hazırlanırken, insan- araç birleșiminde en önemli unsur olan konfor açıları ele alınmıştır. RAMSIS yazılımına ait kullanıcı arayüzü Şekil 1'de verilmiştir.

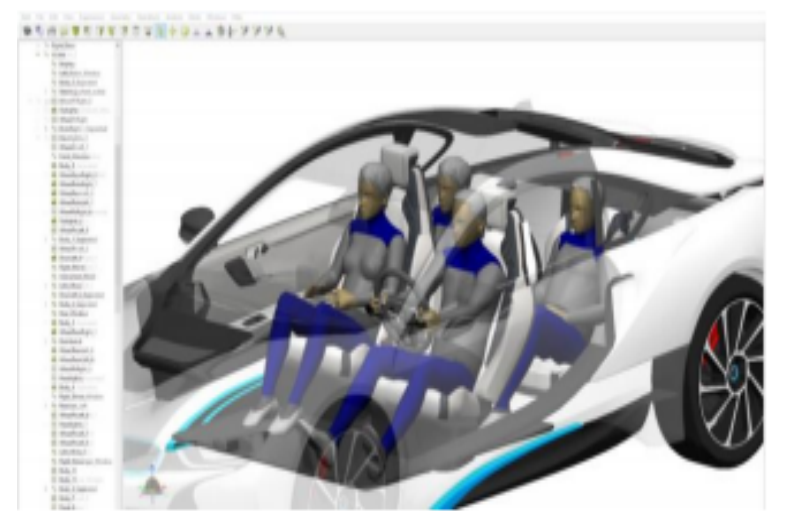

Şekil 1. RAMSIS Yazılımı Kullanıcı Arayüz Görüntüsü (Kuebler vd., 2018)

Schmidt vd., 2014 yılında otomotiv kullanıcılarının, konfor açılarının yer aldığı 30 adet makaleyi incelemiş ve derleme yapmışlardır. Yapılan derlemede çalışmaları ele alan bir tablo hazırlanmış ve 14 konfor açısı üzerinde durulmuştur (Schmidt vd., 2014).

Daha önce yapılmış olan akademik çalışmalarda RULA (Rapid Upper Limb Assessment), RAMSIS (Rechergestütztes Anthropometrisches Menschmodell zur Insassen-Simulation), OWAS (Ovako Working Postures Analysing System), CATIA V5 araştırma yöntemleri ve yazılımları kullanılarak kas iskelet sistemi incelenmiștir (Brisson vd., 1999). $\mathrm{Bu}$ çalışmada ise BTS Bio-Engineering Motion Capture görüntü yakalama tekniği kullanılarak sayısal değerler elde edilmiştir. 


\section{Yöntem}

Araștırmamız, 22-06-2018 ile 22-06-2019 tarihleri arasında, Oklahoma State Üniversitesi 19-171 sayı ve numaralı etik kurul kararına bağlı kalınarak, Stillwater kentinde bulunan Oklahoma State Üniversitesi kampüsünde yapılmıştır.

Oklahoma eyaletinde yaşayan, 30 kişilik Türk grubu içerisinden, 4 kişi rastgele seçim yöntemi ile seçilmiştir. Seçilen kişilerin boy ortalaması erkekler için, $175 \mathrm{~cm}$, kadınlar için $162 \mathrm{~cm}$, kilo ortalaması erkekler için $78 \mathrm{~kg}$, kadınlar için, $59 \mathrm{~kg}$. olarak ölçülmüştür.

Araştırmaya katılanların vücutlarında 14 farklı noktaya eklem hareketlerini ve açllarını tespit etmek için fosforlu işaretleyici küreler yapıştırılmıştır. Şekil 1. Fosforlu işaretleyici kürelerin yapıştırıldığı yerler gösterilmiştir. Şekil 2'de katılımcıların vücutlarına yapıştırılan işaretleyici kürelerin yerleri verilmiştir.

Eğitim ve İnsan Bilimleri Fakültesinde yer alan Mixed Reality laboratuvarına otomotiv simülasyonu yapmak için düzenek kurulmuştur. Kurulan düzenekte, otomatik vites kullanımı modellenmiștir. Düzenek hazırlı̆̆ı, ikinci el Ford marka bir araca ait koltuk vites ve fren-gaz takımları sökülerek ve laboratuvarda kutu profiller kullanılarak gerçek koşulları aratmayacak şekilde yapılmıștır.

Son yıllarda otomatik vitesli araçların satış rakamları yüksek olduğu için otomatik vites düzeneği tercih edilmiştir. Araştırmamızda manuel vites takımı ile çalışan bir otomotiv tercih edilmiş olsaydı sonuçlarda farklılık olabilirdi.

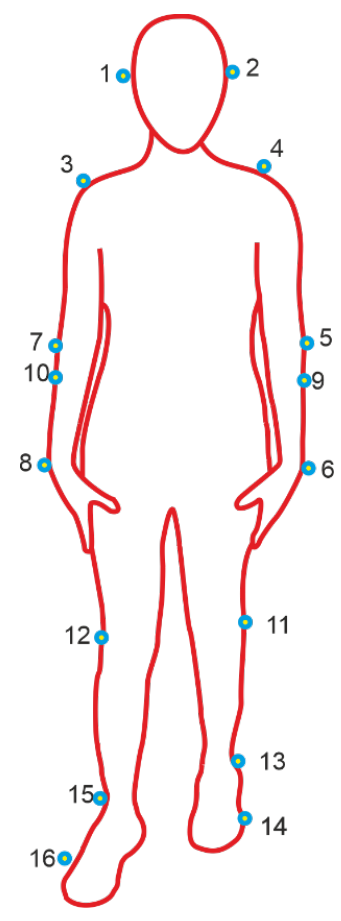

Şekil 2. Vücutta İșaretleyici Kürelerin Yapıștırıldığı Bölgeler
Deneye katılanların otomotiv sürüş esnasında aldıkları pozisyonlar modellenmiştir. Sürüş esnasında oluşabilecek pozisyonlar BTS BioEngineering yazılımı ve kamera sistemi kullanılarak görselleştirilmiştir. Çalışma yapılan "Mixed Reality" laboratuvarı ve kızlötesi kamera düzeneğine ait görsel Şekil 3'te verilmiștir.

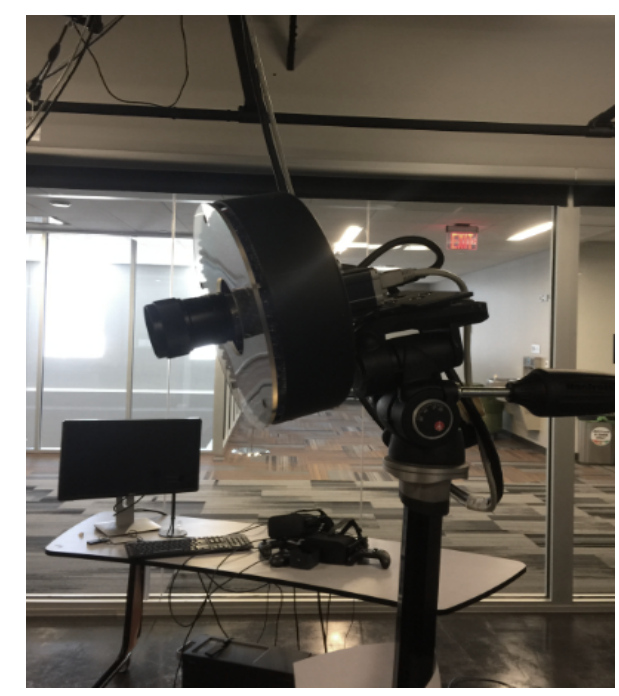

\section{Şekil 3. Mixed Reality Lab. BTS Bio-Engineering Dijital Kamera Sistemi}

Araştırma kapsamında kullanılmış olan, BTS BioEngineering Motion Capture yazilım ve donanımının teknik özellikleri incelendiğinde, çözünürlüğü 1 mega piksel ve en yüksek frekans yakalama miktarı 300 fps olan yedi adet kızılötesi dijital kamera bulunduğu görülmektedir.

Konfor açlları kamera yardımı ile kayıt altına alınmıştır. Konfor açılarına ait hesaplamalara ait denklemler aşağıda verilmiştir (1-7).

$\theta(t)=\left[\begin{array}{lllllll}\theta_{\boldsymbol{I}}(t) & \ldots & \ldots & \ldots & \theta_{j}(t) \ldots \ldots . & \left.\theta_{\boldsymbol{J}}(t)\right]^{\mathrm{T}},\end{array}\right.$

$\theta j^{*}(\theta j=1, \ldots \ldots . . . J)$, bağımsız $j$ vücut açı noktalarını ve $t$ $[0, T]$ ise zaman aralığını temsil etmektedir. Burada amaç, bağımsız hareketlerin nicel şekilde ölçülmesi ve hareketlerin görev alanlarındaki gruplara göre sınıflandırılmasıdır.

$$
\begin{aligned}
& C_{x}^{i}=\int_{0}^{T}\left(x(t)-x^{i}(t)\right) d t, \\
& C_{y}^{i}=\int_{0}^{T}\left(y(t)-y^{i}(t)\right) d t, \\
& C_{z}^{i}=\int_{0}^{T}\left(z(t)-z^{i}(t)\right) d t,
\end{aligned}
$$

Burada, $[x(t) y(t) z(t)]^{\mathrm{T}}$ ve $\left[\begin{array}{lll}x^{i}(t) & y^{i}(t) & z^{i}(t)\end{array}\right]^{\mathrm{T}}$ etki yörüngesini ifade etmektedir. $C_{x}^{i}, C_{y}^{i}$ ve $C_{z}^{i}$ eklem 
hareketindeki bağımlı yörünge dengeleyicileridir. Farklı eklem rotasyonlarındaki etkilerinin 100 'lük sistemde karşılaştırılması için 5-6 ve 7 denklemleri kullanılır (Park vd., 2005).

$$
\begin{aligned}
& P C_{x}^{i}=100 \frac{C_{x}^{i}}{\sum_{j=1}^{J}\left|C_{x}^{j}\right|}, \\
& P C_{y}^{i}=100 \frac{C_{y}^{i}}{\sum_{j=1}^{J}\left|C_{y}^{j}\right|}, \\
& P C_{z}^{i}=100 \frac{C_{z}^{i}}{\sum_{j=1}^{J}\left|C_{z}^{j}\right|} .
\end{aligned}
$$

1-Numaralı sürüş simülasyonu

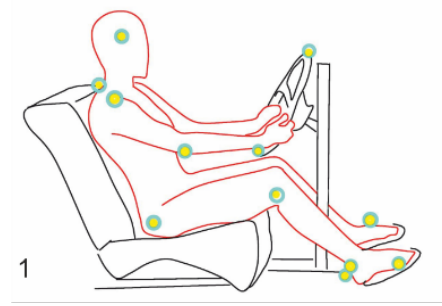

2-Numaralı sürüş simülasyonu

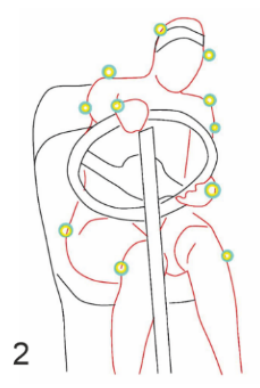

3-Numaralı sürüş simülasyonu

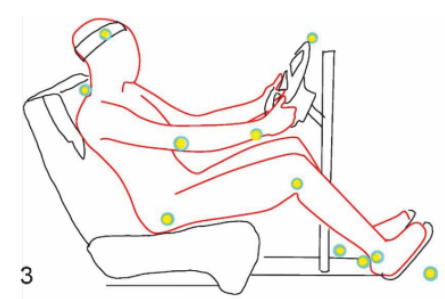

4-Numaralı sürüș simülasyonu

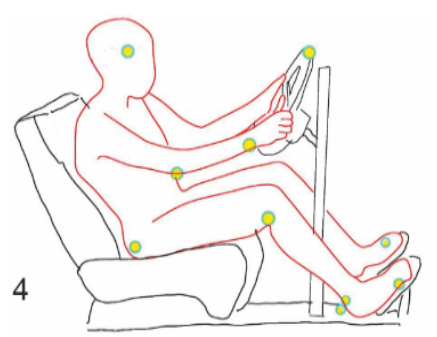

Şekil 4. Farklı Sürüş Duruşlarına Ait Görseller

Şekil 4' de görüntüleme yöntemi kullanılarak yapılmış farklı simülasyonlara ait duruşların görselleri verilmiştir. Otomotiv kullanımı esnasında sıklıkla oluşan hareketler,

1. Şerit değiştirmeden yolu takip etmek,

2. Sola doğru viraj alma pozisyonu,

3. Sağa doğru viraj alma pozisyonu,

4. Aniden șerit değiștirme durumu,

Otomotiv kullanımdaki konfor açıları, DIN 334081:2008-3 standardına bağlı kalarak oluşturulmuştur. DIN 33408 standardına ait görsel Şekil 5'te paylaşılmıştır.

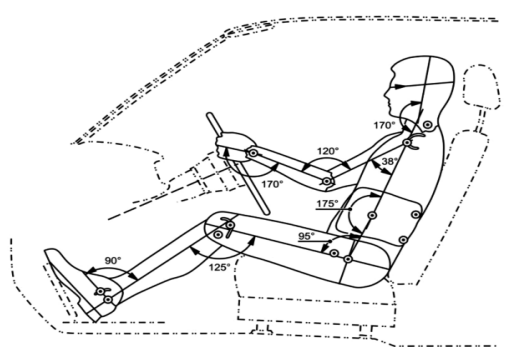

Şekil 5. DIN 33408'e konfor açıları (DIN 33408)

Otomotiv kullanıcılarının:

- Dirsek eklemi açısı,

- Omuz eklemi açısı,

- Kalça eklem açısı,

- Diz eklem açısı,

- Ayak Bileği Eklem Açısı,

İncelenmiştir ve sayısallaştırılmıştır. Ölçüm yapılan konfor açllarına ait görsel Şekil 6’da verilmiştir.

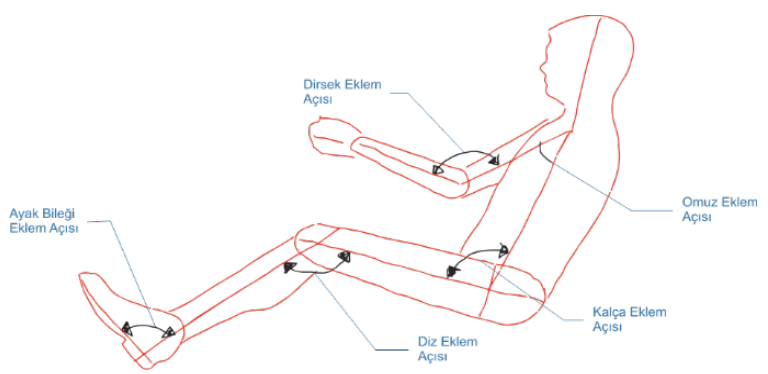

Şekil 6. Ölçüm Yapılan Konfor Açıları 


\section{Sonuçlar}

Araştırmamıza gönüllü katılan dört kişiden, ikisi kadın, ikisi erkektir. Böylelikle erkek ve kadınların otomotiv içerisindeki olası farklı duruşları analiz edilmiştir. Katılımcıların ayak bileği açısı, diz eklem açısı, kalça eklem açısı, omuz eklem açısı, dirsek eklem açlları incelenmiştir. Ölçüm yapılan konfor açıları Şekil 7'de verilmiştir.

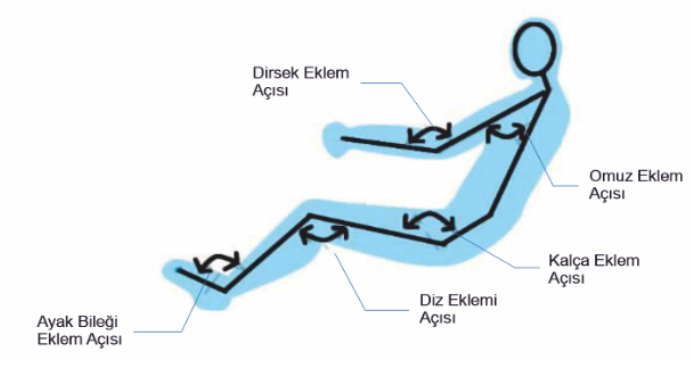

Otomotiv kullanırken oluşan vücut duruşunda sağ profilden ölçüm yapılan açılar

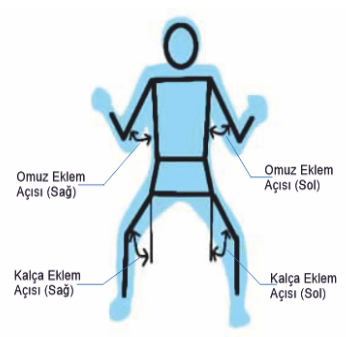

$50 \mathrm{~km}$ mesafeden daha az otomotiv Kullanılması hali

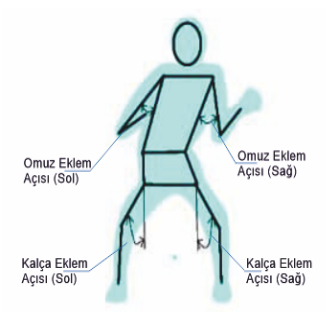

Sağa keskin dönüş yapılması hali

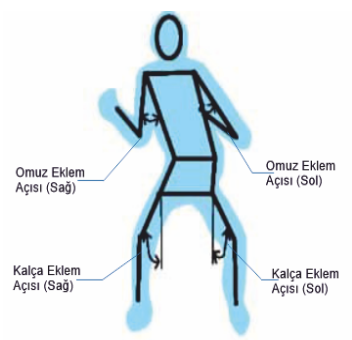

Sola keskin dönüş yapılması hali

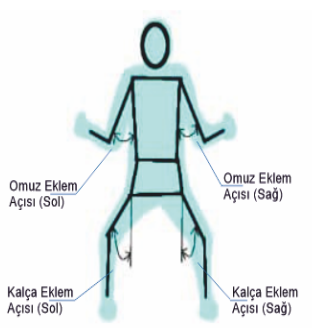

$50 \mathrm{~km}$ mesafen daha fazla otomotiv kullanılması hali

\section{Şekil 7. Hesaplanan Konfor Açıları}

SPSS paket programı kullanılarak, BTS BioEngineering yazılımı ile elde edilen verilerin normal dağılıma sahip olup olmadığına bakılmıș, verilerin Kolmogorov Simirnov ve Shapiro Wilk testlerinin sonuçlarına bakılmış, çarpıklık ve basıklık değerleri incelenmiş ayrıca varyasyon katsayısı \%16 çıkmıştır, bu değerlere göre konfor açllarının normal dağılıma sahip olduğu tespit edilmiştir.
Konfor açıları, kullanım şekline ve kullanıcıların verilerine bağlı kalınarak çift yönlü varyans analizi yapılmıştır.

Tespit edilen değerlerin gruplandırılması amacıyla Duncan çoklu aralık testi tercih yapılmıştır. Araç kullanımı esnasındaki vücut açılarının tespitinin ve analizinin yapılması için hesaplanan açılar, katılımcılar (yaş cinsiyet), sürüş modu ve sürüș duruş türleri ile ilişkili olarak tekli veya grup etkileşimi vücut açları üzerindeki etkisinine ait varyans analizi Tablo 4'te verilmiştir.

Tablo 4. Varyans Analiz Tablosu

\begin{tabular}{|c|c|c|c|c|c|}
\hline Değișkenler & $\begin{array}{c}\text { Karelerin } \\
\text { Toplamı }\end{array}$ & $\begin{array}{c}\text { Serbestlik } \\
\text { Derecesi }\end{array}$ & $\begin{array}{c}\text { Karelerin } \\
\text { Ortalaması }\end{array}$ & $\mathrm{F}$ & $\begin{array}{c}\text { Hata } \\
\text { Seviyesi }\end{array}$ \\
\hline $\begin{array}{l}\text { Eklem } \\
\text { bölgeleri }\end{array}$ & 1923371,05 & 13 & $\begin{array}{l}147951,62 \\
2\end{array}$ & $\begin{array}{l}69697,5 \\
04\end{array}$ & 0,00 \\
\hline $\begin{array}{l}\text { Sürüş } \\
\text { koşulları }\end{array}$ & 1574,647 & 3 & 524,882 & 247,263 & ,000 \\
\hline $\begin{array}{l}\text { Katılımcilar } \\
\text { (yaş- } \\
\text { cinsiyet) }\end{array}$ & 997,362 & 3 & 332,454 & 156,613 & ,000 \\
\hline $\begin{array}{l}\text { Vücut } \\
\text { açlları* } \\
\text { sürüş } \\
\text { koşulları }\end{array}$ & 11263,478 & 39 & 288,807 & 136,052 &, 000 \\
\hline $\begin{array}{l}\text { Vücut } \\
\text { açlları* } \\
\text { katılımcılar }\end{array}$ & 214,388 & 39 & 5,497 & 2,590 & ,000 \\
\hline $\begin{array}{l}\text { Sürüş } \\
\text { koşulları* } \\
\text { katılımcılar }\end{array}$ & 822,165 & 9 & 91,352 & 43,034 & ,000 \\
\hline $\begin{array}{l}\text { Vücut } \\
\text { açıları* } \\
\text { sürüş } \\
\text { koşulları* } \\
\text { katılımcılar }\end{array}$ & 489,835 & 117 & 4,187 & 1,972 & ,000 \\
\hline Hata & 1426,500 & 672 & 2,123 & & \\
\hline Toplam & 6600300,000 & 896 & & & \\
\hline $\begin{array}{l}\text { Düzeltilmiş } \\
\text { toplam }\end{array}$ & 1940159,460 & 895 & & & \\
\hline
\end{tabular}

Varyans analiz sonuçları incelendiğinde;

- Eklem bölgeleri,

- Sürüş koşulları,

- Katılımcılar (Yaş-Cinsiyet)

Tekli faktörlerin ana etkileri, ikili etkileşim grupları ve üçlü etkileşim grupları $(\mathrm{p}<0.005)$ vücut açllarında etkilidir.

Vücut açılarında etkili olan değişkenlerin aralıklarını ve gruplarının bulunması amacıyla Duncan çoklu aralık testi yapılmıştır. Tablo 5 'de otomotiv kullanımı esnasında oluşan konfor açılarının sağdan 
alınan ölçümleri ile soldan alınan ölçümlerinin farklı gruplarda olduğu gözlemlenmiștir.

\section{Tablo 5. Vücut Açıları ve Homojenlik Grupları}

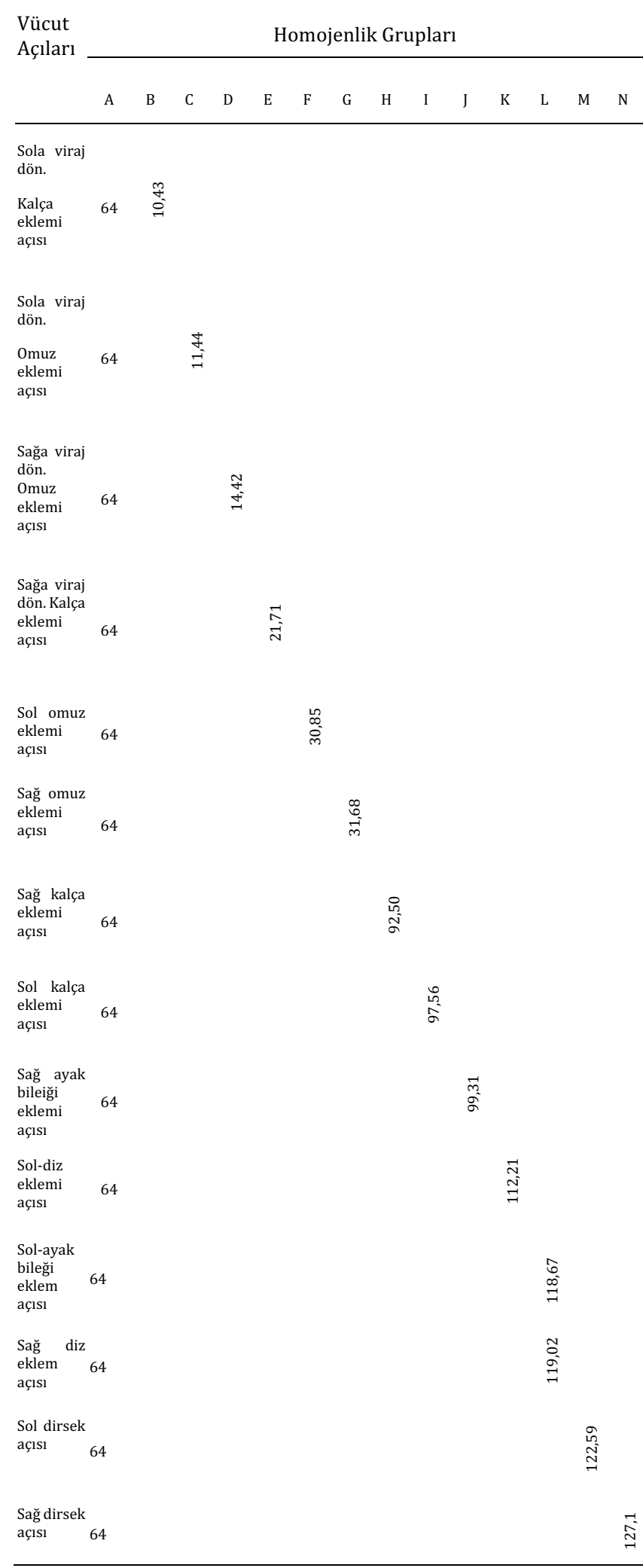

$\mathrm{Bu}$ bulgular, otomotiv kullanımı esnasında sağda vites, multimedya cihazı ve bazı sinyallerin olması, solda ise dikiz aynasının bulunmasinın oturma duruşunu etkilediğini göstermektedir. Ev ortamında herhangi bir koltukta otururken sağ ve sol açlarda bu derece farklılıklar olmamaktadır. Konfor açılarının sayısal değerleri incelendiğinde, en küçük değerin sola viraj dönüşlerinde oluşan kalça eklemi açısı $\left(10,43^{\circ}\right)$ olduğu görülmüştür. En yüksek değerde olan konfor açısı ise sağ dirsek $\left(127,1^{\circ}\right)$ açısıdır.

Tablo 6. Kullanım Şekli ve Homojenlik Grupları

\begin{tabular}{|c|c|c|c|c|c|}
\hline \multirow[b]{2}{*}{ Kullanım Șekli } & \multicolumn{5}{|c|}{ Homojenlik Grupları } \\
\hline & Adet & A & $\mathrm{B}$ & $\mathrm{C}$ & $\mathrm{D}$ \\
\hline $\begin{array}{l}\text { Sağ-viraja } \\
\text { girerek } \\
\text { manevra } \\
\text { yapmak }\end{array}$ & 224 & $70,41^{\circ}$ & & & \\
\hline $\begin{array}{l}\text { 50-km mesafen } \\
\text { kısa-araç } \\
\text { kullanmak }\end{array}$ & 224 & & $71,53^{\circ}$ & & \\
\hline $\begin{array}{l}\text { Sola-viraja } \\
\text { girerek } \\
\text { manevra } \\
\text { yapmak }\end{array}$ & 224 & & & $72,50^{\circ}$ & \\
\hline $\begin{array}{l}\text { 50-km } \\
\text { mesafeden } \\
\text { uzun-araç } \\
\text { kullanmak }\end{array}$ & 224 & & & & $74,02^{\circ}$ \\
\hline
\end{tabular}

Tablo 6'da dört farklı sürüş kullanım formunda oluşan vücut açları incelenmiştir. Duncan analizine göre sağ yönde viraja girmek ile sol yönde viraja girmek arasında istatistiksel olarak farklılık bulunmaktadır. Uzun mesafeli araç kullanımı ile kısa mesafeli araç kullanımı arasında ise istatiksel olarak fark olduğu gözlemlenmiştir.

Tablo 7. Katılımcılar ve Homojenlik Grupları

\begin{tabular}{cccccc} 
& \multicolumn{5}{c}{ Homojenlik Grupları } \\
\cline { 2 - 6 } Yaș & Adet & A & B & C & D \\
\hline Kadın $<45$ yaș & 224 & $70,38^{\circ}$ & & \\
Kadın $>45$ yaș & 224 & & $72,23^{\circ}$ & \\
Erkek $<45$ yaș & 224 & & & $72,66^{\circ}$ & \\
Erkek $>45$ yaș & 224 & & & & $73,19^{\circ}$ \\
\hline
\end{tabular}

Tablo 7'de 45 yaș altı kadın kullanıcıların vücut açıları ile 45 yaş üzeri kadın kullanıcıların vücut açları arasında fark olduğu, aynı şekilde 45 yaş altı ile 45 yaş üzeri erkek kullanıcılar arasında da fark olduğu gözlemlenmiștir. Yaş ile sürüş esnasında oluşan konfor açıları arasında farklılık olduğu görülmüștür. 
Tablo 8. Konfor Açılarının DIN, REBIFE ve RAMSIS ile karşılaștırılması

\begin{tabular}{|c|c|c|c|c|c|c|}
\hline & & $\begin{array}{l}\text { Konfor } \\
\text { Açılarının } \\
\text { Ortalaması }\end{array}$ & $\begin{array}{l}\text { Standart } \\
\text { Sapma }\end{array}$ & DIN & Rebiffe & RAMSIS \\
\hline $\begin{array}{l}\text { Ayak } \\
\text { Bileği, }\end{array}$ & 備 & $99,31^{\circ}$ & 0,816497 & $90^{\circ}$ & $90^{\circ}$ & $103^{\circ}$ \\
\hline Diz & $\begin{array}{l}200 \\
\widetilde{n} \\
\widetilde{n}\end{array}$ & $119,06^{\circ}$ & 12,11318 & $125^{\circ}$ & $95^{\circ}$ & $119^{\circ}$ \\
\hline Kalça & 每0 & $97,56^{\circ}$ & 3,68273 & $95^{\circ}$ & $95^{\circ}$ & $99^{\circ}$ \\
\hline Omuz & $\begin{array}{l}200 \\
\widetilde{N} \\
\widetilde{N}\end{array}$ & $31,69^{\circ}$ & 1,47196 & $38^{\circ}$ & $10^{\circ}$ & $22^{\circ}$ \\
\hline Dirsek & 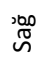 & $127,17^{\circ}$ & 1,707825 & $120^{\circ}$ & $80^{\circ}$ & $127^{\circ}$ \\
\hline $\begin{array}{l}\text { Ayak } \\
\text { Bileği }\end{array}$ & $\bar{\wp}$ & $118,67^{\circ}$ & 11,2574 & $90^{\circ}$ & $110^{\circ}$ & $103^{\circ}$ \\
\hline Diz & $\overline{0}$ & $112,22^{\circ}$ & 5,822013 & $125^{\circ}$ & $135^{\circ}$ & $119^{\circ}$ \\
\hline Kalça & $\bar{\sim}$ & $92,5^{\circ}$ & 3,937004 & $95^{\circ}$ & $120^{\circ}$ & $99^{\circ}$ \\
\hline Omuz & $\bar{i}$ & $30,86^{\circ}$ & 1,414214 & $38^{\circ}$ & $45^{\circ}$ & $22^{\circ}$ \\
\hline Dirsek & $\bar{n}$ & $122,59^{\circ}$ & 2,286737 & $120^{\circ}$ & $120^{\circ}$ & $127^{\circ}$ \\
\hline $\begin{array}{l}\text { Omuz } \\
\text { Viraj-1 }\end{array}$ & 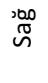 & $14,42^{\circ}$ & 0,645497 & $* * *$ & $20^{\circ}$ & $15^{\circ}$ \\
\hline $\begin{array}{l}\text { Omuz } \\
\text { Viraj-2 }\end{array}$ & $\overline{0}$ & $11,44^{\circ}$ & 0,645497 & $* * *$ & $30^{\circ}$ & $12^{\circ}$ \\
\hline $\begin{array}{l}\text { Kalça } \\
\text { Viraj-1 }\end{array}$ & 梁0 & $21,72^{\circ}$ & 2,25 & $* * *$ & $9^{\circ}$ & $24^{\circ}$ \\
\hline $\begin{array}{l}\text { Kalça } \\
\text { Viraj-2 }\end{array}$ & $\bar{i}$ & $10,44^{\circ}$ & 0,866025 & & $11^{\circ}$ & $11^{\circ}$ \\
\hline
\end{tabular}

Tablo 8'de sürüş konforunu etkileyen 14 farklı vücut açısı incelenmiş, ölçümler sonucunda elde edilen verilerin RAMSIS ve DIN standartlarına yakın değerler taşıldığı tespit edilmiştir. Otomotiv iç mekan tasarımında koltuk tasarımı önemli yere sahiptir. Veriler incelendiğinde Kadın kullanıcıların daha dar açılarda otomotiv kullandı̆̆ı, erkek kullanıcıların daha geniş açlarda otomotiv kullandıkları tespit edilmiştir. Bu durum kadın ve erkek fizyolojisinin farklı olmasıyla ilișkili olarak açıklanabilir. 50km'den daha az mesafede araç kullanımında daha geniş açı hesaplanırken, sağa keskin dönüş yapılması durumunda açlların ortalamasının daraldığı tespit edilmiştir. Eklem açıları incelendiğinde sola viraj dönüşündeki kalça eklem açısı $\left(10,43^{\circ}\right)$ en düşük değere sahipken, en geniş eklem açısının ise sağ dirsek açısı $\left(127,17^{\circ}\right)$ olduğu gözlemlenmiştir.

\section{Sonuçlar}

Hayatımızın önemli bir parçası olan otomotivlerde her geçen gün daha fazla vakit geçirmekteyiz. Büyük şehirlerde sıkışık trafikte dur kalk yaparak bir noktadan bir noktaya ulaşmak bazen saatler sürmekte, bu durum, yanlış vücut duruşları yüzünden otomotiv kullanıcılarının kas ve iskelet sistemlerinde oluşan risk altına sokmaktadır. Pek çok bilim adamı otomotiv iç mekanı ve konforu hakkında araştırma yapmış sonuç olarak eklemlerde oluşan konfor açılarının belirli sınırlar çerçevesinde olması gerektiğini belirtmişlerdir.

Otomotiv ergonomisi için yapılan çalışmaları üç farklı temel alanda görmekteyiz. Bu üç farklı temel alanın içinde otomotiv ergonomisi için hazırlanmış yazılımlar, REBA ve RULA analizleri ve görüntüleme teknolojisidir. Bizim çalışmamızda, laboratuvar ortamında otomotiv koltuğu, direksiyon ve pedal takımları 1/1 ölçekli otomotiv modeli kullanılmış, cinsiyet ve yaş farkına bağlı değişebilen konfor açıları incelenmiş. Kadın ve erkek sürücüler arasında sürüş konforu açısından büyük ölçüde fark olduğu gözlemlenmiştir. Kadınların erkeklerden daha dar açılar ile araç kullandığı, uzun mesafe sürüşlerde konfor açılarının genişlediği kısa mesafede daraldığı gözlemlenmiştir. Otomotiv kullanıcıları için ilerleyen senelerde firmaların uzun yol ve şehir içi kullanımı için koltuk, direksiyon ve pedallarda, farklı ölçüler ve sertlikler sunması önerilmektedir. Gelecek çalıșmalarda, farklı araç sınıfları içinden uygun koltuk modelinin araştırılması planlanmaktadır.

\section{Tartışma}

Günlük otomotiv kullanımında, kas ve iskelet sistemimizin risk altında olup olmadığını anlamak için yapılmış olan bu çalışmada cinsiyet ve yaş farklarına göre konfor açıları incelenmiştir. Otomotiv kullanıcılarının konfor açlları 1945'lerden sonra merak konusu olmuş hem otomotiv imalatı yapan firmalar hem de bilim adamları konuyu detaylı olarak araştırmışlar, hatta otomotiv kullanımını daha rahat ve fonksiyonel hale getirmek için yeni buluşlara imza atmışlardır. Eldem ve arkadaşları (2019) yapmış oldukları çalışmada, otomotiv kullanıcılarında CATIA V5 programı kullanarak insan otomotiv modellemesi yapmışlar, REBA ve RULA analiz yöntemleri kullanarak otomobil sürücülerinde kas iskelet sisteminde oluşan risk analizlerini yapmışlardır. Yapılan ergonomik değerlendirmelere göre; sürücü koltuğu ve gaz pedalı arasındaki mesafelerin yeniden tasarlanması, sürücü koltuklarının sırt eğimlerinin düzenlemesi ve 
sol ayak için özel bir ayak koyma yeri planlanması şeklinde olmuştur. Naddeo ve Memoli (2009) yapmış oldukları çalışmada FIAT otomotiv firmasının geliştirmiş olduğu "Manikin" yazılımını kullanarak dijital insan modelleri oluşturmuşlar oluşturdukları modellere REBA analizi yapmışlardır, "Manikin' yazılımı ile elde edilen konfor açılarının en sağlıklı çözüm olduğunu iddia etmişlerdir. Yapılan çalışmalar incelendiğinde iki boyutlu veya üç boyutlu modellerin farklı sonuçlar verdiği, ülkeden ülkeye farklı sonuçlar alındığı hatta koltuktan koltuğu bile farklı konfor açların oluştuğu gözlemlenmiștir.

\section{Teşekkür}

Çalışmamızın görüntüleme yöntemi analizi kısmının yapılması aşamasında, Oklahoma State Universitesi OSU- Mixed Reality Laboratuvarını kullanma imkanı sundukları için İnsan Bilimleri Fakültesi yönetimine teşekkür ederiz.

\section{Çıkar Çatışması}

Yazarlar tarafından herhangi bir çıkar çatışması beyan edilmemiştir.

\section{Kaynaklar}

Andreoni, G., Rabuffetti, M., Pedotti, A., Quattrocolo, S., Cerrone, M., \& Tarzia, A. (1999). Accessibility Simulation and Ergonomic Evaluation for Virtual Prototyping (No. 1999-01-1925). SAE Technical Paper.

Carayon, P., Smith, M. J. (2000). Work organization and ergonomics. Applied ergonomics, 31(6), 649662 .

Chaffin, D.B. \& Andersson. G.B., (1991). Occupational Biomechanics. $2^{\text {nd }}$ ed. Wiley, New York, USA.

DIN 33408-1:2008-03, Körperumrissschablonen Teil 1: Für Sitzplätze

Eldem, C., Neslihan, T. O. P., Şahin, H. (2019). Dijital insan modelleri kullanarak otomobil sürücüsü duruş pozisyonlarının ergonomik değerlendirilmesi üzerine bir çalıșma. Gazi Mühendislik Bilimleri Dergisi (GMBD), 5(1), 22-31.

Graf, M., Guggenbühl, U., Krueger, H. (1995). An assessment of seated activity and postures at five workplaces. International Journal of Industrial Ergonomics, 15(2), 81-90.
Grieco, A. (1998). Application of the concise exposure index (OCRA) to tasks involving repetitive movements of the upper limbs in a variety of manufacturing industries: preliminary validations. Ergonomics, 41(9), 1347-1356.

Gowtham, S., Ramnaath, M., Sudharsan, S., Kumar, B. L., Praneeth, V., Dinesh, S., Subramaniyam, M. (2020, August). Seating comfort analysis: a virtual ergonomics study of bus drivers in private transportation. 3rd International Conference on Advances in Mechanical Engineering (ICAME 2020) (Vol. 912, No. 2, p. 022018). IOP Publishing. doi:10.1088/1757-899X/912/2/022018

Guenaelle, P. (1995, March). One methodology to evaluate automotive seat comfort. In Proceedings of the Third International Conference on Vehicle Comfort and Ergonomics, Bologna, Italy (pp. 2931).

Gyi, D. E., Porter, J. M., Robertson, N. K. (1998). Seat pressure measurement technologies: considerations for their evaluation. Applied Ergonomics, 29(2), 85-91.

Huang, Y. H., Robertson, M. M. Chang, K. I., (2004). The role of environmental control on environmental satisfaction, communication, and psychological stress: effects of office ergonomics training. Environment and Behavior, 36(5), 617637.

Kamp, I. (2012). The influence of car-seat design on its character experience. Applied ergonomics, 43(2), 329-335.

Kaya, Ö., Akalp, G. (2017). İş sağlığı ve güvenliği açısından elle taşıma işlerinin değerlendirilmesi (tekstil ve otomotiv sektörü örneği). Is, Güc: Endüstri Iliskileri ve Insan Kaynaklari Dergisi, 19(2), 79-90.

Kaya, Ö., Özok, A. F. (2017). Tasarımda antropometrinin önemi. Mühendislik Bilimleri ve Tasarım Dergisi, 5, 309-316.

Kuebler, T., Wirsching, H., Barnes, D. (2018). RamsisDigital Human Modeling for Optimized Safety and Survivability of the Warfighter.

Latko, W. A., Armstrong, T. J., Franzblau, A., Ulin, S. S., Werner, R. A. Albers, J. W., (1999). CrossSectional Study of The Relationship Between 
Repetitive Work and The Prevalence of Upper Limb Musculoskeletal Disorders. American Journal of İndustrial Medicine, 36(2), 248-259.

Lay, W. E., \& Fisher, L. C. (1940). Riding comfort and cushions (No. 400171). SAE Technical Paper.

Mah, C.D., Hulliger, M., Lee, R.G. O'Callaghan, I., (1994). Quantitative Analysis Of Human Movement Synergies: Constructive Pattern Analysis for Gait. Journal of Motor Behavior, 26, 83-102.

Naddeo, A., Cappetti, N., Vallone, M., Califano, R. (2014). New trend line of research about comfort evaluation: proposal of a framework for weighing and evaluating contributes coming from cognitive, postural and physiologic comfort perceptions. In Advances in Social and Organizational Factors, Edited by Peter Vink, Published By "Advances in Human Factors and Ergonomics" Conference.

Park, W., Martin, B. J., Choe, S., Chaffin, D. B. Reed, M. P. (2005). Representing and Identifying Alternative Movement Techniques for GoalDirected Manual Tasks. Journal of Biomechanics, 38(3), 519-527.

Schmidt, S., Amereller, M., Franz, M., Kaiser, R., Schwirtz, A. (2014). A literature review on optimum and preferred joint angles in automotive sitting posture. Applied ergonomics, 45(2), 247-260.

Seidl, A. (1997). RAMSIS-A new CAD-tool for ergonomic analysis of vehicles developed for the German automotive industry (No. 970088). SAE Technical Paper.

Straker, L. \& Mekhora, K. (2000). An Evaluation of Visual Display Unit Placement by Electromyography, Posture, Discomfort and Preference. International Journal of Industrial Ergonomics, 26(3), 389-398.

Ulker O. (2020). Koltuk İmalatındaki Zorlanmaların BAUA Yöntemi ile Değerlendirilmesi, Ergonomi, $3(1), 45-54$.

Vogt, C., Mergl, C., Bubb, H. (2005). Interior layout design of passenger vehicles with RAMSIS. Human Factors and Ergonomics in
Manufacturing \& Service Industries, 15(2), 197212.

Zhang, X., \& Chaffin, D. B. (1996, October). Task effects on three-dimensional dynamic postures during seated reaching movements: an analysis method and illustration. In Proceedings of the Human Factors and Ergonomics Society Annual Meeting (Vol. 40, No. 13, pp. 594-598). Sage CA: Los Angeles, CA: SAGE Publications.

Zhang, X., Nussbaum, M. A. Chaffin, D. B. (2000). Back Lift Versus Leg Lift: an Index and Visualization of Dynamic Lifting Strategies. Journal of Biomechanics, 33(6), 777-782.

Zhou, B., Chen, L., Tian, J., Peng, Z. (2017, June). Learning-based seat belt detection in image using salient gradient. In 2017 12th IEEE Conference on Industrial Electronics and Applications (ICIEA) (pp. 547-550). IEEE. 


\title{
KORONAVİRÜS KAPANMA (KISITLAMA) DÖNEMİNDE ÜNIVERSİTE ÖĞRENCÍLERİNINN YORGUNLUK DÜZEYİ VE KAS-İSKELET SISTEMİ RAHATSIZLIKLARI ARASINDAKİ İLIŞKİNIN BAZI DEĞİŞKENLER AÇISINDAN İNCELENMESI
}

\author{
Derya İDE ${ }^{*}$, Tülin GÜNDÜZ² \\ ${ }^{1}$ Bursa Teknik Üniversitesi, Rektörlük, Ortak Dersler Bölümü \\ ORCID No: http://orcid.org/0000-0002-6004-7201 \\ 2 Bursa Uludağ Üniversitesi, Mühendislik Fakültesi, Endüstri Mühendisliği Bölümü \\ ORCID No: http://orcid.org/0000-0002-7134-3997
}

\author{
Anahtar Kelimeler \\ Covid-19 \\ Ergonomi \\ Bireysel güç \\ kontrol listesi(CIS) \\ Kas iskelet sistemi \\ rahatsızlıkları(KISR) \\ Cornell (CMDQ) \\ Biyolojik ritim
}

\begin{abstract}
Öz
Covid-19 salgını birçok faaliyeti olumsuz etkilemiștir ve eğitim süreçleri bunların başında gelmektedir. Bu süreçlerde, uzaktan eğitim sistemlerinin yüz yüze eğitim modellerinin yerini alması ile doğru eğitim ortamını oluşturma ve hem fiziksel hem de zihinsel sağ̆lğı koruma çabası ögrrenciye bağımlı hale gelmiştir. Bu çalışmada, pandemi döneminde eğitim faaliyetlerine çevrimiçi devam eden üniversite öğrencilerinin yorgunluk düzeyleri ve kas-iskelet sistemi rahatsızlıklarının incelenmesi amaçlanmış̧ır. Analiz için anket tasarlanmıștır ve Türkiye'de bulunan 154 üniversite öğrencisine uygulanmıștır. Yorgunluk düzeyi için Bireysel Güç Kontrol Listesi (CIS), kas iskelet sistemi zorlanmaları için Cornell Kas-İskelet Rahatsızlıkları Anketi (CMDQ) kullanılmıștır. Öğrencilerin \%85,1 'i kendini yorgun hissetmektedir. Toplam yorgunluk ile cinsiyet, hissedilen yorgunluk, oturma şekli ve uyku düzeni bozukluğu ilişkileri analiz edildiğinde anlamlı farklar bulunmuștur ( $p \leq 0.05)$. Kadınlarda, erkeklerden daha yüksek yorgunluk düzeyi görülmüștür. Cornell sonuçları değerlendirildiğinde, vücut bölümlerinin rahatsızlı puanlarl; bel $(\% 18,26)$, sirt $(\% 17,02)$, boyun $(\% 16,81)$ ve omuz $(\% 11,54)$ olarak bulunmuștur. Bu bölgelerdeki kas-iskelet sistemi rahatsızlı puanları cinsiyete göre incelendiğinde, kadınlar erkeklere göre daha yüksek zorlanma yașamaktadır(p $\leq 0.05)$. Yorgunluk ve Cornell puanları arasındaki korelasyon değeri 0,416 olup aralarında pozitif yönlü ve anlaml $(p \leq 0.01)$ bir ilișkiye sahip oldukları tespit edilmiștir. Öğrencilerin günlük biyolojik ritimlerini dikkate alarak değerlendirme yapabilmek için ders izleme ve çalış̧ma süresi, 06.00-19.00(gündüz) ve 19.00-06.00(gece) olarak 2'ye bölünmüștür. Katılımcıların yarısı gece saatlerinde aktif olarak çalışmaktadır. Saat aralıklarına dair Cornell puanları hesaplanmıștır. Gece çalıșmalarında olușan omuz risk puanı gündüze göre anlamlı düzeyde farklıdır $(p=0,038)$. Pandemi döneminde ögrencilerin biyolojik ritimlerinin bozulmasl, gelecekte karșllașabilecekleri çeșitli hastallk risklerini büyük ölçüde arttırma potansiyeline sahip olabilecektir.
\end{abstract}

\section{INVESTIGATION OF RELATIONSHIP BETWEEN UNIVERSITY STUDENTS' FATIGUE LEVEL AND MUSCULOSKELETAL DISORDERS IN TERMS OF SOME VARIABLES DURING THE CORONAVIRUS SHUTDOWN (RESTRICTION) PERIOD}

\author{
Keywords \\ Covid-19 \\ Ergonomics \\ Checklist Individual \\ Strength (CIS) \\ Musculoskeletal \\ Disorders (MSDs) \\ Cornell (CMDQ) \\ Biological rhythm
}

\begin{abstract}
Covid-19 pandemic has negatively affected many activities and educational processes are at the top of them. With the replacement of face-to-face education models with distance education systems in the processes, the effort to create the right education environment and to protect both physical and mental health has become dependent on the student. In this study, it was aimed to examine the fatigue levels and musculoskeletal disorders of university students who continue their educational activities online during the pandemic period. A questionnaire was designed and applied to 154 university students in Turkey. Checklist Individual Strength(CIS) were used for fatigue level and Cornell Musculoskeletal Discomfort Questionnarie (CMDQ) were used for musculoskeletal strains. 85.1\% of the students feel tired. The relationships between total fatigue and gender, perceived fatigue, sitting style and sleep disorder were analyzed and significant differences were found $(p \leq 0.05)$. Women had a higher level of fatigue than men. Cornell results are evaluated as follows; waist $(18,26 \%)$, back $(17,02 \%)$, neck $(16,81 \%)$ and shoulder $(11.54 \%)$. The musculoskeletal disorders scores in these regions were examined by gender, it was observed that women experienced higher strain than men ( $p \leq 0.05)$. In order to be able to evaluate students' biological rhythms, the lesson monitoring and study time is divided into 2 as 06.00-19.00 (day) and 19.00-06.00 (night). Half of the participants work actively at night. Cornell scores for hour intervals were calculated. Shoulder risk score in night work is significantly different compared to daytime $(p=0,038)$. The correlation value between fatigue and Cornell score is 0.416 and it has been determined that they have a positive and significant $(p \leq 0.01)$ relationship between them. Disruption of the biological rhythms of students during the pandemic period may have the potential to greatly increase the risk of various diseases they may encounter in the future.
\end{abstract}

Araștırma Makalesi

Başvuru Tarihi

Kabul Tarihi

$: 10.05 .2021$
$: 19.07 .2021$

Research Article

Submission Date Accepted Date
: 10.05 .2021

: 19.07 .2021

\footnotetext{
* Sorumlu yazar e-posta: derya.ide@btu.edu.tr
} 


\section{Giriş}

Çin'in Wuhan kentinde, 2019 yılı Aralık ayında, yeni tip koronavirüs (2019-nCoV, veya COVID-19) adı verilen yeni bir koronavirüs türü tespit edilmiş; hızla tüm Çin'e ve dünyaya yayılmıştır (Zhu vd., 2020) Covid-19 'un dünya çapında hızla yayılması, Dünya Sağllk Örgütü'nün (WHO) 11 Mart 2020 'de bunu "pandemi" olarak duyurmuştur (WHO Timeline COVID-19, 2020). Bu dönemin olumsuz etkilerini azaltmaya yönelik, ekonomi, sağlık, eğitim gibi alanlarda farklı uygulamalar devreye alınmıştır. Dünyada pek çok hükümet, sosyal teması sinırlandıran tedbirler getirerek koronavirüsün yayılmasını azaltma ortak hedefini takip etmişlerdir(Gonzalez vd.,2020).

Covid-19 pandemisinde kısıtlamalar ve karantina nedeniyle çok sayıda kişi evde hareketsiz kalmıştır. Kişiler, ergonomik olmayan ve alışılmadık bir ortamda, yoğun çalışma programlarına devam etmek zorunda kaldıkları için kas-iskelet sistemi sorunları ortaya çıkmıştır(Kayabinar vd., 2021). Bu süreç, milyonlarca kişiyi evden, bilgisayar ve cep telefonlarını derme çatma iş istasyonlarında, genellikle mutfak masalarında veya kanepelerde çalışmaya zorlamıştır. Uzaktan çalışma, kişileri Covid-19' a karşı korumaya yardımcı olabilirken, aynı zamanda beklenmedik sonuçlara da yol açmaktadır ( Covid-19 \& Ergonomics: Wait, What?., 2020).

Covid-19 pandemisi döneminde kapalı alanlarda toplanma en aza indirilmelidir, bu da siniflardaki öğrenci sayısının azaltılması gerektiği anlamına gelmektedir(Soltaninejad vd., 2021). Eğitim sektörü Covid-19 ile mücadelenin çok önemli bir parçasıdır. Pandemi, her seviyedeki eğitim kurumunu kapılarını kapatmaya zorlamıştır(Şekil 1). Bu kurumların kapatılması, eğitim üzerinde benzeri görülmemiş bir etkiye sahiptir (Kapasia vd., 2020).

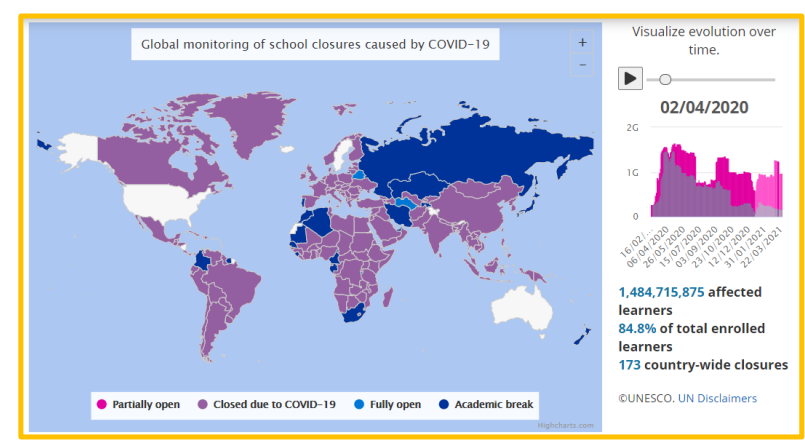

Şekil 1. Covid-19 Nedeni İle Okul Kapanışlarının En Yüksek Küresel Etki Oranı (Global monitoring of school closures, 2020)

Covid-19'un ülkelerin eğitim sistemleri üzerindeki etkisi açısından birçok farklılık mevcuttur (Gonzalez vd., 2020). Yükseköğretim kurumlarında çevrimiçi öğrenme genellikle kayıtlı dersler ve çevrimiçi platformlar aracılığıyla gerçekleşirken; bazı üniversiteler hem öğrenciler hem de öğretmenler için bilgi teknolojisi (BT) altyapısının olmaması nedeniyle öğrenmeyi ve öğretmeyi bir sonraki duyuruya kadar ertelemiștir (Policy Brief: Education during COVID-19 and beyond, 2020). Eğitimde ülkelerin ortak uygulaması ise yüz yüze eğitimin yerini büyük ölçüde uzaktan eğitim sistemlerinin alması olmuştur. Eğitim faaliyetlerine devam edebilmek için uzaktan çalışma modeli, okulların devreye aldığı bir çözüm sunmuștur. Eğitimsel bilgilendirmenin önemli bir parçası olan çevrimiçi eğitim, uzaktan eğitimden doğmuştur(Song vd., 2018). Bu eğitim türü, pandemi nedeniyle dünya genelinde meydana gelen akademik krizleri çözmenin tek yoludur (Alam, basım aşamasında). Eğitim faaliyetlerinin aksatılmaması için çevrimiçi eğitim etkili bir çözüm olmasına rağmen öğrenme araçlarında geçirilen sürenin artması, eğitime devam edilen alanlar, kișilerin pozisyonları aynı zamanda kișiler üzerinde ergonomik yüklerin olușmasına sebep olmaktadır. Ülkeler, eğitimde dijital yöntemler ve ortamlarda süreçlerin aksamaması için çaba göstermiştir bununla birlikte çok sayıda üniversite öğrencisi eğitim sisteminde bu değişikliklere hızla adapte olmaya çalışmıştır. Keskin vd.(2020) pandemi sürecinde çevrimiçi eğitim alan üniversite öğrencilerinin acil yapılandırılmış web tabanlı eğitim hakkındaki geri bildirimlerini değerlendirmiştir. Öğrencilerin \%84.4'ü web tabanlı çevrimiçi eğitimin, yüz yüze eğitim kadar etkili olmadığını, \%45.7'si bunun yüz yüze eğitime alternatif olduğunu belirtmiştir. Agormedah vd.(2020) üniversite öğrencilerinin uzaktan eğitime tepkilerini değerlendirmek için yaptığı çalışmada, öğrencilerin çevrimiçi eğitime olumlu yaklaştığını göstermiştir. Gonzalez vd.(2020) üniversite öğrencilerini yüz yüze eğitimleri kesintiye uğrayan (pandemi dönemi) ve uğramayan (pandemi öncesi) öğrenciler olarak gruplandırarak yaptıkları çalışmada, Covid-19 kısıtlamalarının öğrencilerin öğrenme stratejilerini daha sürekli bir alışkanlığa dönüştürdüğü ve verimliliklerini artırdı̆̆l sonucu elde etmiștir. Bu sonuçlar her ne kadar bu eğitim modelinin yaklaşım ve alışkanlık olarak pozitif yönde ilerleme kaydettiğini gösterse de öğrencilerin fiziksel ve mental yönden iyilik hallerinin Covid-19 ile birlikte negatif etkilendiği gerçeğini değiştirmemektedir.

Covid-19 'un eğitim-öğretim faaliyetlerine etkisi ile öğrenciler için ev, işyeri, ulaşım araçları gibi farklı çevreler eğitim ortamı haline gelmiştir. Bu dönemde, mobil cihazlar ve bilgisayarlar gibi öğrencilerin sahip olduğu eğitim araçları kişiden kişiye farklılık göstermiş; bireye bağlı öğrenme ortam ve araçları ile eğitim faaliyetlerinin sürdürülmesi gerekmiştir (Şekil 2). Realyvásquez-Vargas vd. (2020) Covid-19 
salgını sırasında çevrimiçi eğitim alan üniversite öğrencilerinin akademik performansına çevresel faktörlerin etkisini incelemişlerdir. Sonuçlar, sıcaklık, aydınlatma ve gürültünün üniversite öğrencilerinin akademik performansı üzerinde önemli doğrudan etkileri olduğunu göstermiştir.

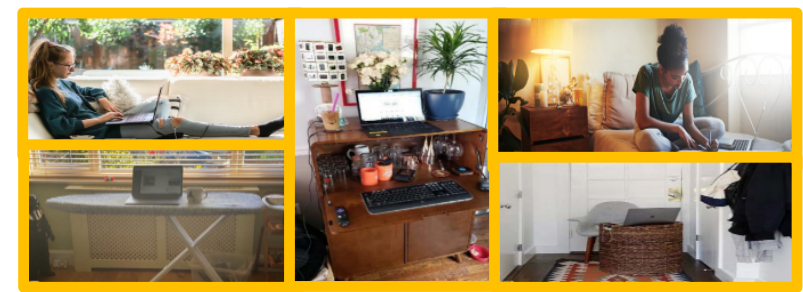

Şekil 2. Uzaktan Eğitimde Farklı Çalışma Alanları (Schulze, 2020)

Çevrimiçi dersler için dizüstü bilgisayarların veya cep telefonlarının önünde uzun saatler boyunca oturmak zorunda kalan öğrenciler, genellikle yatakta, kanepede veya yemek masasında kötü postür sergilerler, bu da performanslarını etkileyebilecek sırt, omuz ve boyun ağrısı gibi sağlık sorunlarına yol açmaktadır. Yanlış postür ve hareket eksikliği zarar verebilmektedir ve artan stres seviyelerine sebep olarak öğrencilerin odaklanmasını zorlaştırmaktadır (Ergonomic home study station for students, 2020).

Bu yeni dönem ile birlikte boyun, sirt ve omuzlarda ağrı ve rahatsızlık yaşayan insan sayısında ani bir artış beklenmektedir ve bu ağrılar uzun dönemli kasiskelet sistemi rahatsılıklarına (KISR) dönüşebilir(Ergonomics Tips for Working at Home | School of Education, 2021). 2020 yılı dünya nüfusu yaklaşık 7.8 milyar kişidir (World Population Data, 2020). Genel nüfus içerisinde önemli bir yer tutan üniversite öğrencilerinin yaklaşık \%19,23'ü Covid19'un eğitime yansımasından etkilenmiştir. Bu etki, büyük bir öğrenci kitlesinin KİSR ve benzeri sağlık sorunları yaşamaya yatkın olduğu gerçeğini gözler önüne sermektedir. Bu risklerin değerlendirilmesi gereklidir. İnsanı gözlemleyip, olumsuz koşul görüldüğü takdirde çevreye müdahale ederek, optimal koşulları oluşturmak için ergonomi, birçok farklı analiz ve yöntem sunmaktadır(Ide vd., 2018). Çalışan özbildirimleri, gözlemsel yöntemler ve direkt ölçüm yöntemleri olarak sınıflandırılan analizlerle ergonomik riskler değerlendirilebilmektedir (Tablo1).

Covid-19 sürecinde takip edilmesi gereken dersler (senkron-asenkron), sinavlar, ödevler, akademik çalışmalarda çevrimiçi öğrenme araçlarını kullanan öğrenciler için değerlendirilmesi gereken bir diğer konu ise günlük biyolojik ritimlerinde oluşan değişiklikler ve bunların etkileridir.
Tablo 1. Ergonomik Risk Analiz Yöntemlerine Örnekler

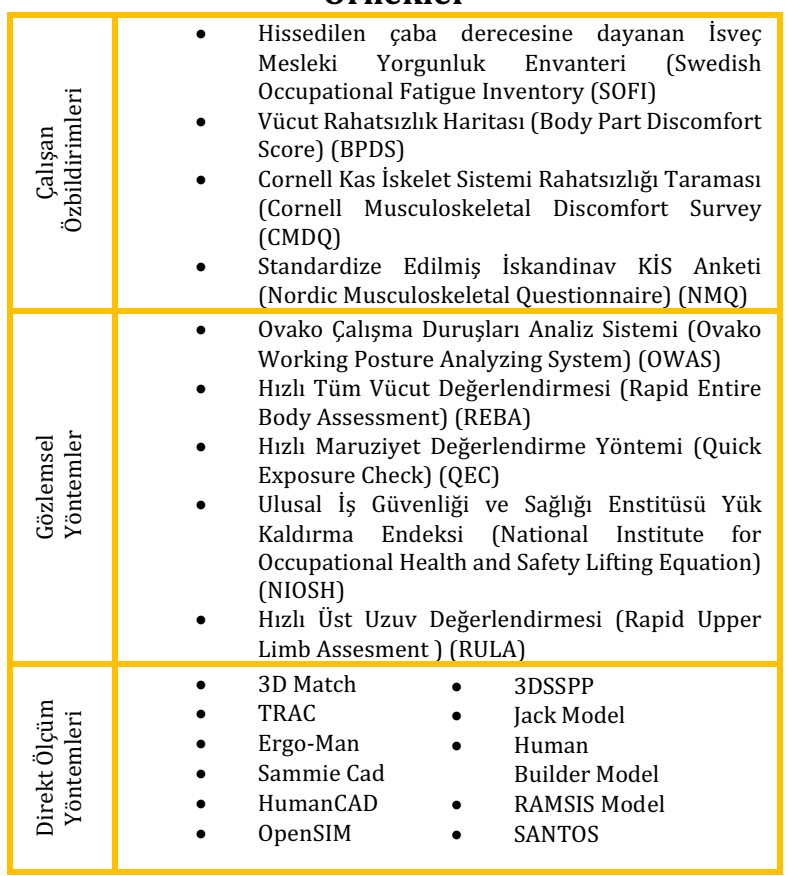

Pandemi, beden saatlerinin düzenli biyolojik ritimlerini, pandemi öncesi duruma göre yeniden oluşturmasını güçleştirmektedir. Bu güçlük, Covid19 döneminde uyku düzeninin bozulmasına da bir etkendir öyle ki bazı uzmanlar pandemi dönemindeki uyku bozukluklarını tanımlamak için "Coronasomnia' veya 'Covid-somnia" terimini kullanmıș ve bunun yeni bir hastalık türü olduğunu belirtmişlerdir(The 'coronasomnia' phenomenon keeping you from getting sleep - BBC Worklife, 2021). Biyolojik saatin 24 saatlik gece-gündüz ve aydınlık-karanlık döngüsünün uygun şekilde düzenlenmesinin hem zihinsel, hem de bedensel iyi olma durumunu sağlamada önemli bir bileșen olduğu anlaşılmaktadır (Güzel Özdemir ve Işık, 2020).

Uyku düzeninin bozulması, yetersiz ve dengesiz beslenme, günlük yaşamda aktivite ve hareketin az olması, çalışma yaşamı ve kişisel sorumlulukların geçici olarak artması yorgunluğa neden olabilmektedir(Ergin, 2009). Covid-19 ile birlikte kişiler, bu faktörlerden bir ya da birkaçı ile farklı boyutlarda karşı karşıya kalmıştır. Sağlıklı uyku, Covid-19 salgını gibi büyük yaşamsal olaylarla, fiziksel ve psikolojik olarak baş etmede kritik bir rol oynar (Morin vd., 2020).

Wathelet vd.(2020) Covid-19 karantinasındaki üniversite öğrencilerinin mental sağlık sorunları ile ilgili intihar düşüncesi, şiddetli sıkıntı, yüksek düzeyde algılanan stres, şiddetli depresyon ve yüksek düzeyde anksiyete yaygınlığı faktörlerini incelemişlerdir. Kısıtlamaların zihinsel sağlık sonuçlarına odaklanan çalıșmaların yanında 
yorgunluğun oluşumunu nasıl etkilediğini değerlendiren çalışmalarda yapılmıştır. Üniversite öğrencileri için yorgunluk değerlendirmesinin yapılması da ayrıca önem taşımaktadır. Yükseköğretim kurumlarının uzaktan eğitime ilișkin yaptıkları usul ve esas değişiklikleri de göz önüne alındığında, yeni düzenlemeler ile uzaktan eğitimin yalnız pandemi sürecinde değil gelecekte de eğitim sistemimizde büyük etkiye sahip olacağı aşikardır. Öğrenci sayılarının her yıl artış göstermesi ve ilerleyen yıllarda bu artışın devam edeceği tahminleri, bu etkinin daha geniş bir perspektifte incelenmesi gerektiğini gözler önüne sermektedir (Şekil 3).

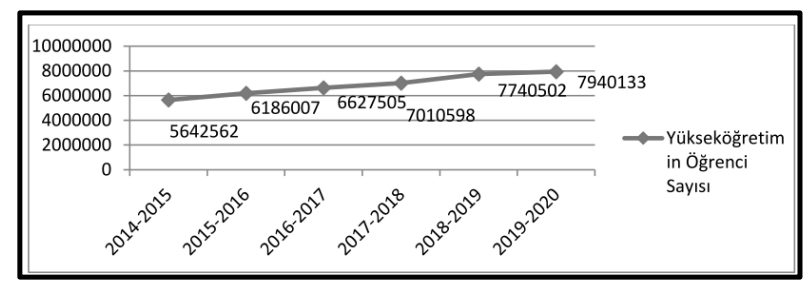

Şekil 3. Üniversitelerde Öğrenim Gören öğrenci Sayılarının Yıllara Göre Dağılımı(Eroğlu ve Kalaycı, 2020)

Yapılan bu çalışmanın amacı, pandemi döneminde çevrimiçi eğitim alan üniversite öğrencilerinin yorgunluk seviyeleri, biyolojik ritim ve ergonomik risklerinin değerlendirilmesidir. Yapılan literatür analizine göre; yorgunluk, biyolojik ritim ve ergonomik risklerin birlikte değerlendirildiği bir çalışma bulunmamaktadır. Üniversite öğrencilerinin, fiziksel ve mental sağlıklarının sürdürülmesi ancak değerlendirilen bu risklerin azaltılması ile mümkün olacaktır.

\section{Yöntem}

Çalışmaya Covid-19 ile mücadele döneminde çevrimiçi öğrenim gören üniversite öğrencileri dahil edilmiştir. Çalışma için üniversitenin "Fen, Mühendislik ve Sosyal Bilimleri Araştırmaları Etik Kurulu"nun 7 Mayıs 2021 tarih ve 5 nolu kararı ile araştırmanın etik ve bilimsel açıdan uygunluğu onaylanmıştır. Analiz için anket tasarlanmış ve üniversite öğrencilerine çevrimiçi olarak uygulanmıştır (Şekil 4).

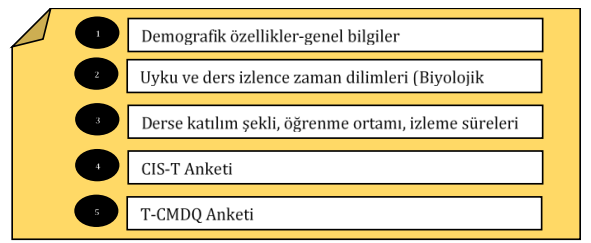

Şekil 4. Anket Bölümleri

\subsection{Cornell Kas İskelet Sistemi Rahatsızlık Anketi}

Ergonomik riskleri incelemek için yöntem seçilirken, değerlendirilecek işin düzeyi, tekniği kullanacak kişinin bilgi düzeyi gibi faktörler göz önüne alınmaktadır. Yapılan bu çalışmada uzaktan uygulanabilirlik, vücut bölgelerinin katılımcılar tarafından kolay anlaşılabilmesi, yüz yüze değerlendirme ihtiyacı olmayan yöntem olması ergonomik değerlendirme yöntemi seçiminde ilave olarak değerlendirilen unsurlardandır. Sadece ofislerle sınırlı kalmayıp, farklı çalışma ortamlarında uygulanabilecek ve kas iskelet sistemi rahatsızlık düzeyleri ile bu rahatsızlıklarla karşılaşma sıklığını da tespit eden bir anket olarak, Cornell Üniversitesi İnsan Faktörleri ve Ergonomi Laboratuvarı tarafından geliștirilen, Cornell Musculoskeletal Discomfort Questionnaire (Cornell KİS Rahatsızlık Anketi-CMDQ) faydalı bir veri toplama aracı olarak ön plana çıkmaktadır(Özkan ve Kahya, 2017). Orijinal anket Erdinc vd. (2011) tarafından T-CMDQ anketi olarak Türkçe'ye uyarlanmış, geçerlilik ve güvenilirliği test edilmiştir. Anket ile 18 vücut bölümü incelenmektedir(Şekil 5). T-CMDQ anketinde oturarak çalışanlar için (sedentary workers) oluşturulmuş versiyon kullanılmıştır. Hissedilen rahatsızlıkların son 1 hafta içerisindeki frekans, şiddet ve işe engel durumu 3 soru ile değerlendirilmektedir.

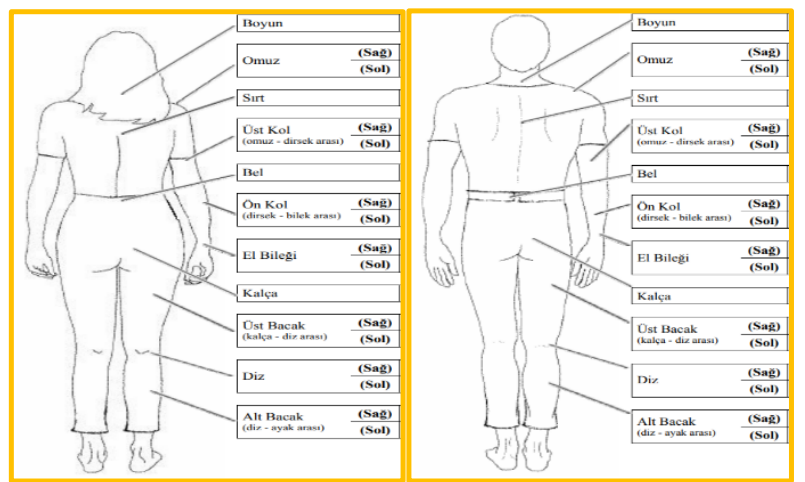

Şekil 5. Oturarak Çalışan Kadın-Erkek Vücut Bölümleri (T-CMDQ) (Erdinç vd., 2011)

Sıklık, şiddet, ișe engel durumu skorlarının çarpımı ile vücut bölümünün toplam rahatsızlık skoru bir başka değişle bölgenin risk puanı bulunmaktadır (Şekil-6). Bu çalışmada, vücudun hem sağ hem de sol tarafı için ayrı ayrı doldurulan omuz, üst kol, ön kol, bilek, üst bacak, diz, alt bacak bölgeleri risk değerleri arasında iki taraftaki risk puanlarından daha yüksek olan o bölgenin risk puanı olarak alınmıştır. Anket sonucunda her bölge için alınacak en yüksek skor 90, en düşük skor 0 olmaktadır. 


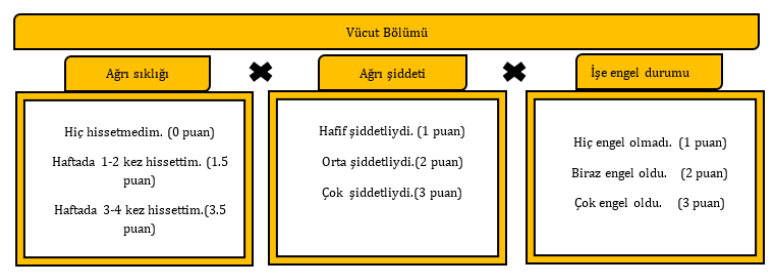

Şekil 6. Puanlandırma Skalası

\subsection{Bireysel Güç Kontrol Listesi}

CIS, yorgunluğu değerlendirmek amacıyla dünya çapında en yaygın uygulanan ankettir(Ergin, 2009). Üniversite öğrencilerinin genel yorgunluk seviyelerini ölçmek için Beurskens vd. (2000) tarafından geliștirilen , Ergin (2009) tarafından CIS$\mathrm{T}$ olarak Türkçe versiyonu geçerli olan anket kullanılarak öğrencilerin yorgunluk düzeyleri belirlenmiştir. Toplam yorgunluk; subjektif yorgunluk, konsantrasyon, motivasyon ve fiziksel aktivite alt boyutlarının farklı parametrelerde değerlendirilmesi ile ortaya konulmaktadır(Bedir vd., 2018). Anket, yorgunluğun son 2 hafta içerisindeki durumuna yönelik 20 ifadeden oluşmaktadır. Bu ifadelere verilen cevaplar için 7 puanlık skala kullanılmaktadır. Anket sonucunda alınabilecek en yüksek skor 140 olmaktadır. Çalışmada, subjektif yorgunluk, öğrencilerin kendini ne kadar yorgun, bitkin, güçsüz hissettiğine; konsantrasyon, düşünme ve dikkat toplama yeteneklerine; motivasyon, geleceğe dair plan ve isteklerine, fiziksel aktivite ise gün içindeki iş kapasitesine ışık tutmaktadır.

\section{3 İstatistiksel Analiz}

Popülasyon hakkında çıkarımlar yapılmasını gerektiren durumlarda örneklem büyüklüğü oldukça önemlidir. Çalışmada bu büyüklük belirlenirken, Cochran tarafindan önerilen denklemden yararlanılmıștır(Cochran, 1963). \%95 güven aralığı için, \%10 hata payı ile en az 78 adet örneğe ihtiyaç duyulacağı sonucuna varılmıştır. Denklemde popülasyon büyüklüğü ve örneklemin popülasyon oranı değerleri için Şekil 7'de verilen sayısal değerler dikkate alınmıștır. Çalıșma sonucunda ulaşılan örneklem büyüklüğü 154 'tür. Anketten elde edilen veriler, SPSS 22.00 programına aktarılmıştır(IBM SPSS Statistics for Windows, 2013). Değişkenlere uygulanan testlerde anlamlılık değeri $p \leq 0.05$ olarak kabul edilmiştir. Kategorik veriler frekans ve yüzde (\%) değerleri ile anket sonuçlarına ait veriler ortalama ve standart sapma değerleri ile gösterilmiştir. Shapiro-Wilk testi ile verilerin normal dağılımı araștırılmıștır ve normal dağılım gösteren verilerin istatistiksel analizi için "Bağımsız Gruplar ttesti", normal dağılım göstermeyen verilerde ise "Mann Whitney testi" kullanılmıştır.

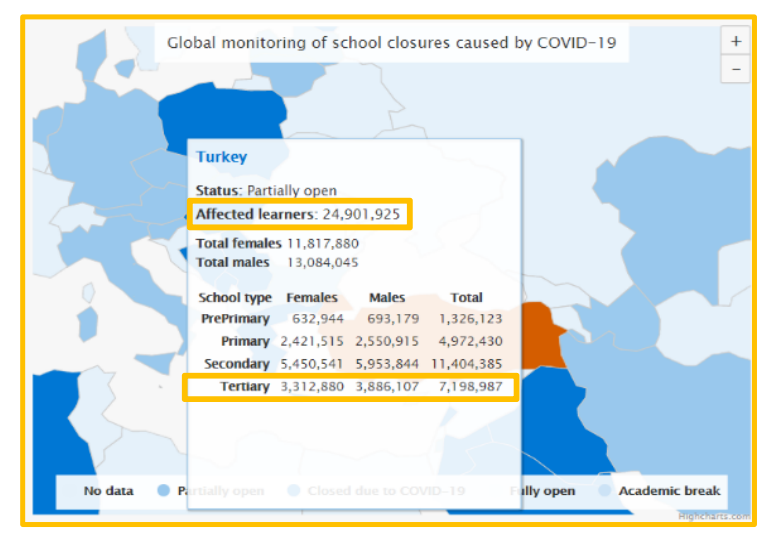

Şekil 7. Covid-19 Nedeni ile Okul Kapanışlarından Etkilenen Öğrenci Sayısı Türkiye (Global monitoring of school closures, 2020)

\section{Bulgular}

\subsection{Genel Bulgular}

Ankete katılan öğrencilere ait bilgiler Tablo-2'de verilmiștir. Öğrencilerin yaş ortalaması 21,83 (std. sapma 3,28) tür. Katılımcıların büyük bir çoğunluğu pandemi döneminde düzenli herhangi bir fiziksel aktivite yapmamakta $(\% 66,9)$ ve kendilerini yorgun hissetmektedir $(\% 85,1)$. Katılımclların \%57,1'i kadın, \%42,9'u erkektir ve $\% 89$ 'unun ise 24 yaş ve altı öğrencilerden oluştuğu belirlenmiştir.

Tablo 2. Demografik Özellikler-Genel Bilgiler

\begin{tabular}{|l|c|c|c|}
\hline Kategori & Frekans & $\begin{array}{c}\text { Yüzde } \\
\text { (\%) }\end{array}$ \\
\hline \multirow{2}{*}{ Cinsiyet } & Kadın & 88 & 57,1 \\
\cline { 2 - 4 } & Erkek & 66 & 42,9 \\
\hline \multirow{2}{*}{ Yaş } & $\leq 24$ & 137 & $\mathbf{8 9}$ \\
\cline { 2 - 4 } & $>24$ & 17 & 11 \\
\hline \multirow{2}{*}{ Lisans Eğitim Yllı } & 1 & 39 & 25,3 \\
\cline { 2 - 4 } & 2 & 54 & 35,1 \\
\cline { 2 - 4 } & 3 & 35 & 22,7 \\
\cline { 2 - 4 } & 4 & 17 & 11 \\
\cline { 2 - 4 } & $>4$ & 9 & 5,8 \\
\hline \multirow{2}{*}{$\begin{array}{l}\text { Düzenli fiziksel } \\
\text { aktivite yapma }\end{array}$} & Evet & 51 & 33,1 \\
\hline \multirow{2}{*}{$\begin{array}{l}\text { Yorgunluk hissi } \\
\text { var mı? }\end{array}$} & Hayır & 103 & $\mathbf{6 6 , 9}$ \\
\cline { 2 - 4 } & Hayıt & 131 & $\mathbf{8 5 , 1}$ \\
\hline \multirow{2}{*}{} & & 23 & 14,9 \\
\hline
\end{tabular}

Öğrencilerin biyolojik ritim ve uyku durumlarına ait bilgiler Tablo-3 'de verilmiștir. Pandemi döneminde öğrencilerin \%75,3'ünün uyku düzenleri bozulmuştur. Çevrimiçi ders izlemek veya çalışmak için gün 2 saat dilimine ayrılmıştır: 06.00-19.00 (gündüz), 19.00-06.00(gece). Katılımcıların \%49,4'ü gece saatlerinde aktif olarak çalışmaktadır. 
Tablo 3. Uyku ve Ders İzlence Zaman Dilimleri (Biyolojik Ritim)

\begin{tabular}{|l|c|c|c|}
\hline Kategori & & $\mathrm{N}$ & $\%$ \\
\hline $\begin{array}{l}\text { Uyku düzeniniz } \\
\text { bozuldu mu? }\end{array}$ & Evet & 116 & $\mathbf{7 5 , 3}$ \\
\cline { 2 - 4 } & Hayır & 38 & 24,7 \\
\hline Ders için saat dilimi & $06.00-19.00$ & 78 & 50,6 \\
\cline { 2 - 4 } & $19.00-06.00$ & 76 & 49,4 \\
\hline
\end{tabular}

Öğrencilerin pandemi döneminde derse katılım şekli, öğrenme ortamı, ders izleme süreleri Tablo-4 'de verilmiştir. Büyük bir çoğunluğu eğitim faaliyetleri için laptop kullanmaktadır $(\% 81,8)$. Derse katılırken masa başında oturma oranı yüksektir(\%64,9). Eğitim için cihazda geçirilen sürede ise öğrencilerin \%73,4'ünün 6 saatten az kullanımı söz konusudur. Öğrencilerin \%66,2 ‘si bu kullanım sırasında oturma şekline dikkat etmemektedir.

Tablo 4. Derse Katılım Şekli, Öğrenme Ortamı, İzleme Süreleri

\begin{tabular}{|c|c|c|c|}
\hline Kategori & & $\mathrm{N}$ & $\%$ \\
\hline \multirow[t]{4}{*}{ Cihaz } & Laptop & 126 & 81,8 \\
\hline & Masaüstü Bilgisayar & 6 & 3,9 \\
\hline & Telefon & 21 & 13,6 \\
\hline & Tablet & 1 & 0,6 \\
\hline \multirow[t]{5}{*}{ Derse Katılım Yeri } & Masa başı & 100 & 64,9 \\
\hline & Koltuk-Kanepe & 25 & 16,2 \\
\hline & Sandalye & 22 & 14,3 \\
\hline & Yer & 2 & 1,3 \\
\hline & Diğer & 5 & 3,2 \\
\hline \multirow{2}{*}{$\begin{array}{l}\text { Cihaz günlük } \\
\text { Kullanım Süresi }\end{array}$} & $\leq 6$ & 113 & 73,4 \\
\hline & $>6$ & 41 & 26,6 \\
\hline \multirow{2}{*}{$\begin{array}{l}\text { Oturma şekline dikkat } \\
\text { eder mi? }\end{array}$} & Evet & 52 & 33,8 \\
\hline & Hayır & 102 & 66,2 \\
\hline
\end{tabular}

\subsection{CIS-T Anket Bulguları}

Öğrencilerin sahip olduğu yorgunluğun farklı parametrelerden ileri gelen seviyeleri Tablo-5'de verilmiştir. Toplam yorgunluğun alt parametre puan ortalamaları, subjektif yorgunluk için 38,03 (std. sapma 10,96), konsantrasyon için 22,90 (std. sapma 7,09 ), motivasyon için 15,11 (std. sapma 4,70 ) ve fiziksel aktivite değerlerinde 13,46 (std. sapma 4,78) olarak bulunmuştur.
Tablo 5. Yorgunluk Seviyesine İlişkin Puanlar

\begin{tabular}{|l|l|}
\hline Alt Boyut & $\mathbf{x}+\mathbf{s s}$ \\
\hline Subjektif Yorgunluk & $38,03 \pm 10,96$ \\
\hline Konsantrasyon & $22,90 \pm 7,09$ \\
\hline Motivasyon & \\
\hline Fiziksel Aktivite & $15,11 \pm 4,70$ \\
\hline Toplam & $\mathbf{8 9 , 4 9 \pm 2 3 , 2 1}$ \\
\hline
\end{tabular}

Yorgunluk seviyesine ilişkin değerler, toplam yorgunluğun 89,49(std. sapma 23,21) olarak puanladığını ve subjektif yorgunluğun tüm yorgunluk alt boyutları içerisinde yüksek bir ortalamaya sahip olduğunu göstermektedir.

CIS-T anket bulgularına ait verilerde parametrik testlerin ön şartlarından olan normallik dağılım durumuna, Shapiro-Wilk testi ile bakılmıştır ve verilerin $\% 95$ güvenle normal dağıldığı görülmüștür $(p>0,05)$. Levene (varyansların eşitliği) testi yapılmış ve cinsiyet, hissedilen yorgunluk, oturma șekli, uyku bozukluğu ile yorgunluk ilişkisinin varyanslarının homojen dağıldı ğı görülmüştür $(p>0,05)$. İstatistiksel analizler için "Bağımsız Gruplar t-Testi" uygulanmıștır (Tablo $6,7,8,9)$.

Yorgunluk seviyesi ve cinsiyet değişkeni arasındaki ilişkiye ait istatistiksel sonuçlar incelendiğinde, subjektif yorgunluk, konsantrasyon, fiziksel aktivite ve toplam yorgunluğun cinsiyete göre CIS-T puan ortalamaları arasında istatistiksel olarak anlamlı farklılık olduğunu göstermektedir $(\mathrm{p} \leq 0.05)$ (Tablo6). Kadınların erkeklere göre bu 4 yorgunluk seviyesinde daha yüksek düzeyde yorgunluk gösterdiği bulunmuştur. Motivasyon yorgunluk alt boyutu ile cinsiyet arasinda anlamlı fark bulunamamıştır ( $p>0.05)$.

Tablo 6. Yorgunluk Seviyesinin Cinsiyete Göre İncelenmesi

\begin{tabular}{|c|c|c|c|c|c|c|}
\hline Alt Boyut & $\begin{array}{l}\text { Cinsiy } \\
\text { et }\end{array}$ & $\mathbf{N}$ & $\overline{\mathbf{x}}$ & ss & $\mathbf{p}$ & $\begin{array}{c}\text { Anlamlı } \\
\text { Fark }\end{array}$ \\
\hline \multirow{3}{*}{$\begin{array}{l}\text { Subjektif } \\
\text { Yorgunluk }\end{array}$} & Kadın & 8 & 40,0 & 10,7 & \multirow{3}{*}{$\begin{array}{l}0,007 \\
\quad *\end{array}$} & \multirow{3}{*}{$\begin{array}{c}\text { Var } \\
\text { Kadın>Erk } \\
\text { ek }\end{array}$} \\
\hline & & 8 & 7 & 5 & & \\
\hline & Erkek & $\begin{array}{l}6 \\
6\end{array}$ & $\begin{array}{l}35,3 \\
0\end{array}$ & $\begin{array}{l}10,7 \\
3\end{array}$ & & \\
\hline \multirow{3}{*}{$\begin{array}{l}\text { Konsantrasy } \\
\text { on }\end{array}$} & Kadın & 8 & 24,4 & 6,81 & \multirow{3}{*}{$\begin{array}{c}0,002 \\
*\end{array}$} & \multirow{3}{*}{$\begin{array}{c}\text { Var } \\
\text { Kadın>Erk } \\
\text { ek }\end{array}$} \\
\hline & & 8 & 2 & & & \\
\hline & Erkek & $\begin{array}{l}6 \\
6\end{array}$ & $\begin{array}{l}20,8 \\
6\end{array}$ & 6,99 & & \\
\hline \multirow[t]{2}{*}{ Motivasyon } & Kadın & 8 & 15,4 & 4,63 & \multirow[t]{2}{*}{0,329} & \multirow{2}{*}{$\begin{array}{c}\text { Yok } \\
-\end{array}$} \\
\hline & Erkek & $\begin{array}{l}6 \\
6\end{array}$ & $\begin{array}{l}14,6 \\
8\end{array}$ & 4,80 & & \\
\hline \multirow{3}{*}{$\begin{array}{l}\text { Fiziksel } \\
\text { Aktivite }\end{array}$} & Kadın & 8 & 14,1 & 4,71 & \multirow{3}{*}{$\begin{array}{c}0,028 \\
*\end{array}$} & \multirow{3}{*}{$\begin{array}{c}\text { Var } \\
\text { Kadın>Erk } \\
\text { ek }\end{array}$} \\
\hline & & 8 & 9 & & & \\
\hline & Erkek & $\begin{array}{l}6 \\
6\end{array}$ & $\begin{array}{l}12,4 \\
8\end{array}$ & 4,73 & & \\
\hline Toplam & Kadın & $\begin{array}{l}8 \\
8\end{array}$ & $\begin{array}{l}94,1 \\
1\end{array}$ & $\begin{array}{l}22,6 \\
4\end{array}$ & $\begin{array}{c}0,004 \\
*\end{array}$ & Var \\
\hline
\end{tabular}




\begin{tabular}{|l|l|l|l|l|l|c|}
\hline & Erkek & 6 & 83,3 & 22,6 & & Kadın>Erk \\
& & 6 & 3 & 8 & & ek \\
\hline${ }^{*}(\mathrm{p} \leq 0.05)$
\end{tabular}

Öğrencilerin kendilerini yorgun hissetme hali ile CIS$\mathrm{T}$ anketinden elde edilen nümerik yorgunluk değerleri arasındaki ilişki değerlendirildiğinde tüm yorgunluk parametrelerine göre anlamlı farklılık belirlenmiştir $(\mathrm{p} \leq 0.05)($ Tablo-7). $\mathrm{Bu}$ sonuç, öğrencilerin pandemi döneminde bireysel olarak kendilerini yorgun hissetme hali ile CIS-T anketine verilen cevaplar arasında anlamlılık olduğunu göstermektedir.

\section{Tablo 7. Yorgunluk Seviyesinin Öğrencilerin} Hissettiği Yorgunluğa Göre İncelenmesi

\begin{tabular}{|c|c|c|c|c|c|c|}
\hline Alt Boyut & Yorgunluk Hissi & $\mathbf{N}$ & $\overline{\mathbf{x}}$ & ss & P & $\begin{array}{c}\text { Anlamlı } \\
\text { Fark }\end{array}$ \\
\hline \multirow{2}{*}{$\begin{array}{l}\text { Subjektif } \\
\text { Yorgunluk }\end{array}$} & Evet & 131 & 40,44 & 9,29 & \multirow[t]{2}{*}{$0,000^{*}$} & \multirow{2}{*}{$\begin{array}{c}\text { Var } \\
\text { Evet }>\text { Haylr }\end{array}$} \\
\hline & Hayrr & 23 & 24,26 & 9,65 & & \\
\hline \multirow[t]{2}{*}{ Konsantrasyon } & Evet & 131 & 23,97 & 6,69 & \multirow[t]{2}{*}{$0,000^{*}$} & \multirow{2}{*}{$\begin{array}{c}\text { Var } \\
\text { Evet } \gg \text { Hayrr }\end{array}$} \\
\hline & Hayrr & 23 & 16,78 & 6,22 & & \\
\hline \multirow[t]{2}{*}{ Motivasyon } & Evet & 131 & 15,89 & 4,43 & \multirow[t]{2}{*}{$0,000^{*}$} & \multirow{2}{*}{$\begin{array}{c}\text { Var } \\
\text { Evet }>\text { Hayır }\end{array}$} \\
\hline & Hayrr & 23 & 10,70 & 3,69 & & \\
\hline \multirow{2}{*}{$\begin{array}{l}\text { Fiziksel } \\
\text { Aktivite }\end{array}$} & Evet & 131 & 14,11 & 4,56 & \multirow[t]{2}{*}{$0,000^{*}$} & \multirow{2}{*}{$\begin{array}{c}\text { Var } \\
\text { Evet }>\text { Hayır }\end{array}$} \\
\hline & Hayrr & 23 & 9,74 & 4,37 & & \\
\hline \multirow[b]{2}{*}{ Toplam } & Evet & 131 & 94,41 & 20,1 & \multirow[t]{2}{*}{$0,000^{*}$} & \multirow{2}{*}{$\begin{array}{c}\text { Var } \\
\text { Evet } \gg \text { Hayır }\end{array}$} \\
\hline & Hayrr & 23 & 61,48 & 19,86 & & \\
\hline
\end{tabular}

$*(\mathrm{p} \leq 0.05)$

Katılımcıların büyük çoğunluğu(\%66,2) çevrimiçi dersler süresince oturma pozisyonuna dikkat etmemektedir. $\mathrm{Bu}$ pozisyona olan dikkat ve yorgunluk seviyesi arasındaki ilişki Tablo-8'de verilmiştir. Oturma şekli dikkati ile tüm yorgunluk parametreleri arasında anlamlı farklılık vardır $(p \leq 0.05)$. İstatistiksel analiz sonucu, çevrimiçi dersleri dinleme esnasında oturma şekline dikkat etmeyen öğrencilerin daha yüksek yorgunluk puan ortalamasına sahip olduğunu göstermektedir.

Tablo 8. Yorgunluk Seviyesinin Oturma Şekli Dikkatine Göre İncelenmesi

\begin{tabular}{|c|c|c|c|c|c|c|}
\hline Alt Boyut & $\begin{array}{l}\text { Oturma Şekline } \\
\text { Dikkat Eder mi? }\end{array}$ & $\mathrm{N}$ & $\overline{\mathbf{x}}$ & ss & p & $\begin{array}{c}\text { Anlaml } \\
\text { Fark }\end{array}$ \\
\hline \multirow{2}{*}{$\begin{array}{l}\text { Subjektif } \\
\text { Yorgunluk }\end{array}$} & Evet & 52 & 34,1 & 10,08 & \multirow[t]{2}{*}{$0,001^{*}$} & \multirow{2}{*}{$\begin{array}{c}\text { Var } \\
\text { Hayır }>\text { Evet }\end{array}$} \\
\hline & Hayrr & 102 & 40,03 & 10,9 & & \\
\hline \multirow[t]{2}{*}{ Konsantrasyon } & Evet & 52 & 19,33 & 5,83 & \multirow[t]{2}{*}{$0,000^{*}$} & \multirow{2}{*}{$\begin{array}{c}\text { Var } \\
\text { Hayır }>\text { Evet }\end{array}$} \\
\hline & Hayrr & 102 & 24,72 & 7 & & \\
\hline \multirow[t]{2}{*}{ Motivasyon } & Evet & 52 & 14,04 & 4,29 & \multirow[t]{2}{*}{$0,036^{*}$} & \multirow{2}{*}{$\begin{array}{c}\text { Var } \\
\text { Hayır>Evet }\end{array}$} \\
\hline & Hayrr & 102 & 15,66 & 4,82 & & \\
\hline \multirow{2}{*}{$\begin{array}{l}\text { Fiziksel } \\
\text { Aktivite }\end{array}$} & Evet & 52 & 11,17 & 4,54 & \multirow[t]{2}{*}{$0,000^{*}$} & \multirow{2}{*}{$\begin{array}{c}\text { Var } \\
\text { Hayır }>\text { Evet }\end{array}$} \\
\hline & Hayrr & 102 & 14,63 & 4,49 & & \\
\hline \multirow[b]{2}{*}{ Toplam } & Evet & 52 & 78,63 & 19,72 & \multirow[t]{2}{*}{$0,000^{*}$} & \multirow{2}{*}{$\begin{array}{c}\text { Var } \\
\text { Hayır }>\text { Evet }\end{array}$} \\
\hline & Hayır & 102 & 95,02 & 22,98 & & \\
\hline
\end{tabular}

$*(\mathrm{p} \leq 0.05)$

Pandemi döneminde öğrencilerin uyku düzenlerinin bozulma durumunun yorgunluk seviyesi üzerinde etkili olup olmayacağına dair değerlendirme Tablo9 'da verilmiştir. Subjektif yorgunluk, konsantrasyon, fiziksel aktivite ve toplam yorgunluğun uyku düzeninin bozulmasından etkilendiği, uyku düzeni ve bu 4 yorgunluk alt boyutu arasinda istatistiksel olarak anlamlı farklılı olduğu görülmektedir $(\mathrm{p} \leq 0.05)$. Motivasyon yorgunluk alt boyutu ile uyku düzeni bozukluğu arasında anlamlı fark bulunamamıştır ( $p>0.05)$.

Tablo 9. Yorgunluk Seviyesinin Uyku Düzeni Bozukluğuna Göre İncelenmesi

\begin{tabular}{|c|c|c|c|c|c|c|}
\hline Alt Boyut & $\begin{array}{l}\text { Uyku Düzeniniz } \\
\text { Bozuldu mu? }\end{array}$ & $\mathbf{N}$ & $\overline{\mathbf{x}}$ & ss & p & $\begin{array}{c}\text { Anlamlı } \\
\text { Fark }\end{array}$ \\
\hline \multirow{2}{*}{$\begin{array}{l}\text { Subjektif } \\
\text { Yorgunluk }\end{array}$} & Evet & 116 & 39,68 & 10,70 & \multirow[t]{2}{*}{$0,001^{*}$} & \multirow{2}{*}{$\begin{array}{c}\text { Var } \\
\text { Evet }>\text { Hayır }\end{array}$} \\
\hline & Hayrr & 38 & 32,97 & 10,32 & & \\
\hline \multirow[t]{2}{*}{ Konsantrasyon } & Evet & 116 & 24,13 & 6,97 & \multirow[t]{2}{*}{$0,000^{*}$} & \multirow{2}{*}{$\begin{array}{c}\text { Var } \\
\text { Evet>Hayır }\end{array}$} \\
\hline & Hayır & 38 & 19,13 & 6,13 & & \\
\hline \multirow[t]{2}{*}{ Motivasyon } & Evet & 116 & 15,39 & 4,71 & \multirow[t]{2}{*}{0,201} & \multirow{2}{*}{ Yok } \\
\hline & Haylr & 38 & 14,26 & 4,63 & & \\
\hline \multirow[t]{2}{*}{ Fiziksel Aktivite } & Evet & 116 & 14,26 & 4,49 & \multirow[t]{2}{*}{$0,000^{*}$} & \multirow{2}{*}{$\begin{array}{c}\text { Var } \\
\text { Evet>Hayır }\end{array}$} \\
\hline & Hayrr & 38 & 11 & 4,85 & & \\
\hline \multirow[b]{2}{*}{ Toplam } & Evet & 116 & 93,46 & 22,55 & \multirow[t]{2}{*}{$0,000^{*}$} & \multirow{2}{*}{$\begin{array}{c}\text { Var } \\
\text { Evet }>\text { Hayır }\end{array}$} \\
\hline & Hayır & 38 & 77,37 & 21,12 & & \\
\hline
\end{tabular}

\subsection{T-CMDQ Anket Bulguları}

Cornell anketi vücut bölgelerine göre toplam risk puanları Tablo 10'da verilmiştir. Cornell verilerinin normallik dağılım durumuna Shapiro-Wilk testi ile bakılmıştır ve \%95 güvenle normal dağılım sergilemediği görülmüștür $(p \leq 0,05)$. Bu sebeple, istatistiksel analiz için non-parametrik test olan "Mann Whitney testi" uygulanmıştır (Tablo11,12,13,14). Puanlar, öğrencilerin Covid-19 döneminde son bir hafta içerisinde bel $(\% 18,26)$, sirt $(\% 17,02)$, boyun $(\% 16,81)$ ve omuz $(\% 11,54)$ bölgelerinin en çok zorlanma yaşadıkları bölgeler olduğu görülmektedir. Anket sonuçlarına dayalı istatistiksel analizler en yüksek zorlanma oranına sahip bu 4 bölge için yapılmıștır.

Tablo 10. Rahatsızlık Puanlarının Bölgelere Göre Yüzde Dağılımları

\begin{tabular}{|l|c|c|c|}
\hline \multicolumn{1}{|c|}{ Vücut Bölgesi } & $\begin{array}{c}\text { Toplam } \\
\text { Risk Puanı }\end{array}$ & $\begin{array}{c}\text { Ortalama } \\
\text { Risk Puanı }\end{array}$ & \% \\
\hline Boyun & 2795 & 18,15 & $\mathbf{1 6 , 8 1}$ \\
\hline Omuz & 1918 & 12,45 & $\mathbf{1 1 , 5 4}$ \\
\hline Sırt & 2829,5 & 18,37 & $\mathbf{1 7 , 0 2}$ \\
\hline $\begin{array}{l}\text { Üst Kol-Omuz Dirsek } \\
\text { Arası }\end{array}$ & 627,5 & 4,07 & 3,77 \\
\hline Bel & 3035,5 & 19,71 & $\mathbf{1 8 , 2 6}$ \\
\hline $\begin{array}{l}\text { Ön Kol-Dirsek Bilek } \\
\text { Arası }\end{array}$ & 606,5 & 3,94 & 3,65 \\
\hline Bilek & 1282 & 8,32 & 7,71 \\
\hline Kalça & 1485,5 & 9,65 & 8,94 \\
\hline $\begin{array}{l}\text { Üst Bacak-Kalça Diz } \\
\text { Arası }\end{array}$ & 643 & 4,18 & 3,87 \\
\hline Diz & 353 & 2,29 & 2,12 \\
\hline $\begin{array}{l}\text { Alt Bacak -Diz Ayak } \\
\text { Arası }\end{array}$ & 1049 & 6,81 & 6,31 \\
\hline
\end{tabular}

Bel, sırt, boyun ve omuz bölgeleri rahatsızlık puanları ile öğrencilerin cinsiyeti Tablo-14'de verilmiştir. Cinsiyet ve puanlar arasında anlamlı farklılık bulunmuştur $(\mathrm{p} \leq 0.05)$. Sonuçlara göre bu bölgeler için kadınlar erkeklerden daha yüksek zorlanma puanına sahiptir. 
Tablo 11. Rahatsızlık Puanlarının Cinsiyete Göre İncelenmesi

\begin{tabular}{|c|c|c|c|c|c|}
\hline $\begin{array}{l}\text { Alt } \\
\text { Boyut }\end{array}$ & Cinsiyet & $\mathbf{N}$ & $\begin{array}{l}\text { Mean } \\
\text { Ranर̄ }\end{array}$ & $\mathbf{p}$ & $\begin{array}{c}\text { Anlamlı } \\
\text { Fark }\end{array}$ \\
\hline \multirow[t]{2}{*}{ Bel } & Kadın & 88 & 87,59 & \multirow[t]{2}{*}{$0,001^{*}$} & \multirow{2}{*}{$\begin{array}{c}\text { Var } \\
\text { Kadın>Erkek }\end{array}$} \\
\hline & Erkek & 66 & 64,05 & & \\
\hline \multirow[t]{2}{*}{ Sirt } & Kadın & 88 & 89,68 & \multirow[t]{2}{*}{$0,000^{*}$} & \multirow{2}{*}{$\begin{array}{c}\text { Var } \\
\text { Kadın>Erkek }\end{array}$} \\
\hline & Erkek & 66 & 61,26 & & \\
\hline \multirow[t]{2}{*}{ Boyun } & Kadın & 88 & 87,02 & \multirow[t]{2}{*}{$0,002^{*}$} & \multirow{2}{*}{$\begin{array}{c}\text { Var } \\
\text { Kadın>Erkek }\end{array}$} \\
\hline & Erkek & 66 & 64,80 & & \\
\hline \multirow[t]{2}{*}{ Omuz } & Kadın & 88 & 86,72 & \multirow[t]{2}{*}{$0,002^{*}$} & \multirow{2}{*}{$\begin{array}{c}\text { Var } \\
\text { Kadın>Erkek }\end{array}$} \\
\hline & Erkek & 66 & 65,21 & & \\
\hline
\end{tabular}

Öğrencilerin çevrimiçi ders izlemek veya çalışmak için kullandıkları 06.00-19.00 (gündüz) ve 19.0006.00 (gece) saat dilimleri ile Cornell rahatsızlık puanlarına ait bilgiler Tablo-12'de verilmiştir. Sonuçlar, Cornell puanları için en çok zorlanmaya sahip 4 bölgeden yalnızca omuz bölgesinde ders izlenen saat dilimi arasında anlamlı farklılık olduğunu göstermektedir $(\mathrm{p} \leq 0.05)$. Bel, sırt ve boyun bölgesi ile seçilen saat dilimi arasında anlamlı fark bulunamamıştır ( $\mathrm{p}>0.05)$.

Tablo 12. Rahatsızlık Puanlarının Ders İzlenen Saat Dilimine Göre İncelenmesi

\begin{tabular}{|c|c|c|c|c|c|}
\hline $\begin{array}{l}\text { Alt } \\
\text { Boyut }\end{array}$ & Saat Dilimi & N & $\begin{array}{l}\text { Mean } \\
\text { Ranर }\end{array}$ & $\mathbf{p}$ & Anlamlı Fark \\
\hline \multirow[t]{2}{*}{ Bel } & $06.00-19.00$ & 78 & 74,94 & \multirow[t]{2}{*}{0,468} & \multirow{2}{*}{ Yok } \\
\hline & $19.00-06.00$ & 76 & 80,13 & & \\
\hline \multirow[t]{2}{*}{ Sirt } & $06.00-19.00$ & 78 & 74,04 & \multirow[t]{2}{*}{0,328} & \multirow{2}{*}{ Yok } \\
\hline & $19.00-06.00$ & 76 & 81,05 & & \\
\hline \multirow[t]{2}{*}{ Boyun } & $06.00-19.00$ & 78 & 75,01 & \multirow[t]{2}{*}{0,478} & \multirow{2}{*}{$\begin{array}{c}\text { Yok } \\
-\end{array}$} \\
\hline & $19.00-06.00$ & 76 & 80,06 & & \\
\hline \multirow[t]{2}{*}{ Omuz } & $06.00-19.00$ & 78 & 70,35 & \multirow[t]{2}{*}{$0,038^{*}$} & \multirow{2}{*}{$\begin{array}{c}\text { Var } \\
19.00-06.00>06.00-19.00\end{array}$} \\
\hline & $19.00-06.00$ & 76 & 84,84 & & \\
\hline
\end{tabular}

$*(\mathrm{p} \leq 0.05)$

Tablo-13, uyku düzeni ve ilgili bölgelere ait Cornell rahatsızlık puanlarını göstermektedir. Sırt ve boyun bölgesi rahatsızlı puanlarının uyku düzeni bozukluğuna göre anlamlı düzeyde yüksek olduğu belirlenmiştir $(p \leq 0.05)$. Bel ve omuz bölgesi ile uyku düzeni arasında anlamlı fark bulunamamıştır ( $>>0.05)$.

Tablo 13. Rahatsızlık Puanlarının Uyku Düzeni Bozukluğuna Göre İncelenmesi

\begin{tabular}{|c|c|c|c|c|c|}
\hline $\begin{array}{l}\text { Alt } \\
\text { Boyut }\end{array}$ & $\begin{array}{l}\text { Uyku } \\
\text { Düzeniniz } \\
\text { Bozuldu } \\
\text { mu? }\end{array}$ & $\mathbf{N}$ & $\begin{array}{l}\text { Mean } \\
\text { Rank̄ }\end{array}$ & $\mathbf{p}$ & $\begin{array}{c}\text { Anlamlı } \\
\text { Fark }\end{array}$ \\
\hline \multirow[t]{2}{*}{ Bel } & Evet & 116 & 80,29 & \multirow[t]{2}{*}{0,173} & \multirow{2}{*}{$\begin{array}{c}\text { Yok } \\
-\end{array}$} \\
\hline & Hayır & 38 & 68,99 & & \\
\hline \multirow[t]{2}{*}{ Sirt } & Evet & 116 & 82,87 & \multirow[t]{2}{*}{$0,009^{*}$} & \multirow{2}{*}{$\begin{array}{c}\text { Var } \\
\text { Evet>Hayır }\end{array}$} \\
\hline & Hayır & 38 & 61,11 & & \\
\hline \multirow[t]{2}{*}{ Boyun } & Evet & 116 & 83,83 & \multirow[t]{2}{*}{$0,002^{*}$} & \multirow{2}{*}{$\begin{array}{c}\text { Var } \\
\text { Evet }>\text { Hayır }\end{array}$} \\
\hline & Hayır & 38 & 58,18 & & \\
\hline \multirow[t]{2}{*}{ Omuz } & Evet & 116 & 79,24 & \multirow[t]{2}{*}{0,383} & Yok \\
\hline & Hayır & 38 & 72,18 & & - \\
\hline
\end{tabular}

Tablo-14'de T-CMDQ ve CIS-T puanları arasındaki korelasyon verilmiştir. Spearman korelasyon katsayısı (r) 0,416 olarak görülmektedir(p $\leq 0.01)$. Bu katsayı, CIS-T ve T-CMDQ puanları arasında pozitif yönlü bir ilișki olduğunu göstermektedir. Yorgunluk ve KISR arasındaki ilişki anlamlıdır.

Tablo 14. T- CMDQ ve CIS-T Toplam Puanların Korelasyonu

\begin{tabular}{|c|c|c|c|}
\hline & & T-CMDQ & CIS-T \\
\hline \multirow[t]{2}{*}{ T-CMDQ } & $r$ & 1 & 0,416 \\
\hline & $\mathrm{p}$ & - & $0,000^{*}$ \\
\hline \multirow[t]{2}{*}{ CIS-T } & $r$ & 0,416 & 1 \\
\hline & $\mathrm{p}$ & $0,000^{*}$ & - \\
\hline
\end{tabular}

*(p $\leq 0.01)$ r: Spearman's Korelasyon Katsayısı

\section{Tartışma}

Pandemi döneminde, yorgunluk ve kas-iskelet sistemi rahatsızlıkları bireylerde pandemi öncesine göre daha yoğun ve yaygın hissedilen semptonlar olarak karşımıza çıkmaktadır. Yapılan çalışmada uygulanan T-CMDQ anketi ile vücut bölümlerinde hissedilen rahatsılıklar ve CIS-T anketi ile öğrencilerin genel yorgunluk seviyeleri puanlandırılmıştır.

CIS-T yorgunluk anketi, yorgunluğu subjektif yorgunluk, konsantrasyon, motivasyon ve fiziksel aktivite boyutları ile incelemektedir. Yorgunluk puanlarına bakıldığında öğrencilerin subjektif yorgunluk yönünden yüksek ortalamaya sahip olduğu görülmektedir. Yorgunluk boyutları cinsiyete göre incelendiğinde, subjektif yorgunluk, konsantrasyon, fiziksel aktivite ve toplam yorgunluk için anlamlı farklar bulunmuştur. Kadınların erkeklere göre bu parametreler açısından daha yüksek puan ortalamasına sahip olduğu görülmüştür. Toplam yorgunluk 140 puan üzerinden 89,49 'dur. Yorgunluk düzeyine ek olarak, ankette "Pandemi döneminde genel olarak kendinizi yorgun hissetme haline sahip misiniz?" sorusuna yer verilmiş olup, öğrencilerin yorgunluğa karşı hisleri incelenmiştir. Katılımcıların \%85,1'i yorgun hissetme haline sahip olduklarını belirtmiştir. $\mathrm{Bu}$ hissedilen yorgunluk, CIS-T anketi toplam yorgunluk seviyesine göre değerlendirildiğinde, yorgunluk hisseden öğrenciler için aynı zamanda toplam yorgunluk değerlerinin de yüksek olduğu görülmüştür. Labrague ve Ballad (2020) üniversite öğrencilerinin Covid-19 karantina yorgunluğu düzeylerini incelemiş ve bu yorgunlukla başa çıkma davranışlarına kişisel dayanıklılığın ve psikolojik sağlığın rolü üzerine çalışmıştır. Fiziksel yorgunluk, baş ağrısı, vücut ağrısı, azalan motivasyon ve artan endişenin, yorgunluğun en belirgin belirtileri olarak ortaya çıktığını vurgulamıştır. Öğrencilerin karantinada yaşadıkları yorgunluk skor ortalaması 50 puan üzerinden 31,54 olarak belirlenmiştir. 
Yapılan çalışmada değerlendirilmek istenen bir diğer konu uyku düzeninin yorgunluğu nasıl etkilediğidir. $\mathrm{Bu}$ etkiyi incelemek için "Pandemi döneminde uyku düzeniniz bozuldu mu?" sorusuna yer verilmiștir. Katılımcıların \%75,3'ü bu dönemde uyku düzenlerinin bozulduğunu belirtmiştir. Yorgunluk seviyesi bu parametreye göre incelendiğinde, uyku düzeni bozulan öğrencilerin aynı zamanda toplam yorgunluk değerlerinde yüksek puana sahip oldukları belirlenmiştir. Uzaktan eğitimde oturma şekli önemli olan bir diğer unsurdur. Çevrimiçi eğitim döneminde, farklı cihazlar ile çalışırken oturma pozisyonu, yorgunluğu etkileyebilmektedir. Katılımcların \%66,2 'si derslere katılırken oturma şekline dikkat etmemektedir. Yorgunluk seviyesi çalışma esnasındaki oturma şekli dikkatine göre incelendiğinde toplam yorgunluk seviyesinde anlamlı fark bulunmuştur, $\mathrm{p} \leq 0.05$. Bu pozisyona dikkat etmeyenler daha yüksek yorgunluk puanına sahiptir.

Cornell rahatsızlık puanları da uyku düzeni bozukluğuna göre incelenmiş, sirt ve boyun bölgesinde anlamlı fark bulunmuştur, $\mathrm{p} \leq 0.05$. Uyku düzeni bozulan öğrencilerin, bu 2 bölge için yüksek puana sahip oldukları görülmüştür. Çalışmada ayrıca, biyolojik ritme yönelik değerlendirme de yapılmıştır. Günlük biyolojik ritim gün boyu oluşan davranışsal ve fizyolojik değişiklikleri içerir. (Özdemir ve Işık, 2020). Bu ritmin etkisini incelemek için çalışmada "Pandemi döneminde çevrimiçi ders izlemek veya çalışmak için ağırlıklı olarak hangi saat dilimini kullanıyorsunuz?" sorusuna yer verilmiştir. Çalışma saatleri 06.00-19.00 (gündüz) ve 19.0006.00 (gece) olarak 2' ye ayrılmıştır. Rahatsızlık puanları ders izlenen saat dilimine göre incelendiğinde omuz bölgesinde anlamlı farklılık olduğu görülmüștür p $\leq 0.05$. Gupta vd. (2020), kısıtlamaların uyku düzenine etkisini araştırmıştır. Çalışmanın sonuçları, Covid-19 ile birlikte geç yatma düzeninin değişmesi, gecikmiş uyku başlangıcı, gece uyku süresinde azalma ve gündüz uyuklamada artışı doğrulamıştır. Covid-19 dönemindeki uyku düzensizliğinin kalıcı olması durumunda, orta ve ileri yaşlar için farklı rahatsızlık boyutlarının da ortaya çıkması olasıdır. Sabina vd. (2021) yaptıkları çalışmada, uyku düzensizliği ve uyku süresi ilişkisini ele almıştır. Orta yaşlarda günde 6 saat ve daha az (gece) uyuyanlarda, günde 7 saat uyuyanlara göre ileri yaşlarda demans gelişme riski \%30 artmıştır. Demansa ek olarak diyabet, obezite, depresyon, yüksek tansiyon, gibi birçok rahatsızlığa neden olabilen uykusuzluk problemi pandemi döneminde sıkça görülen olumsuz bir sonuçtur ve bu durum Covid-19 dönemi öğrencilerinin ileri yaşları için de uzun dönemli olarak incelenmesi gereken bir konudur.

Cornell KİSR anketi ile öğrencilerin Covid-19 döneminde son bir hafta içerisinde en çok zorlanma yaşadıkları vücut alanlarının bel $(\% 18,26)$, sırt $(\% 17,02)$, boyun $(\% 16,81)$ ve omuz $(\% 11,54)$ bölgesi olduğu görülmektedir. Cornell sonuçlarına dayalı istatistiksel analizler yalnızca bu yüksek zorlanma oranına sahip 4 bölge üzerinden yapılmıștır. Rahatsızlık puanları cinsiyete göre incelendiğinde anlamlı farklılık bulunmuştur, $\mathrm{p} \leq 0.05$. Kadınların erkeklere göre daha yüksek zorlanma yaşadığı görülmüştür. Aytar vd. (2020) Covid-19 sırasında uzaktan eğitim alan öğrencilere yönelik kapsamlı postür ve ergonomi eğitimi, broşür ve çalışma ortamı düzenlemesi yaparak kas iskelet sistemi ağrılarına etkisini araștırmıștır. Genișletilmiș Nordic Kas İskelet Sistemi Anketi (NMQ-E) ile yapılan değerlendirmelerde, kas iskelet sistemi ağrısı ve aktivite önleme açısından anlamlı fark bulunamamıștır. Sipahioğlu ve Dik (2020) pandemi döneminde evden çalışma yapan bireylere CMDQ ve ROSA ergonomik risk analizlerini uygulamıştır. Çalışanların hissettiği KİSR ile evden çalışmalarda kullanılan ofis ekipmanlarının ve bunların kullanımının ergonomik açıdan incelenmesinde, birbirini destekleyen unsurlar olduğu belirtilmiștir. Kayabinar vd. (2021) ilkokul ve ortaokul düzeyinde eğitim veren öğretmenlerin, Covid-19 pandemisinde çevrimiçi eğitim nedeniyle oluşan kas-iskelet sistemi sorunları ve psikososyal durumlarındaki değişiklikleri araştırmıştır. Sonuçlar, CMDQ ile alınan toplam puan ve boyun, sağ omuz, sol omuz, sırt, sağ önkol, sağ bilek, sol bilek, bel ve kalça puanları dahil olmak üzere diğer puanların çevrimiçi eğitim öncesi ile karşılaştırıldığında önemli ölçüde daha yüksek olduğunu göstermiştir. Sarı vd. (2020) pandemi döneminde akademisyenlerin demografik özellikleri ve bilgisayar kullanım alışkanlıklarına bağlı olarak değişiklik gösteren üst ekstremite fonksiyonunu araştırmıştır. Kadınlar, erkeklere kıyasla daha yüksek CMDQ-T boyun, sirt ve bel puanı; günde ortalama 6 saat ve üzeri bilgisayar kullananlar, 6 saatten az kullananlara göre daha yüksek CMDQ-T boyun, omuz, sırt, üst kol, önkol puanı ve bilgisayarda herhangi bir ergonomik destek kullanan ve kullanmayan bireyler arasında değerlendirilen parametreler açısından anlamlı bir fark olmadığını belirlemiştir. Şengül vd. (2020) TCMDQ ile yaptıkları çalışmada, karantina dönemini ve öncesini kıyasladığında bel, boyun ve sırt ağrısında istatistiksel açıdan önemli bir artış bulunmuştur. Vücut bölgelerinde ağrı ve rahatsızlık hissetme sıklığında azalma olurken ortaya çıkan rahatsızlıkların şiddetinde artış olduğunu tespit etmişlerdir.

T-CMDQ ve CIS-T puanları ile yapılan Spearman korelasyon analizi sonucuna göre yorgunluk ve rahatsızlık arasında anlamlı ve olumlu bir ilişki olduğu bulunmuştur, $r=0,416, \mathrm{p} \leq 0.01$. 


\section{Sonuçlar}

$\mathrm{Bu}$ çalış̧mada, toplam 154 gönüllü katılımcıya çevrimiçi ortamda anket uygulanmış ve Covid-19 döneminde çevrimiçi eğitim alan üniversite öğrencilerinin yorgunluk değerleri, biyolojik ritim, uyku konusundaki düzenleri ile kas iskelet sistemi rahatsızlıkları değerlendirilmiştir.

Yorgunluk düzeyini değerlendirmeye yönelik uygulanan CIS-T anketi sonuçlarında öğrencilerin toplam yorgunluk düzeylerinin yüksek olduğu bulunmuştur. Kadınların, erkeklere göre daha büyük yorgunluk puanına sahip olması, öğrencilerin cinsiyet etkisine göre yorgunluğa bağlı rahatsızlık ve şikayetleri farklı boyutlarda yaşayacaklarını göstermiştir. Öğrencilerin gerçekte yorgunluk hissedip hissetmedikleri, hesaplanan yorgunluk puanı ile anlamlılık içermektedir. Bu durum hissettikleri yorgunluk olgusunun gerçekliğini sayısal olarak kanıtlar niteliktedir. Uyku düzeni bozulan öğrencilerin aynı zamanda daha yüksek yorgunluk seviyesine ulaştığı görülmüştür. Öğrencilerin çalışma ortamındaki oturma pozisyonuna dikkat etmemesi de yorulma düzeyini arttıran bir etkendir.

Kas-iskelet sistemi rahatsızlıklarını değerlendirmeye yönelik uygulanan Cornell anketi sonuçları, öğrencilerde oluşan rahatsızlıkların bel, sırt, boyun ve omuz bölgesinde yoğunlaştığını göstermiştir. Yorgunluk düzeyinde olduğu gibi rahatsızlık seviyesinde de kadınların daha fazla zorlanma yașadığı sonucu elde edilmiștir. Covid19'un KİSR için biyolojik ritim ve uyku üzerine etkisi, araştırılan bir diğer konudur. Uyku düzeni bozulan öğrencilerin sırt ve boyun bölgesinde daha yüksek zorlanma yaşadığı tespit edilmiştir. 24 saatlik zaman dilimi 2 ayrı parçaya bölünmüştür; 06.0019.00 (gündüz) ve 19.00-06.00 (gece). Katılımciların yarısının gece saatlerinde aktif olarak çalıştığı görülmüştür. Gece saat dilimini kullanan öğrencilerin omuz bölgesinde oluşan rahatsızlık puanı, gündüz saat dilimini kullananlara göre daha yüksektir. $\mathrm{Bu}$ farklılı̆ga, gece hücrelerdeki rejenerasyon sırasının omuz bölgesine gelmesi sebep olabilir. Vücutta hissedilen rahatsızlıklar ve yorgunluk seviyeleri birbiriyle pozitif ilişkilidir. Böylece, genel yorgunlukta hissedilen bir artışın, toplam yorgunluk düzeyini yükselteceği ve yorgunluk ile rahatsızlı arasındaki pozitif korelasyona bağlı olarak da bu durumun kas-iskelet sistemi rahatsızlıklarını arttıracağı öngörülmektedir.

Çalışmada, Covid-19 'un eğitim yaşamına etkisiyle, hızlı bir şekilde uzaktan eğitim süreçlerine adapte olan üniversite öğrencilerinin, bu dönemde oluşan yorgunluklar ve öğrencilerin dersler esnasında farklı vücut bölgelerinde yaşadıkları rahatsızlık değerleri nümerik olarak ortaya konulmuştur. Ders dinlemek, izlemek veya takip etmek için bulundukları çalışma alanı farklılıkları, cihaz farklılıkları, vücut pozisyonuna dikkat edilmemesi ve daha pek çok farklı neden ile vücut bölgelerinde oluşabilecek KISR'nın sadece pandemi dönemi ile sınırı kalmayıp öğrencilerin yaşamına uzun vadede etki edeceği düşünülmektedir.

Gelecek çalışmalar, öğrencilerin yorgunluk ve KİSR risklerinin azaltılmasına yönelik çevrimiçi çalışma ortamı ve cihazlarına entegre edilebilecek dijital çözümlere odaklanacaktır. Bu araştırma, pandemi döneminde uzaktan çalışma yapan tüm bireylere, üniversite dışında çevrimiçi eğitim gören farklı eğitim seviyesindeki tüm öğrencilere de uygulanabilir.

\section{Teşekkür}

Anketlere gönüllü olarak katılan üniversite öğrencilerine teșekkür ederiz.

\section{Çıkar Çatışması}

Yazarlar tarafından herhangi bir çıkar çatışması beyan edilmemiştir.

\section{Kaynaklar}

Agomerdah, E.K., Adu Henaku, E., Ayite , D.M.K. ve Apori Ansah, E. (2020). Online Learning in Higher Education During COVID-19 Pandemic: A case of Ghana. Journal of Educational Technology and Online Learning, 3(3), 183202-210.

Alam, A. (basım aşamasında). Challenges and Possibilities of Online Education during Covid19.

Aytar, A., Altintaş, A. ve Aytar, A. (2020). Effects of Posture and Ergonomics Training for Students Receiving Distance Education During the Covid-19 Pandemic on Musculoskeletal Pain, Exercise Behavior Decision-Making Balance, and physical activity level. Exercise Therapy and Rehabilitation ,7(2), 137-144.

Bedir, F., Önal, L. ve Mızrak, O., (2018). Animatörlerin Yorgunluk Hislerinin Mesleki Tutumlarını Etkileme Biçimleri. Atatürk Üniversitesi Beden Eğitimi ve Spor Bilimleri Dergisi, 20(2), 7-16.

Beurskens, A. J. H. M., Bültmann, U., Kant, Ij., Vercoulen, J. H. M. M., Bleijenberg, G. ve Swaen, G. M. H. (2000). Fatigue Among Working People: Validity of a Questionnaire Measure. Occupational and Environmental Medicine, 57(5), 353-357. 
Ergonomics Tips for Working at Home | School of Education. (2020) Erişim adresi: https://www.education.pitt.edu/news-and media/ergonomics-tips-working-home. Erişim tarihi: 19 Nisan 2021.

Cochran, W. G. (1963). Sampling Techniques. Wiley and Sons , New York, USA.

Covid-19 \& Ergonomics: Wait, What?.(2020) Erişim adresi: https://www.assp.org/docs/default-source/psjarticles/cpjunkin_1220.pdf?sfvrsn=412a8c47_2 .Erişim tarihi: 19 Nisan 2021.

Erdinc, O., Hot, K. ve Özkaya, M. (2011). Turkish version of the Cornell Musculoskeletal Discomfort Questionnaire: Cross-cultural Adaptation and Validation. Work, 39(3), 251260.

Ergin, G. (2009). Fizyoterapi programı alan hastalarda yorgunluk ölçeği Checklist Individual Strength (CIS) Questionnaire Türkçe Versiyonunun Geçerliliği. Yüksek Lisans Tezi, Dokuz Eylül Üniversitesi Sağlık Bilimleri Enstitüsü, İzmir.

Ergonomic home study station for students.(2020) Erişimadresi:https://www.thehindubusinessline.com/ companies/covid-19-s-cube-launches- ergonomic-homestudy-station-for students/article32438361.ece. Erişim tarihi: 19 Nisan 2021.

Ergonomics During and After SARS-COV-2 (COVID 19) (2020) Erişim adresi: https://www.assp.org/docs/default-source/covid19/assp_covid 19_ergonomics.pdf?sfvrsn=7b77be47_0. Erișim tarihi: 19 Nisan 2021.

Eroğlu F. ve Kalaycl, N. (2020). Üniversitelerdeki Zorunlu Ortak Derslerden Türk Dili Dersinin Uzaktan ve Yüz Yüze Eğitim Uygulamalarının Karşılaştırılarak Değerlendirilmesi. Ana Dili Eğitimi Dergisi, 8(3) 1001-1027.

Gonzalez, T., De la Rubia, M. A., Hincz, K. P., ComasLopez, M., Subirats, L., Fort, S. ve Sacha, G. M. (2020). Influence of COVID-19 Confinement on Students' Performance in Higher Education. Plos One ,15(10 October), 1-23.

Gupta R, Grover S, Basu A, Krishnan V, Tripathi A, Subramanyam A, Nischal A, Hussain A, Mehra A, Ambekar A, Saha G, Mishra KK, Bathla M, Jagiwala M, Manjunatha N, Nebhinani N, Gaur N, Kumar N, Dalal PK, Kumar P, Midha PK, Daga R, Tikka SK, Praharaj SK, Goyal SK, Kanchan S, Sarkar S, Das S, Sarkhel S, Padhy SK, Sahoo S, Satyanarayana Rao T S, Dubey V, Menon V, Chhabra V, Lahan V ve Avasthi A. Changes in sleep pattern and sleep quality during COVID19 lockdown. Indian J Psychiatry, 62:370-8.
Güzel Özdemir ve Işık, M. (2020). COVID-19 ve Sirkadiyen Ritim. Anatolian Journal of Psychiatry, 20(3), 336.

Global monitoring of school closures. (2020) Erişim adresi:https://en.unesco.org/covid19/educationrespon se/ Erişim tarihi: 19 Nisan 2021

IBM SPSS Statistics for Windows, V. 22. . (2013). Erişim adresi: https://www.ibm.com/trtr/analytics/spss-statistics-software. Erişim tarihi: 19 Nisan 2021.

Ide, D., Tokcalar, O., \& Gunduz, T. (2018). The Effect of Joint Forces and Torques on Speed Variation in Automobile Assembly Lines. Work, 61(2), 211-224.

Kapasia, N., Paul, P., Roy, A., Saha, J., Zaveri, A., Mallick, R. ve Chouhan, P. (2020). Impact of Lockdown on Learning Status of Undergraduate and Postgraduate Students During COVID-19 Pandemic in West Bengal, India. Children and Youth Services Review, 116, 105194.

Kayabinar, E., Kayabinar, B., Önal, B., Zengin, H. Y. ve Köse, N. (2021). The Musculoskeletal Problems and Psychosocial Status of Teachers Giving Online Education During the COVID-19 Pandemic and Preventive Telerehabilitation for Musculoskeletal Problems. Work, 68(1), 33-43.

Keskin, M. ve Özer Kaya, D. (2020). COVID-19 Sürecinde Öğrencilerin Web Tabanlı Uzaktan Eğitime Yönelik Geri Bildirimlerinin Değerlendirilmesi. İzmir Katip Çelebi Üniversitesi Sağlık Bilimleri Fakültesi Dergisi, 5(2), 59-67.

Labrague, L. J. ve Ballad, C. A. (2021). Lockdown Fatigue Among College Students During the Covid-19 Pandemic:Predictive Role of Personal Resilience, Coping Behaviours, and Health. Perspectives in Psychiatric Care, 1-8.

Morin, C. M., Carrier, J., Bastien, C. ve Godbout, R. (2020). Sleep and Circadian Rhythm in Response to the COVID-19 Pandemic. Canadian Journal of Public Health, 111(5), 654-657).

Özkan, N. F. ve Kahya, E. (2017). Bir Üniversitenin İdari Ofislerindeki Ergonomik Risklerin Değerlendirilmesi. Journal of the Faculty of Engineering and Architecture of Gazi University, 32(1), 149-158.

Policy Brief: Education during COVID-19 and beyond. (2020 Erişim adresi: https://www.un.org/development/desa/dspd/wpconten 
t/uploads/sites/22/2020/08/sg_policy_brief_covid19_an d_education_august_2020.pdf. Erişim tarihi: 19 Nisan 2021.

Realyvásquez-Vargas A, Maldonado-Macías AA, Arredondo-Soto KC, Baez-Lopez Y, CarrilloGutiérrez T ve Hernández-Escobedo, G. (2020). The Impact of Environmental Factors on Academic Performance of University Students Taking Online Classes during the COVID-19 Pandemic in Mexico. Sustainability, 12(21), 122.

Sabia, S., Fayosse, A., Dumurgier, Hees, V.T., Paquet, C., Sommelab, A., Kivimaki, M., Dugravot, A., ve Manoux, A.S. (2021) Association of sleep duration in middle and old age with incidence of dementia. Nat Commun, 12, 2289.

Sarı, M., Ünver, B., Kılınç, H.E., Reda Tunç, A. ve Bek N. (2020). Uzaktan Eğitim Sürecinde Bilgisayar Kullanımı ile Üst Ekstemite Etkilemi Arasındaki İlişkinin İncelenmesi.17. Ulusal Türk El ve Üst Ekstremite Cerrahisi Kongresi, s.85,Online.

Sipahioğlu, A. ve Dik, B. (2020). Çalışma Hayatında Yeni Düzen Evden Çalışma Modeline Yönelik Ergonomik Risk Analizi. 2. Uluslararası Endüstriyel ve Çevresel Toksikoloji Kongresi, s.011,0nline.

Soltaninejad, M., Babaei-Pouya, A., Poursadeqiyan, M. ve Arefi, M. F. (2021). Ergonomics Factors Influencing School Education During the COVID-19 Pandemic: A literature review. Work. 68(1), 69-75.

Song, Y., Yang, J., Fei, X., Ma, X. ve Ma, D. (2018). How Does College Students' Online Learning Behavior Impact Their Academic Performance. International Conference on Computer Science and Education,s.591-595

Strielkowski, W.(basım aşamasında). COVID-19 Pandemic and The Digital Revolution in Academia and Higher Education. Preprints.

Şengül, H., Bulut, A. ve Adalan, M. A. (2020). Investigation of The Change of Lockdowns Applied Due to COVID-19 Pandemic on Musculoskeletal Discomfort. Journal of Human Sciences, 17(4), 974-985.

The "coronasomnia" phenomenon keeping you from getting sleep - BBC Worklife. (2021) Erişim adresi: https://www.bbc.com/worklife/article/20210121-thecoronasomnia-phenomenon keeping-us-from-gettingsleep. Erişim tarihi: 19 Nisan 2021.
Wathelet, M., Duhem, S., Vaiva, G., Baubet, T., Habran, E., Veerapa, E., Debien, C., Molenda, S., Horn, M., Grandgenèvre, P., Notredame, C. E. ve D'Hondt, F. (2020). Factors Associated With Mental Health Disorders Among University Students in France Confined During the COVID-19 Pandemic. JAMA network open, 3(10), 1-13.

WHO Timeline - COVID-19.(2020) Erişim adresi: https://www.who.int/news/item/27-04-2020-whotimeline---covid-19. Erişim tarihi: 19 Nisan 2021.

World Population Data. (2020) Erişim adresi: https://www.prb.org/2020-world-population-datasheet/\#: : text=The\%202020\%20Data\%20Sheet\%20iden tifies,2020\%20population\%20of\%207.8\%20billion. Erişim tarihi: 21 Nisan 2021.

Zhu, H., Wei, L. ve Niu, P. (2020). The Novel Coronavirus Outbreak in Wuhan, China. Global Health Research and Policy, 5(1), 1-3. 